\title{
Fort Irwin
}

\section{Integrated Resource Assessment}

\section{Volume 2: Baseline Detail}

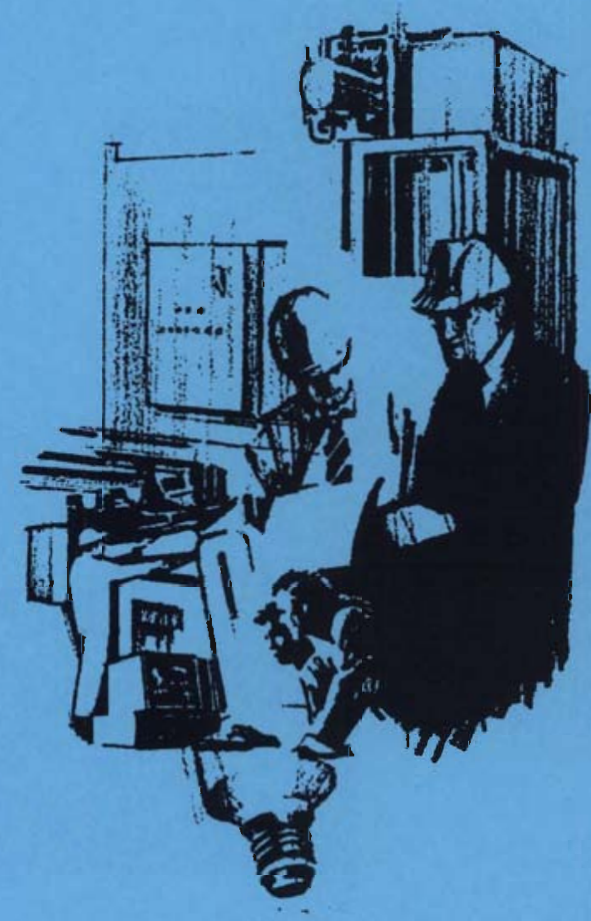

January 1994

Prepared for the U.S. Department of Energy Federal Energy Management Program under Contract DE-AC06-76RLO 1830

Pacific Northwest Laboratory Operated for the U.S. Department of Energy by Battelle Memorial Institute 


\title{
DISCLAIMER
}

This report was prepared as an account of work sponsored by an agency of the United States Government. Neither the United States Government nor any agency thereof, nor Battelle Memorial Institute, nor any of their employees, makes any warranty, expressed or implied, or assumes any legal liability or responsibility for the accuracy, completeness, or usefulness of any information, apparatus, product, or process disclosed, or represents that its use would not infringe privately owned rights. Reference herein to any specific commercial product, process, or service by trade name, trademark, manufacturer, or otherwise does not necessarily constitute or imply its endorsement, recommendation, or favoring by the United States Government or any agency thereof, or Battelle Memorial Institute. The views and opinions of authors expressed herein do not necessarily state or reflect those of the United States Government or any agency thereof.

\author{
PACIFIC NORTHWEST LABORATORY \\ operated by \\ BATTELLE MEMORIAL INSTITUTE \\ for the \\ UNITED STATES DEPARTMENT OF ENERGY \\ under Contract DE-AC06-76RLO 1830
}

\author{
Printed in the United States of America \\ Available to DOE and DOE contractors from the \\ Office of Scientific and Technical Information, P.O. Box 62, Oak Ridge, TN 37831; \\ prices available from (615) 576-8401. FTS 626-8401.
}

Available to the public from the National Technical Information Service, U.S. Department of Commerce, 5285 Port Royal Rd., Springfieid, VA 22161. 


\section{Fort Irwin}

Integrated Resource Assessment

\section{Volume 2: Baseline Detail}

E. E. Richman

J. M. Keller

A. L. Dittmer

D. L. Hadley (Project Manager)

January 1994

Prepared for

the U.S. Department of Energy

Federal Energy Management Program

under Contract DE-AC06-76RLO 1830

Pacific Northwest Laboratory

Richland, Washington 99352 
i 


\begin{abstract}
This report documents the assessment of baseline energy use at Fort Irwin, a U.S. Army Forces Command facility near Barstow, California. It is a companion report to Volume 1, Executive Summary, and Volume 3, Integrated Resource Assessment.

The U.S. Army Forces Command (FORSCOM) has tasked the U.S. Department of Energy (DOE) Federal Energy Management Program (FEMP), supported by the Pacific Northwest Laboratory (PNL), ${ }^{(a)}$ to identify, evaluate, and assist in acquiring all cost-effective energy projects at Fort Irwin. This is part of a model program that PNL has designed to support energy-use decisions in the federal sector. This program 1) identifies and evaluates all cost-effective energy projects; 2) develops a schedule at each installation for project acquisition considering project type, size, timing, and capital requirements, as well as energy and dollar savings; and 3) targets $100 \%$ of the financing required to implement energy efficiency projects. PNL applied this model program to Fort Irwin.

This analysis examines the characteristics of electric, propane gas, and vehicle fuel use for a typical operating year. It records energy-use intensities for the facilities at Fort Irwin by building type and energy end use. It also breaks down building energy consumption by fuel type, energy end use, and building type. A complete energy consumption reconciliation is presented that accounts for all energy use among buildings, utilities, and applicable losses.
\end{abstract}

(a) Pacific Northwest Laboratory is operated for the U.S. Department of Energy by Battelle Memorial Institute under Contract DE-AC06-76RLO 1830. 



\section{Summary}

The U.S. Army Forces Command (FORSCOM) has tasked the U.S. Department of Energy (DOE) Federal Energy Management Program (FEMP), supported by the Pacific Northwest Laboratory (PNL), to identify, evaluate, and assist in acquiring all cost-effective energy projects at Fort Irwin. The FEMP model integrated resource planning (IRP) program is being applied by PNL for federal customers served by Southern California Edison Company (SCE).

This volume, Baseline Detail, documents the baseline energy use at Fort Irwin, a FORSCOM base near Barstow, California. The analysis characterizes electric, propane, and vehicle fuel use for a sample year. It records energy-use intensities for the facilities at Fort Irwin by building type and energy end use. It also breaks down building energy consumption by fuel type, energy end use, and building type. A complete energy consumption reconciliation is presented that includes the accounting of all energy use among buildings, utilities, and applicable losses.

Fort Irwin is a roughly 1,000-square-mile facility situated in the Mojave desert approximately 37 miles northeast of Barstow, California, and south of Death Valley. The main cantonment is located near the southeastern portion of Fort Irwin. The primary mission at Fort Irwin is the operation of the National Training Center (NTC). For energy consumption and billing purposes, the base is divided into three major sectors: commercial, family housing, and on-post utility (including exterior and streetlighting, pumping, and transmission and distribution losses). Of these three sectors, the first two contain non-utility buildings whose energy use is generally correlated with building function and floor area. Table S.1 summarizes the number of buildings and total square feet for each of the areas. The Fort contains 1,574 buildings with a total area of $6,401,436 \mathrm{ft}^{2}$.

Table S.2 summarizes a sample yearly energy consumption and cost for all facilities at Fort Irwin. For each energy type, the yearly total is shown in units appropriate to the energy type and in a common unit as a basis for comparison. The total consumption values represent the sample yearly usage, from the last complete year of data available for each fuel type during this analysis (data were collected for 1991 through 1993). The sample yearly energy consumption is $1,328,876 \mathrm{MBtu}$ at a cost of $\$ 11,856,843$. Electricity accounts for $18.7 \%$ of the usage, propane $16.9 \%$, and transportation fuels (gas, diesel, JP-4, and JP-8) $64.4 \%$. However, electricity accounts for almost $53 \%$ of the total energy cost.

Table S.1. Fort Irwin Building Characterization

\begin{tabular}{||l|c|c|c||}
\hline Energy Use Sector & $\begin{array}{c}\text { Number of } \\
\text { Buildings }\end{array}$ & $\begin{array}{c}\text { Total Floorspace } \\
\left(\mathrm{ft}^{2}\right)\end{array}$ & $\begin{array}{c}\text { Percent of Total } \\
\text { Floorspace }\end{array}$ \\
\hline Commercial & 842 & $3,439,606$ & 53.7 \\
\hline Family Housing & 732 & $2,961,830$ & 46.3 \\
\hline Total & 1,574 & $6,401,436$ & 100.0 \\
\hline
\end{tabular}


Table S.2. Yearly Energy Consumption and Energy Cost at Fort Irwin

\begin{tabular}{||l|c|c|c|c|c||}
\hline $\begin{array}{c}\text { Energy } \\
\text { Type }\end{array}$ & Yearly Total & $\begin{array}{c}\text { Yearly Total } \\
(\mathrm{MBtu})^{(\mathrm{a})}\end{array}$ & $\begin{array}{c}\text { Percent } \\
\text { of Total }\end{array}$ & $\begin{array}{c}\text { Yearly Total } \\
(1993 \$)\end{array}$ & $\begin{array}{c}\text { Percent } \\
\text { of Total }\end{array}$ \\
\hline Electricity & $72,870 \mathrm{MWh}$ & $248,705^{(\mathrm{b})}$ & 18.7 & $6,271,513$ & 52.8 \\
\hline Propane & $2,369,487 \mathrm{gal}$ & $225,101^{(\mathrm{c})}$ & 16.9 & $1,120,293$ & 9.5 \\
\hline Gasoline & $446,098 \mathrm{gal}$ & $55,760^{(\mathrm{d})}$ & 4.2 & 370,261 & 3.1 \\
\hline Diesel & $3,718,042 \mathrm{gal}$ & $516,810^{(\mathrm{e})}$ & 38.9 & $2,491,088$ & 21.0 \\
\hline JP-4 & $770,500 \mathrm{gal}$ & $97,850^{(\mathrm{n})}$ & 7.4 & 577,875 & 4.9 \\
\hline JP-8 & $1,367,750 \mathrm{gal}$ & $184,650^{(\mathrm{s})}$ & 13.9 & $1,025,813$ & 8.7 \\
\hline Totals & & $1,328,876$ & 100.0 & $11,856,843$ & 100.0 \\
\hline $\begin{array}{l}\text { (a) } 1 \mathrm{MBtu}=1,000,000 \mathrm{Btu} . \\
\text { (b) 3,413 Btu/kWh. } \\
\text { (c) } 0.095 \mathrm{MBtu} / \mathrm{gal} . \\
\text { (d) } 0.125 \mathrm{MBtu} / \mathrm{gal} .\end{array}$ \\
\hline
\end{tabular}

Table S.3 presents the energy consumption as derived by the baseline process. Energy use is broken down by energy type and end use - detail that is not available from the total billing data used in Table S.2. The energy in Table S.3 accounts for nearly $100 \%$ of the energy billed in Table S.2. 
Table S.3. Energy Consumption by End Use (MBtu/year)

\begin{tabular}{|c|c|c|c|c|}
\hline Fuel Type/End Use & Commercial & Family Housing & Utility & Total \\
\hline \multicolumn{5}{|l|}{ Electric: } \\
\hline Heating & 1,243 & 0 & 0 & 1,243 \\
\hline Cooling & 28,801 & 29,393 & 0 & 58,194 \\
\hline Vent./Fans & 13,870 & 8,087 & 0 & 21,957 \\
\hline DHW & 565 & 0 & 0 & 565 \\
\hline Cooking & 2,557 & 1,011 & 0 & 3,568 \\
\hline Interior Ltg. & 40,127 & 10,109 & 0 & 50,236 \\
\hline Exterior Ltg. & 7,041 & 1,011 & 0 & 8,052 \\
\hline Refrigeration & 13,548 & 14,152 & 0 & 27,700 \\
\hline Office Eqp. & 4,866 & 0 & $\mathbf{0}$ & 4,866 \\
\hline Other Bldg. End Use & 13,765 & 6,065 & $\mathbf{0}$ & 19,830 \\
\hline Water Supply/Sewage Treatment & 0 & 0 & 26,881 & 26,881 \\
\hline Trans. \& Dist. Losses & 0 & 0 & 13,657 & 13,657 \\
\hline Street Lighting & 0 & 0 & 6,022 & 6,022 \\
\hline Ft. Irwin School & 3,754 & 0 & 0 & 3,754 \\
\hline Trailer Park & 0 & 1,439 & 0 & 1,439 \\
\hline General's Qtrs. & 0 & 70 & $\mathbf{0}$ & 70 \\
\hline Total & 130,137 & 71,337 & 46,560 & 248,035 \\
\hline Percent of Total & $52.5 \%$ & $28.8 \%$ & $18.8 \%$ & $100.0 \%$ \\
\hline \multicolumn{5}{|l|}{ Propane: } \\
\hline Heating & 59,454 & 78,109 & 0 & 137,563 \\
\hline DHW & 11,838 & 31,929 & 0 & 43,767 \\
\hline Cooking & 10,876 & 15,964 & 0 & 26,840 \\
\hline Other Bldg. End Use & 5,703 & 0 & 0 & 5,703 \\
\hline Ft. Irwin School & 11,582 & 0 & 0 & 11,582 \\
\hline Trailer Park & 0 & 217 & 0 & 217 \\
\hline General's Qtrs. & 0 & 107 & 0 & 107 \\
\hline Total & 99,454 & 126,326 & 0 & 225,779 \\
\hline Percent of Total & $44.0 \%$ & $56.0 \%$ & $0.0 \%$ & $100.0 \%$ \\
\hline \multicolumn{5}{|l|}{ Transportation Fuels: } \\
\hline Gasoline & 0 & 0 & 55,762 & 55,762 \\
\hline Diesel & 0 & 0 & 515,692 & 515,692 \\
\hline JP-4 & 0 & 0 & 97,853 & 97,853 \\
\hline JP-8 & 0 & 0 & 184,646 & 184,646 \\
\hline Total & 0 & 0 & 853,954 & 853,954 \\
\hline Percent of Total & $0.0 \%$ & $0.0 \%$ & $100.0 \%$ & $100.0 \%$ \\
\hline Total Energy & 229,591 & 197,663 & 900,514 & $1,327,768$ \\
\hline Percent of Total & $17.3 \%$ & $14.9 \%$ & $67.8 \%$ & $\cdots$ \\
\hline
\end{tabular}




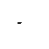

- 


\section{Acknowledgments}

The authors gratefully acknowledge the assistance of several people associated with Fort Irwin Operations that provided us with detailed and timely information that increased the value and usefulness of this analysis. While it is not possible to identify all those who provided assistance, we would like to thank the following individuals who provided helpful support: Rene Quinones, Linda Osborne, Greg Williams, Orvy Dahl, Ben Rodarte, LaSandra Miller, and Ed Rojas.

In addition, the authors thank Randy Wahlstrom, Kate McMordie, and Steve Parker, all of PNL, for their assistance in the collection of data used in this document. The efforts of our editor, Dave Payson, are also gratefully acknowledged.

Eric E. Richman

John M. Keller

Annet L. Dittmer

Don L. Hadley 
- 


\section{Contents}

Abstract $\ldots \ldots \ldots \ldots \ldots \ldots \ldots \ldots \ldots \ldots \ldots \ldots \ldots \ldots \ldots \ldots \ldots \ldots \ldots$ iii

Summary $\quad \ldots \ldots \ldots \ldots \ldots \ldots \ldots \ldots \ldots \ldots \ldots \ldots \ldots \ldots \ldots$

Acknowledgments $\quad \ldots \ldots \ldots \ldots \ldots \ldots \ldots \ldots \ldots \ldots \ldots \ldots \ldots \ldots \ldots \ldots$

Abbreviations and Acronyms $\ldots \ldots \ldots \ldots \ldots \ldots \ldots \ldots \ldots \ldots$

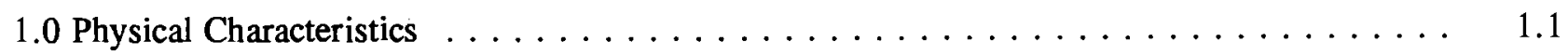

1.1 Site Profile $\ldots \ldots \ldots \ldots \ldots \ldots \ldots \ldots \ldots \ldots \ldots \ldots \ldots \ldots \ldots$

1.2 Building and Facility Profile $\ldots \ldots \ldots \ldots \ldots \ldots \ldots \ldots \ldots \ldots \ldots$

1.2.1 Buildings Characterization $\ldots \ldots \ldots \ldots \ldots \ldots \ldots \ldots \ldots \ldots \ldots \ldots$

1.2.2 Electrical Utility Service Characterization $\ldots \ldots \ldots \ldots \ldots \ldots$

1.2.3 Water and Sewer Service Characterization $\ldots \ldots \ldots \ldots \ldots$

1.2.4 Street and Parking Lot Lighting Characterization $\ldots \ldots \ldots \ldots \ldots$

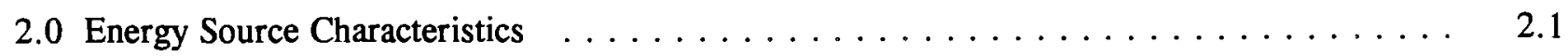

2.1 Electric Supply Source Description $\ldots \ldots \ldots \ldots \ldots \ldots \ldots \ldots \ldots \ldots$

2.2 Propane Supply Source Description $\ldots \ldots \ldots \ldots \ldots \ldots \ldots \ldots \ldots \ldots$

2.3 Transportation Fuel Supply Source Description $\ldots \ldots \ldots \ldots \ldots \ldots \ldots$

3.0 Energy-Use Intensities $\quad \ldots \ldots \ldots \ldots \ldots \ldots \ldots \ldots \ldots \ldots \ldots \ldots \ldots \ldots \ldots \ldots$

3.1 Initial Energy-Use Data Values $\ldots \ldots \ldots \ldots \ldots \ldots \ldots \ldots \ldots \ldots \ldots \ldots$

3.2 Site-Specific Energy Use and Consumption $\ldots \ldots \ldots \ldots \ldots \ldots$

4.0 Electrical Consumption $\ldots \ldots \ldots \ldots \ldots \ldots \ldots \ldots \ldots \ldots \ldots \ldots$

4.1 Metering and Data Summary $\ldots \ldots \ldots \ldots \ldots \ldots \ldots \ldots \ldots$

4.2 Energy-Use Breakdown $\ldots \ldots \ldots \ldots \ldots \ldots \ldots \ldots \ldots \ldots$

4.3 Electrical Demand Summary $\ldots \ldots \ldots \ldots \ldots \ldots \ldots \ldots \ldots \ldots$

5.0 Propane Consumption $\ldots \ldots \ldots \ldots \ldots \ldots \ldots \ldots \ldots \ldots \ldots \ldots \ldots \ldots$ 
5.1 Metering and Data Summary $\ldots \ldots \ldots \ldots \ldots \ldots \ldots \ldots \ldots \ldots \ldots \ldots \ldots$

5.2 Energy-Use Breakdown $\ldots \ldots \ldots \ldots \ldots \ldots \ldots \ldots \ldots \ldots \ldots \ldots \ldots$

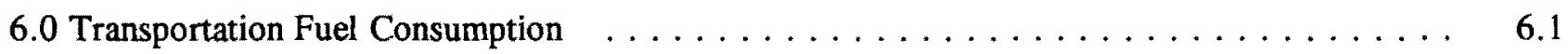

6.1 Metering and Data Summary $\ldots \ldots \ldots \ldots \ldots \ldots \ldots \ldots \ldots \ldots \ldots \ldots \ldots \ldots$

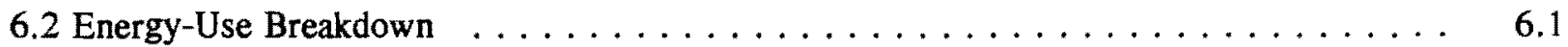

7.0 References $\ldots \ldots \ldots \ldots \ldots \ldots \ldots \ldots \ldots \ldots \ldots \ldots \ldots \ldots \ldots$

7.1 Regional EUI Sources $\ldots \ldots \ldots \ldots \ldots \ldots \ldots \ldots \ldots \ldots \ldots \ldots \ldots \ldots$

Appendix A - Transmission and Distribution System $\ldots \ldots \ldots \ldots \ldots \ldots \ldots \ldots$

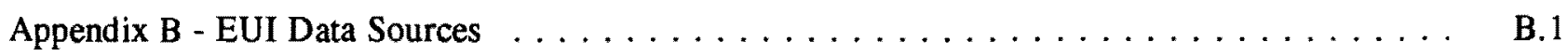

Appendix $\mathrm{C}-$ Building Numbers by Building Type $\ldots \ldots \ldots \ldots \ldots \ldots$ 


\section{Figures}

4.1 Weekday Average Electric Load Profiles $\ldots \ldots \ldots \ldots \ldots \ldots \ldots \ldots \ldots$

4.2 Weekend Average Electric Load Profiles $\ldots \ldots \ldots \ldots \ldots \ldots \ldots \ldots \ldots$

4.3 April Weekday Average Electric Demand by Feeder $\ldots \ldots \ldots \ldots \ldots$

4.4 April Weekend Average Electric Demand by Feeder $\ldots \ldots \ldots \ldots \ldots \ldots$

4.5 June Weekday Average Electric Demand by Feeder $\ldots \ldots \ldots \ldots \ldots$

4.6 June Weekend Average Electric Demand by Feeder $\ldots \ldots \ldots \ldots \ldots \ldots$

4.7 August Weekday Average Electric Demand by Feeder $\ldots \ldots \ldots \ldots \ldots \ldots$

4.8 August Weekend Average Electric Demand by Feeder $\ldots \ldots \ldots \ldots \ldots \ldots$ 


\section{Tables}

S.1 Fort Irwin Building Characterization $\ldots \ldots \ldots \ldots \ldots \ldots \ldots \ldots$

S.2 Yearly Energy Consumption and Energy Cost at Fort Irwin $\ldots \ldots \ldots \ldots$ vi

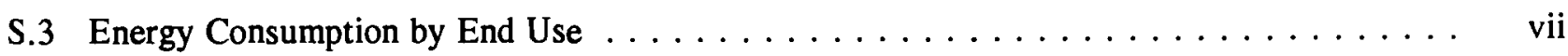

1.1 Fort Irwin Building Type Descriptions $\ldots \ldots \ldots \ldots \ldots \ldots \ldots \ldots \ldots \ldots$

1.2 Fort Irwin Building Characterization $\ldots \ldots \ldots \ldots \ldots \ldots \ldots \ldots \ldots \ldots$

1.3 Ranked List of Building Types at Fort Irwin $\ldots \ldots \ldots \ldots \ldots \ldots \ldots$

1.4 Water Well, Booster, RO, and Sewage Treatment Inventory $\ldots \ldots \ldots \ldots \ldots$

1.5 Street and Parking Lot Lighting at Fort Irwin $\ldots \ldots \ldots \ldots \ldots \ldots$

2.1 Yearly Energy Consumption and Energy Cost at Fort Irwin $\ldots \ldots \ldots \ldots \ldots$

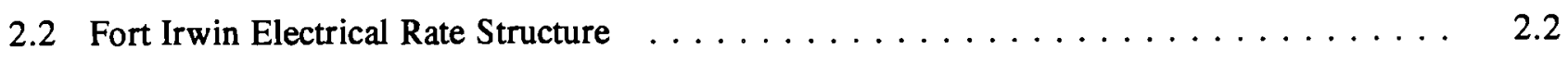

3.1 Fort Irwin-Specific Propane Fuel Energy-Use Intensities $\ldots \ldots \ldots \ldots \ldots$

3.2 Fort Irwin-Specific Electric Energy-Use Intensities $\ldots \ldots \ldots \ldots \ldots \ldots \ldots$

4.1 Fort Irwin Electric Demand and Consumption $-5 / 92$ to $4 / 93 \ldots \ldots \ldots . \ldots$

4.2 Sample Fort Irwin Buildings Electrical Usage $\ldots \ldots \ldots \ldots \ldots \ldots \ldots \ldots$

4.3 Overall Fort Irwin Electric Consumption $\ldots \ldots \ldots \ldots \ldots \ldots \ldots \ldots$

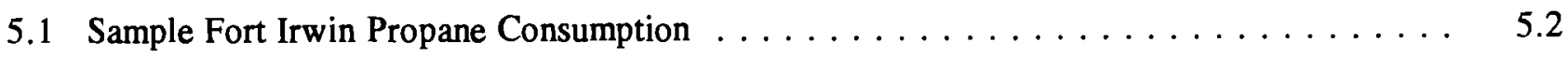

5.2 Overall Fort Irwin Propane Consumption $\ldots \ldots \ldots \ldots \ldots \ldots \ldots$

6.1 Current On-Site Fort Irwin Vehicle Inventory $\ldots \ldots \ldots \ldots \ldots \ldots \ldots \ldots \ldots$

6.2 Sample Fort Irwin Vehicle Fuel Consumption $\ldots \ldots \ldots \ldots \ldots \ldots \ldots$ 


\section{Abbreviations and Acronyms}

\begin{tabular}{|c|c|}
\hline AAFES & Army/Air Force Exchange Service \\
\hline $\mathrm{A} / \mathrm{C}$ & air conditioning \\
\hline AHU & air-handling unit \\
\hline ASD & adjustable speed drive \\
\hline ASHRAE & American Society of Heating, Refrigerating, and Air-Conditioning Engineers, Inc \\
\hline BGP & Burbank, Glendale, Pasedena. \\
\hline BLCC & Building Life-Cycle Cost Program \\
\hline Btu & British thermal unit \\
\hline CBECS & Commercial Building Energy Consumption Survey \\
\hline $\mathrm{CF}$ & compact fluorescent \\
\hline d & day \\
\hline $\mathrm{DEH}$ & Directorate of Engineering and Housing \\
\hline DEIS & Defense Energy Information System \\
\hline DFSC & Defense Fuel Supply Center \\
\hline DHW & domestic hot water \\
\hline DOE & Department of Energy \\
\hline DOD & Department of Defense \\
\hline DOS & disk operating system \\
\hline DSM & demand-side management \\
\hline $\mathrm{EE}$ & energy efficient \\
\hline EEF & energy efficient ballast \\
\hline EEM & energy efficient motor \\
\hline EIA & Energy Information Administration \\
\hline ELC & electronic ballast \\
\hline EMCS & energy management control system \\
\hline EPA & Environmental Protection Agency \\
\hline ERO & energy resource opportunity \\
\hline EUI & energy-use intensity \\
\hline FEMP & Federal Energy Management Program \\
\hline $\mathrm{FO} 2$ & fuel oil No. 2 \\
\hline FORSCOM & Forces Command \\
\hline g & gram \\
\hline gal & gallon \\
\hline h & hour \\
\hline hp & horsepower \\
\hline HPS & high pressure sodium \\
\hline HTHW & high temperature hot water \\
\hline HVAC & heating, ventilation, and air conditioning \\
\hline $\mathrm{Hz}$ & Hertz \\
\hline IES & Illuminating Engineering Society of North America \\
\hline IRA & Integrated Resource Assessment \\
\hline kBtu & thousand British Thermal Unit \\
\hline kcf & thousand cubic feet \\
\hline kVA & kilovolt-amperes \\
\hline KVAR & reactive demand, kilovolt-amperes \\
\hline kW & kilowatt \\
\hline kWh & kilowatt-hour \\
\hline
\end{tabular}




\begin{tabular}{ll} 
LADWP & Los Angeles Department of Water and Power \\
lb & pound \\
LCC & life-cycle cost \\
LED & light emitting diode \\
LPS & low pressure sodium \\
LST & local standard time \\
LTSM & Lighting Technology Screening Matrix \\
M & million \\
mo & month \\
MBtu & million British thermal unit \\
MH & metal halide \\
MW & megawatt \\
MWh & megawatt-hour \\
NBS & National Bureau of Standards \\
NG & natural gas or National Guard \\
NIST & National Institute of Standards and Technology \\
NPV & net present value \\
NTC & National Training Center \\
O\&M & operations and maintenance \\
oF & degrees Fahrenheit \\
PCBs & polychlorinated biphenyls \\
PCF & permanent compact fluorescent \\
PG\&E & Pacific Gas and Electric Company \\
PNL & Pacific Northwest Laboratory \\
psi & pounds per square inch \\
PX & post exchange \\
RECS & Residential Energy Consumption Survey \\
REF & parabolic reflector \\
ROI & return on investment \\
RPL & real property list \\
RTU & rooftop unit \\
rpm & revolutions per minute \\
SCE & Southern California Edison Company \\
SIR & savings to investment ratio \\
V & volt \\
VI & value index \\
W & watt \\
WSCC & Western Systems Coordinating Council \\
WSEO & Washington State Energy Office \\
yr & year \\
\hline
\end{tabular}




\subsection{Physical Characteristics}

\subsection{Site Profile}

Fort Irwin is a roughly 1,000-square mile U.S. Army Forces Command (FORSCOM) facility situated in the Mojave desert approximately 37 miles northeast of Barstow, California, and south of Death Valley. The main cantonment is located near the southeastern portion of Fort Irwin. The primary mission at Fort Irwin is the operation of the National Training Center (NTC). The NTC is a support facility for training of troops normally stationed at other posts throughout the United States. A total of twelve, 28-day training rotations are scheduled each year. The Fort mission results in erratic energy consumption because a large portion of the Fort population is transient, moving on and off-site as dictated by the training schedule.

The climate at Fort Irwin is classified as "high desert," with an average rainfall of 2.5 inches annually, most of which falls between December and February. Summer maximum temperatures are around $104^{\circ} \mathrm{F}$ and winter minimum temperatures are around $29^{\circ} \mathrm{F}$. Annual heating and cooling degree days (base $65^{\circ} \mathrm{F}$ ) are generally equivalent to each other at 2,547 and 2,272 respectively.

\subsection{Building and Facility Profile}

The site facilities at Fort Irwin consist of family housing, commercial, and industrial buildings (that will henceforth be referred to simply as "buildings"), and other real property improvements such as utilities (water, sewer, streetlights, electricity, and LPG), mission-specific facilities (antennas, runways, fuel storage, firing ranges, etc.), outdoor recreation (tennis courts, swimming pools, ballfields, etc.), and other surface improvements (streets, culverts, fences, and parking lots).

\subsubsection{Buildings Characterization}

Roughly 842 commercial buildings (not including school) with an area of 3,439,606 $\mathrm{ft}^{2}$ are reported in the Fort Irwin Real Property Data Base (RPL). There are an additional 732 housing buildings (1636 units not including General's Quarters) with a reported area of $2,961,830 \mathrm{ft}^{2}$, for a total building area of $6,401,436 \mathrm{ft}^{2}$.

Based on the RPL, the facilities at Fort Irwin may be divided into 36 building types. These building types are created by combining facilities of different facility description codes (as provided in the RPL) into larger categories with similar energy usage. This procedure minimizes the number of building types while preserving any unique or unusual building characteristics that have an effect on energy consumption.

The building type codes in Table 1.1 describe the building types at Fort Irwin.

The assignment of a building to a particular building type is based on the Army Facility Code assigned to the building. Buildings with similar facility codes are assigned to particular building types based on similar energy use intensities. (See Section 3 for more detail on the concept of EUIs.) This categorization of buildings is only as good as the data in the RPL. As buildings are vacated and occupied by new tenants, the numbers of buildings and square footage associated with each category may change. Similarly, the assigned category codes are taken to be correct and representative of actual function. One group of buildings that is not included in the building reconciliation (also not found in the RPL) is that of the public school facilities. The 36 types shown represent the best estimate of Fort Irwin building types at 
Table 1.1. Fort Irwin Building Type Descriptions

\begin{tabular}{|c|c|}
\hline Bldg Type & Description \\
\hline ADMIN & Administration Building \\
\hline ADMIN-MT & Administration Building (manufactured trailer type) \\
\hline BRK/ADM & Barracks (enlisted \& BOQ) \\
\hline CHAPEL & Chapel \\
\hline CLINIC & Medical Facility Other Than Hospital \\
\hline CLUB & Club (NCO, Officers, etc.) \\
\hline COMCATN & Communications \\
\hline DET-RR & Detached Restrooms, Latrines, Shower Houses, etc. \\
\hline DGR & Dry Goods/Retail \\
\hline DINING & Enlisted Dining Facility \\
\hline FUELDSP & Fuel Dispensing Bldgs. \\
\hline GROCERY & Grocery \\
\hline HANGAR & Hangar \\
\hline HOSPITL & Hospital \\
\hline HOTEL & Hotel/Motel/Guesthouse \\
\hline HSG-FAM & Family Housing \\
\hline HUT & Misc. Small Bldgs. and Shelters (not security) \\
\hline LAB-MED & Laboratory/Vet. Facility \\
\hline MTRPOOL & Maint. Shops for Cars, Trucks, Tanks - Land Vehicles \\
\hline MWR & Morale, Welfare, \& Recreation (Non-Physical Rec) \\
\hline OTHER & Other (generally low energy use bldgs.) \\
\hline PLT-BLDG & Heating/Cooling/Power Plant, Elec. Distribution Buildings \\
\hline POOL-OT & Outdoor Swimming Pools \\
\hline PUMP & Pump Bldgs. - Sewer, Wells, Wash Platforms, etc. \\
\hline REC & Physical Recreation (gym, bowling alley, etc.) \\
\hline RESTRNT & Food Service Facility (non-dining hall) \\
\hline SECURTY & Security Operations (police, fire) \\
\hline SHOP & General Maint. Shops, inc. DEH/Base Eng. \\
\hline
\end{tabular}


Table 1.1. (contd)

\begin{tabular}{||l|l||}
\hline \multicolumn{1}{|c||}{ Bldg Type } & \multicolumn{1}{c|}{ Description } \\
\hline SHOP-AIR & Maint. Shops for Cooling Equipment \\
\hline SHOP-ELC & Maint. Shops for Electronic Equipment \\
\hline SHOP-HVY & Maint. Shops with Heavy Eqp.- Plating, Welding, Railroad \\
\hline SHOP-WPN & Maint. Shops for Weapons, from Pistols to ICBMs \\
\hline STOR-UH & Unheated Storage (vehicles, ammo, residential sheds) \\
\hline TRAING & Training/Classrooms (not simulator) \\
\hline WHS & Warehouse \\
\hline WHS-CLD & Cold Storage Warehouse \\
\hline
\end{tabular}

this time. In Table 1.2, the building types are applied to the Fort Irwin RPL to describe each building type in terms of energy type, building count, total floor space, and percent of total floor space. Appendix C contains a list of building numbers in each building type.

There is considerable expansion occurring at Fort Irwin. A new 172-unit housing area is currently under construction, a 220-unit family housing area is planned for FY94, and several new modular office buildings have recently been added. The energy consumption and EUI estimates in this report are only for facilities currently listed in the RPL. While some of the new facilities are similar to existing buildings, changes in building constuction codes and equipment efficiency standards may make it difficult to extrapolate the data to new facilities.

Table 1.3 shows the list of building types at Fort Irwin ranked by square footage. Family housing is the single largest category by square footage at Fort Irwin, followed by barracks, administration, motor pools, warehouses, manufactured-trailer administration, and general shops. These building types account for over $80 \%$ of the total building stock at Fort Irwin. Because of the different energy use intensities (EUIs) in each building type, building types with greater square footage do not necessarily consume more energy. Section 3 discusses the concept of EUIs in greater detail, and Sections 4 and 5 discuss the total energy usage by the various building types.

Commercial buildings are a mix of older wood frame construction and newer stone/brick construction, with some metal frame and curtain wall construction. Family housing is primarily wood frame construction with varying levels of insulation in the walls or ceilings.

\subsubsection{Electrical Utility Service Characterization}

Electrical service to Fort Irwin is provided by Southern California Edison (SCE). Distribution on the site consists of five 12-kV transmission lines from the "old" and "new" substations. Line \#3 serves barracks facilities, field training areas, and the area out to the sewage treatment plant. Line \#4 covers a majority of the family housing areas as well as some barracks and personnel support facilities. Line \#5 accounts for the remaining family housing and some support facilities. Line \#6/8 serves older barracks, 
Table 1.2. Fort Irwin Building Characterization

\begin{tabular}{|c|c|c|c|c|c|}
\hline $\begin{array}{c}\text { Building } \\
\text { Type }\end{array}$ & $\begin{array}{c}\text { Energy } \\
\text { Type }\end{array}$ & $\begin{array}{l}\text { Number of } \\
\text { Buildings }\end{array}$ & $\begin{array}{c}\text { Total } \\
\text { Floorspace } \\
\left(\mathrm{ft}^{2}\right)\end{array}$ & $\begin{array}{c}\text { Average } \\
\text { Floorspace } \\
\left(\mathrm{ft}^{2}\right)\end{array}$ & $\begin{array}{l}\text { Percent of } \\
\text { Base Total } \\
\text { Floorspace }\end{array}$ \\
\hline ADMIN & $\mathrm{E} / \mathrm{P}$ & 77 & 362,029 & 4,702 & 6 \\
\hline ADMIN-MT & $E / P$ & 59 & 275,376 & 4,667 & 4 \\
\hline BRK/ADM & $E / P$ & 67 & 760,148 & 11,345 & 12 \\
\hline CHAPEL & $\mathrm{E} / \mathrm{P}$ & 4 & 23,614 & 5,904 & $<1$ \\
\hline CLINIC & $\mathrm{E} / \mathrm{P}$ & 8 & 25,310 & 3,164 & $<1$ \\
\hline CLUB & $E / P$ & 9 & 67,429 & 7,492 & 1 \\
\hline COMCATN & $\mathrm{E} / \mathrm{P}$ & 8 & 5,695 & 712 & $<1$ \\
\hline DET-RR & $\mathrm{E} / \mathrm{P}$ & 26 & 17,644 & 679 & $<1$ \\
\hline DGR & $E / P$ & 14 & 114,662 & 8,190 & 2 \\
\hline DINING & $E / P$ & 3 & 35,939 & 11,980 & 1 \\
\hline FUELDSP & $\mathrm{E} / \mathrm{P}$ & 34 & 64,715 & 1,903 & 1 \\
\hline GROCERY & $\mathrm{E} / \mathrm{P}$ & 1 & 56,500 & 56,500 & 1 \\
\hline HANGAR & $\mathrm{E} / \mathrm{P}$ & 5 & 82,520 & 16,504 & 1 \\
\hline HOSPITL & $E / P$ & 1 & 63,818 & 63,818 & 1 \\
\hline HOTEL & $\mathrm{E} / \mathrm{P}$ & 7 & 11,566 & 1,652 & $<1$ \\
\hline HSG-FAM & $\mathrm{E} / \mathrm{P}$ & 732 & $2,961,830$ & 4,046 & 46 \\
\hline HUT & - & 90 & 152,478 & 1,694 & 2 \\
\hline LAB-MED & $E / P$ & 2 & 9,415 & 4,708 & $<1$ \\
\hline MTRPOOL & $\mathrm{E} / \mathrm{P}$ & 30 & 309,890 & 10,330 & 5 \\
\hline MWR & $\mathrm{E} / \mathrm{P}$ & 20 & 125,854 & 6,293 & 2 \\
\hline OTHER & $E / P$ & 1 & 1,536 & 1,536 & $<1$ \\
\hline PLT-BLDG & $\mathrm{E} / \mathrm{P}$ & 18 & 12,366 & 687 & $<1$ \\
\hline POOL-OT & $\mathrm{E} / \mathrm{P}$ & 3 & 7,727 & 2,576 & $<1$ \\
\hline PUMP & $\mathrm{E}$ & 22 & 10,976 & 499 & $<1$ \\
\hline REC & $E / P$ & 4 & 62,016 & 15,504 & 1 \\
\hline RESTRNT & $E / P$ & 2 & 4,712 & 2,356 & $<1$ \\
\hline
\end{tabular}


Table 1.2. (contd)

\begin{tabular}{||l|c|c|c|c|c||}
\hline $\begin{array}{c}\text { Building } \\
\text { Type }\end{array}$ & $\begin{array}{c}\text { Energy } \\
\text { Type }\end{array}$ & $\begin{array}{c}\text { Number of } \\
\text { Buildings }\end{array}$ & $\begin{array}{c}\text { Total } \\
\text { Floorspace } \\
\left(\mathrm{ft}^{2}\right)\end{array}$ & $\begin{array}{c}\text { Average } \\
\text { Floorspace } \\
\left(\mathrm{ft}^{2}\right)\end{array}$ & $\begin{array}{c}\text { Percent of } \\
\text { Base Total } \\
\text { Floorspace }\end{array}$ \\
\hline \hline SECURTY & E/P & 12 & 17,498 & 1,458 & $<1$ \\
\hline SHOP & E/P & 10 & 189,273 & 18,927 & 3 \\
\hline SHOP-AIR & E/P & 1 & 2,000 & 2,000 & $<1$ \\
\hline SHOP-ELC & E/P & 5 & 22,684 & 4,537 & $<1$ \\
\hline SHOP-HVY & E/P & 1 & 3,200 & 3,200 & $<1$ \\
\hline SHOP-WPN & E/P & 1 & 8,022 & 8,022 & $<1$ \\
\hline STOR-UH & - & 222 & 157,442 & 709 & 2 \\
\hline TRAING & E/P & 29 & 72,959 & 2,516 & 1 \\
\hline WHS & E/P & 45 & 288,093 & 6,402 & 5 \\
\hline WHS-CLD & E/P & 1 & 14,500 & 14,500 & $<1$ \\
\hline \hline Totals & & 1,574 & $6,401,436$ & & 100 \\
\hline Notes: E: Electricity, P: Propane & & & \\
\hline \hline
\end{tabular}

trailer spaces, support facilities, large maintenance shops, and other industrial areas. Line $\# 7 / 9$ covers the remaining older barracks and support facilities. The "new" substation was built to accommodate the planned expansion of the family housing areas. Accordingly, lines \#4 and \#5 are fed from the "new" substation; the remaining three lines are fed from the "old" substation. Both the transmission and distribution systems are overhead line systems for most of the commercial areas. A majority of the family housing areas are supplied by underground lines.

There are approximately 610 transformers at Fort Irwin, with a total estimated nameplate capacity of over 35,000 kVA. The losses associated with the operation of these transformers are estimated at an average level of $272 \mathrm{~kW}$, for a total yearly loss of 2,382 MWh. Details of the methodology and Fort Irwin-specific calculations for transmission and distribution system losses can be found in Appendix A of this report.

\subsubsection{Water and Sewer Service Characterization}

Water is provided to Fort Irwin by eleven operating wells and six booster pumps. Eight of the wells are located in and around the main commercial area. The remaining three wells are to the northeast towards the Bicycle Lake Basin. The aggregate capacity of the well pumps is $4,595 \mathrm{gpm}$, with an aggregated load of 1,040 horsepower. Booster pumps are also in operation with each of the well systems at a total effective load of approximately 1,050 horsepower. 
Table 1.3. Ranked List of Building Types at Fort Irwin

\begin{tabular}{||l|c|c|c||}
\hline $\begin{array}{c}\text { Building } \\
\text { Type }\end{array}$ & $\begin{array}{c}\text { Total Area } \\
\left(\mathrm{ft}^{2}\right)\end{array}$ & $\begin{array}{c}\text { Percent } \\
\text { Area }\end{array}$ & $\begin{array}{c}\text { Cumulative } \\
\text { Percent Area }\end{array}$ \\
\hline HSG-FAM & $2,961,830$ & 46 & 46 \\
\hline BRK/ADM & 760,148 & 12 & 58 \\
\hline ADMIN & 362,029 & 6 & 64 \\
\hline MTRPOOL & 309,890 & 5 & 69 \\
\hline WHS & 288,093 & 5 & 74 \\
\hline ADMIN-MT & 275,376 & 4 & 78 \\
\hline SHOP & 189,273 & 3 & 81 \\
\hline STOR-UH & 157,442 & 2 & 83 \\
\hline HUT & 152,478 & 2 & 85 \\
\hline MWR & 125,854 & 2 & 87 \\
\hline DGR & 114,662 & 2 & 89 \\
\hline HANGAR & 82,520 & 1 & 90 \\
\hline TRAING & 72,959 & 1 & 91 \\
\hline CLUB & 67,429 & 1 & 92 \\
\hline FUELDSP & 64,715 & 1 & 93 \\
\hline ALL OTHER & 416738 & $<1 \mathrm{EACH}$ & 100 \\
\hline
\end{tabular}

In addition to the well and booster pump system, demineralized water is also produced for use at the Fort. This is supplied to all occupied facilities through a separate distribution system. Demineralization is accomplished at the Reverse Osmosis (RO) Plant. The current major aggregate load of the equipment at the RO plant is approximately 255 horsepower.

Sewage treatment for Fort Irwin is provided by an on-site system. This includes the treatment of sewage for the central Fort Irwin facilities and family housing. The current major aggregate load of the equipment at the sewage treatment plant is approximately 210 horsepower.

Table 1.4 provides an inventory of the various water wells, boosters, $\mathrm{RO}$ and sewage treatment equipment at Fort Irwin. The table includes estimated operating hours and consumption (in $\mathrm{MWh}$ ) for a sample operating year. Consumption data are based on capacity and "run-time" information supplied by Fort Irwin personnel and assumptions of typical operating characteristics. 
Table 1.4. Water Well, Booster, RO, and Sewage Treatment Inventory

\begin{tabular}{|c|l|r|r|r||}
\hline $\begin{array}{c}\text { Bldg. } \\
\text { Number }\end{array}$ & \multicolumn{1}{|c|}{$\begin{array}{c}\text { Bldg. } \\
\text { Description }\end{array}$} & $\begin{array}{c}\text { Pump Motor } \\
\text { Horsepower }\end{array}$ & $\begin{array}{c}\text { Annual } \\
\text { Run Hours }\end{array}$ & $\begin{array}{c}\text { Estimated } \\
\text { Annual MWh }\end{array}$ \\
\hline 00042 & RO Plant & 15 & 4,000 & 60 \\
\hline 00042 & RO Plant & 15 & 4,000 & 60 \\
\hline 00043 & RO Plant & 75 & 3,000 & 225 \\
\hline 00044 & RO Plant & 75 & 8,760 & 657 \\
\hline 00044 & RO Plant & 75 & 8,760 & 657 \\
\hline 00149 & Well I-3 & 60 & 1,820 & 109 \\
\hline 00319 & Well I-5 & 75 & 3,028 & 227 \\
\hline 00386 & Well I-6 & 60 & 3,420 & 205 \\
\hline 00663 & Well I-7 & 200 & 3,024 & 605 \\
\hline 00700 & Sewage Plant & 25 & 4,000 & 100 \\
\hline 00700 & Sewage Plant & 25 & 4,000 & 100 \\
\hline 00700 & Sewage Ponds & 40 & 8,760 & 350 \\
\hline 00700 & Sewage Ponds & 40 & 8,760 & 350 \\
\hline 00700 & Sewage Ponds & 40 & 8,760 & 350 \\
\hline 00700 & Sewage Ponds & 40 & 8,760 & 350 \\
\hline 05990 & Booster \#1 & 200 & 1,104 & 221 \\
\hline 05990 & Booster \#2 & 200 & 873 & 175 \\
\hline 05990 & Booster \#3 & 200 & 1,544 & 309 \\
\hline 05994 & Bicycle Lake Well \#2 & 60 & 344 & 21 \\
\hline 05996 & Bicycle Lake Well \#4 & 100 & 3,262 & 326 \\
\hline 05997 & Bicycle Lake Well \#5 & 125 & 2,441 & 305 \\
\hline 05998 & Bicycle Lake Well \#1 & 30 & 2,594 & 186 \\
\hline 18000 & Langford Booster Stn. & 150 & 3,052 & 389 \\
\hline 18000 & Langford Booster Stn. & 150 & 1,506 & 458 \\
\hline 18000 & Langford Booster Stn. & 3,195 & 226 \\
\hline 18003 & Langford Well \#2 & 3,590 & 320 \\
\hline 18005 & Langford Well \#1 & 146 & 449 \\
\hline 18005 & Langford Well \#3 & & & 8676 \\
\hline Totals: & & 150 & \\
\hline
\end{tabular}

\subsubsection{Street and Parking Lot Lighting Characterization}

Exterior street and parking lot lighting at Fort Irwin is comprised of a variety of lighting types and capacities including High Pressure Sodium (HPS), Mercury Vapor (Mercury), and Metal Halide (MH). Accurate records of quantities and capacities were not available from Fort sources. A manual lighting count was completed that included all street and parking lot lights in and around the main cantonment. Also included in the count were the perimeter lights at the ordinance storage area. This count along with 
some lamp procurement information collected at the Fort was used to estimate street and parking lot ighting energy consumption. Table 1.5 provides details on the quantities, estimated types and consumption of street and parking lot lighting at Fort Irwin.

The total streetlighting demand was calculated to be $483 \mathrm{~kW}$. Assuming a conservative 10 hours of operation per day (many will operate longer but some are only used during specific activity), this is equivalent to a total of 1,764 MWh per year. Streetlighting technology consists primarily of High Pressure Sodium (1,041), some Mercury Vapor (79) and a few Metal Halide (9).

Table 1.5. Street and Parking Lot Lighting at Fort Irwin

\begin{tabular}{||l|r|r|r|r||}
\hline $\begin{array}{c}\text { Lamp } \\
\text { Type }\end{array}$ & $\begin{array}{c}\text { Nominal } \\
\text { Lamp } \\
\text { Wattage }\end{array}$ & $\begin{array}{c}\text { Total } \\
\text { Fixture } \\
\text { Wattage }\end{array}$ & $\begin{array}{c}\text { Estimated } \\
\text { Fixture } \\
\text { Quantity }\end{array}$ & $\begin{array}{c}\text { Estimated } \\
\text { Annual } \\
\text { MWh }\end{array}$ \\
\hline HPS & 1,000 & 1,100 & 72 & 286 \\
\hline HPS & 400 & 465 & 505 & 857 \\
\hline HPS & 250 & 305 & 459 & 511 \\
\hline HPS & 200 & 240 & 5 & 4 \\
\hline Mercury & 750 & 790 & 15 & 42 \\
\hline Mercury & 400 & 460 & 1 & 2 \\
\hline Mercury & 250 & 294 & 25 & 27 \\
\hline Mercury & 175 & 210 & 14 & 11 \\
\hline Mercury & 150 & 170 & 24 & 15 \\
\hline MH & 1,000 & 1,080 & 1 & 2 \\
\hline MH & 250 & 294 & 1 & 1 \\
\hline MH & 175 & 210 & & 7 \\
\hline Totals: & & & 1,128 & 1,764 \\
\hline Lamp Counts: & HPS & 1,041 & \\
MH & & 9 & \\
\hline \hline
\end{tabular}




\subsection{Energy Source Characteristics}

Energy sources used by Fort Irwin include electricity, propane, and transportation fuels (gas, diesel, JP-4 and JP-8). Fuel oil is used in small quantities (primarily for backup generator systems) and is not considered in this assessment. Table 2.1 shows a summation of the sample annual energy consumption and cost at Fort Irwin for all facilities including family housing. For each energy type, the yearly total is shown in units appropriate to the energy as well as a common unit as a basis of comparison. The total consumption values are based on the usage values chosen for analysis in this report as typical current yearly usage. This sample year is based on the best available data gathered from 1991 through 1993 consumption levels. These are aggregations of various billing consumption amounts and are considered representative of normal Fort Irwin operational energy consumption.

\subsection{Electric Supply Source Description}

Electricity is supplied to Fort Irwin by Southern California Edison (SCE) and delivered to the Tiefort Terminal Station via a $115-\mathrm{kV}$ transmission line. A sub-transmission line rated at $34.5-\mathrm{kV}$ connects this station to the Fort Irwin substations. Fort Irwin is supplied under rate schedule TOU-8, with an additional incremental sales rate agreement covering additional electricity usage above pre-set limits.

The rate structure applicable to Fort Irwin (from the June 1993 bill) is shown in Table 2.2. The existing incremental sales rate (ISR) is very low. However, in 1997, Fort Irwin will no longer be eligible for the ISR and it is assumed that the Fort will revert to the base TOU-8 rate. This will increase the Fort's annual electric bill by approximately $\$ 700,000$ (based on May 1992 through June 1993 consumption and the current TOU-8 rate).

Table 2.1. Yearly Energy Consumption and Energy Cost at Fort Irwin

\begin{tabular}{|c|c|c|c|c|c|}
\hline $\begin{array}{l}\text { Energy } \\
\text { Type }\end{array}$ & Yearly Total & $\begin{array}{l}\text { Yearly Total } \\
(\mathrm{MBtu})^{(\mathbf{a})}\end{array}$ & $\begin{array}{l}\text { Percent } \\
\text { of Total }\end{array}$ & $\begin{array}{c}\text { Yearly Total } \\
(1993 \$)\end{array}$ & $\begin{array}{l}\text { Percent } \\
\text { of Total }\end{array}$ \\
\hline Electricity & $72,870 \mathrm{MWh}$ & $248,705^{(\mathrm{b})}$ & 18.7 & $6,271,513$ & 52.8 \\
\hline Propane & $2,369,487 \mathrm{gal}$ & $225,101^{(\mathrm{c})}$ & 16.9 & $1,120,293$ & 9.5 \\
\hline Gasoline & $446,098 \mathrm{gal}$ & $55,760^{(\mathrm{d})}$ & 4.2 & 370,261 & 3.1 \\
\hline Diesel & $3,718,042 \mathrm{gal}$ & $516,810^{(e)}$ & 38.9 & $2,491,088$ & 21.0 \\
\hline $\mathrm{JP}-4$ & $770,500 \mathrm{gal}$ & $97,850^{(f)}$ & 7.4 & 577,875 & 4.9 \\
\hline JP-8 & $1,367,750 \mathrm{gal}$ & $184,650^{(8)}$ & 13.9 & $1,025,813$ & 8.7 \\
\hline Totals & & $1,328,876$ & 100.0 & $11,856,843$ & 100.0 \\
\hline \multicolumn{6}{|c|}{$\begin{array}{l}\text { (a) } 1 \mathrm{MBtu}=1,000,000 \mathrm{Btu} . \\
\text { (b) } 3,413 \mathrm{Btu} / \mathrm{kWh} . \\
\text { (c) } 0.095 \mathrm{MBtu} / \mathrm{gal} . \\
\text { (d) } 0.125 \mathrm{MBtu} / \mathrm{gal} .\end{array}$} \\
\hline
\end{tabular}


Table 2.2. Fort Irwin Electrical Rate Structure (July 1992)

\begin{tabular}{|c|c|c|}
\hline Rate Periods & Summer & Winter \\
\hline & $\begin{array}{l}\text { (first Sunday in June - } \\
\text { first Sunday in October) }\end{array}$ & $\begin{array}{l}\text { (first Sunday in October - } \\
\text { first Sunday in June) }\end{array}$ \\
\hline Peak & $12: 00$ noon to $6: 00 \mathrm{PM}(\mathrm{M}-\mathrm{F})$ & NA \\
\hline Mid-Peak & $\begin{array}{l}\text { 8:00 AM to } 12: 00 \text { noon }(M-F) \\
\text { 6:00 PM to 11:00 PM (M-F) }\end{array}$ & 8:00 AM to 9:00 PM (M-F) \\
\hline Off-Peak & \multicolumn{2}{|c|}{ All other hours not listed plus all day on weekends and holidays } \\
\hline Super Off-Peak & NA & $12: 00$ midnight to $6: 00 \mathrm{PM}$ \\
\hline \multicolumn{3}{|l|}{ Base Rates: } \\
\hline Charge & Summer & Winter \\
\hline $\begin{array}{l}\text { Demand Charges (per } \mathrm{kW} \text { ) } \\
\text { Non-Time Related: } \\
\text { Maximum Peak Demand (not less than } \\
50 \% \text { of previous } 11 \text { months }\end{array}$ & $\$ 3.15$ & $\$ 3.15$ \\
\hline $\begin{array}{l}\text { Time Related: } \\
\text { Maximum Peak Period Demand } \\
\text { Maximum Mid-Peak Period Demand } \\
\text { Maximum Off-Peak Period Demand }\end{array}$ & $\begin{array}{l}\$ 15.75 \\
\$ 2.35 \\
\$ 0.00\end{array}$ & $\begin{array}{l}\text { NA } \\
\$ 0.00 \\
\$ 0.00\end{array}$ \\
\hline $\begin{array}{l}\text { Energy Charges (per kWh) } \\
\text { Peak Period } \\
\text { Mid-Peak Period } \\
\text { Off-Peak Period }\end{array}$ & $\begin{array}{l}\$ 0.13752 \\
\$ 0.06517 \\
\$ 0.04077\end{array}$ & $\begin{array}{l}\text { NA } \\
\$ 0.07688 \\
\$ 0.04335\end{array}$ \\
\hline Power Factor Adjustment (per kVAR) & $\$ 0.25$ & $\$ 0.25$ \\
\hline Peak Period Rate Limiter (per kWh) & $\$ 1.07244$ & NA \\
\hline Peak Period Ave. Rate Limiter (per kWh) & $\$ 0.17759$ & NA \\
\hline Customer Charge (per meter per month) & $\$ 359.45$ & $\$ 359.45$ \\
\hline \multicolumn{3}{|c|}{ Incremental Rates: (applicable to all consumption above base levels) } \\
\hline \multicolumn{3}{|c|}{ Base Levels: } \\
\hline Demand Levels (ave. monthly base level kW) & Summer & Winter \\
\hline $\begin{array}{l}\text { On-Peak } \\
\text { Mid-Peak } \\
\text { Off-Peak } \\
\text { Super Off-Peak } \\
\text { Non-Time Related }\end{array}$ & $\begin{array}{c}11,512 \\
10,856 \\
9,552 \\
\text { NA } \\
11,512\end{array}$ & $\begin{array}{c}\text { NA } \\
8,812 \\
7,576 \\
7,576 \\
8,812 \\
\end{array}$ \\
\hline \multicolumn{3}{|l|}{ Consumption Levels (ave. monthly usage kWh) } \\
\hline $\begin{array}{l}\text { On-Peak } \\
\text { Mid-Peak } \\
\text { Off-Peak } \\
\text { Super Off-Peak }\end{array}$ & $\begin{array}{l}1,208,044 \\
1,646,208 \\
2,710,710 \\
\text { NA }\end{array}$ & $\begin{array}{c}\text { NA } \\
1,862,044 \\
1,745,326 \\
2,296,481\end{array}$ \\
\hline Charge & \multicolumn{2}{|c|}{ All Year. } \\
\hline Demand Charges (per kW above base level) & \multicolumn{2}{|c|}{$\begin{array}{l}\text { Avoided Cost plus } \$ 1.00 \text { per Summer On-Peak kW (rate varies } \\
\text { with each rate period) }\end{array}$} \\
\hline Energy Charges (per kWh) & \multicolumn{2}{|c|}{$\begin{array}{l}\text { Avoided Cost plus } \$ 0.02 \text { per } \mathrm{kWh} \text { (rate varies with each rate } \\
\text { period) }\end{array}$} \\
\hline Public Utilities Commission (PUC) and Low Income & \multicolumn{2}{|l|}{ As determined } \\
\hline
\end{tabular}




\subsection{Propane Supply Source Description}

Propane is supplied to Fort Irwin through a competitive contract and delivered to a central propane storage area consisting of four 30,000-gallon tanks. The propane is distributed through 8-, 6-, 4-, and 2inch lines throughout the Fort and is used primarily for heating, cooking, and water heating. The current propane rate is 47.3 cents per gallon.

\subsection{Transportation Fuel Supply Source Description}

Fuels for vehicle use are supplied to Fort Irwin by various contract suppliers and stored at point-of-use locations in commercial areas. The primary fuels are gasoline, diesel, JP-4 (aviation fuel) and JP-8 (combination aviation/ground fuel). Current fuel prices (\$/gal.) are gasoline at $\$ 0.83$, diesel at $\$ 0.67, \mathrm{JP}-4$ at $\$ 0.75$, and JP-8 at $\$ 0.75$. 


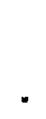




\subsection{Energy-Use Intensities}

Energy-use intensities (EUI) are defined as energy-use per unit floor area, per unit time and are commonly expressed as thousands of Btu per square foot per year $\left(\mathrm{kBtu} / \mathrm{ft}^{2}\right.$-year), or kilowatt hours per square foot per year $\left(\mathrm{kWh} / \mathrm{ft}^{2}\right.$-year). These EUI values are used to help develop baseline consumption for various building types when actual consumption data are not available. This section describes the EUI information that was used in the energy assessment at Fort Irwin.

The specific EUI values used in the Fort Irwin baseline assessment are derived from three primary data sources. The first is regional information collected from local utilities and other energy organizations that have prepared EUI data for their own and public use. The second is the PNL experience gained from analyzing EUI data at other federal sites, including military facilities. The similarity of military facilities from site to site, coupled with appropriate adjustments for climate and operational differences between the sites, provides valuable EUI information. These two sources make up the initial set of EUI values that are used as a starting point for determining appropriate EUI values.

The third and most accurate source of EUI data is actual metered and/or billing information obtained at the site itself. Since this information is usually scarce for a large sample of facilities at the site, the regional and previous site EUI values are relied upon for much of the assessment. Adjusting the data from these three data sources provides the means to derive a specific set of EUI values for the various buildings types and end uses at Fort Irwin.

\subsection{Initial Energy-Use Data Values}

Initial EUI values are used as a starting point to determine appropriate EUI values in the absence of specific data. The regional and local EUI data make up part of the initial EUI values and were collected from six sources that include Pacific Gas \& Electric (PG\&E), Southern California Edison (SCE), Los Angeles Department of Water \& Power (LADWP), California Energy Commission data for Burbank, Glendale, and Pasadena (BGP), data from the Environmental Protection Agency Western Systems Coordinating Council (EPA/WSCC), and the Energy Information Administration's Commercial Buildings Energy Consumption Survey (CBECS). (Complete references are included in the bibliography.)

Tables B.1-B.24 (located in Appendix B) break out energy use by facility type, building type, fuel type, and fuel end use by data source. The two major building type categories are residential and commercial. Energy use is expressed in $\mathrm{kWh} / \mathrm{ft}^{2}$-year for electric EUIs and $\mathrm{kBtu} / \mathrm{ft}^{2}$-year for fossil fuel EUIs. Energyuse data are reported for the following end use categories: space heating, cooling, domestic hot water (DHW), cooking, refrigeration, interior and exterior lighting, office equipment, and other. The other category includes miscellaneous end uses like electrical appliances, motors, and water/steam heating for laundry or food preparation.

In the residential category, data were available only as unit energy consumption (UEC) values, given in units of $\mathrm{kWh} /$ year per dwelling unit. To convert a UEC to an EUI, an average residential square foot value must be assumed. For this assessment, values of $1,500 \mathrm{ft}^{2}$ for a single family residence and $1,000 \mathrm{ft}^{2}$ for a multi-family residential unit were assumed based on CBECS data. These EUI values were used as a starting point for the analysis of Fort Irwin. 
While some of the EUI values correlate well from source to source for a given building type, fuel type, and end use, others do not. There are a number of reasons for discrepancies, including data were derived from different service areas, differences in building size and shape, and poorly defined or ambiguous building types.

The second data source of initial EUI values is that derived from other federal site analysis efforts where similar building types were considered. For this analysis adjustments were made to the regional EUI values where deemed appropriate based on experience at other similar sites. Tables B.25 and B.26 (in Appendix B) contain the fossil and electric EUI values that were used as the initial EUI values for Fort Irwin.

\subsection{Site-Specific Energy Use and Consumption}

A primary product of the energy baseline analysis for Fort Irwin is the site-specific EUI values for various building types and end uses that make up the energy consumption at Fort Irwin. These EUI values are considered reasonable representations of the magnitude of energy consumption among various end uses, buildings, and areas of Fort Irwin.

The initial step in the development of these values was to assess all available regional and published EUI data that might be applicable to Fort Irwin (Tables B.1-B.26). After reviewing various sources and matching existing data generated from PNL measurements at other facilities, a set of initial EUI values was derived (Tables B.25 and B.26). This set of values provides a reasonable starting EUI value to be used in assigning site-specific EUI values to Fort Irwin facilities.

The next step in EUI development involves the third primary EUI data source (metered data) as well as other site data such as occupancy, fuel availability, and other specific operational characteristics. In this step the initial EUI values are adjusted based on metered data and any available operational characteristics. For Fort Irwin a single adjustment factor was initially applied to initial EUI values that included the effects of building occupancy, fuel availability, and known building function. For example:

- Housing occupancy is known to be around $98 \%$.

- Only $31 \%$ of training buildings are known (based on real property data) to have propane fuel available.

- Only $77 \%$ of warehouses are known to have any cooling capacity (based on real property data).

These combined factors use available specific Fort Irwin characteristics to adjust the initial EUIs to more closely represent Fort Irwin energy use. In addition, any available actual metered or other billing data are also applied in place of the EUI system wherever appropriate. For example, the electric housing EUI values are derived from the actual Fort Irwin family housing total billing values.

The final step in deriving specific EUIs and allocating energy use among buildings is the reconciliation of the component energy use based on EUIs and other estimated consumption and the billing totals for Fort Irwin. This involves calculating energy use for each building type by multiplying the EUIs by the total square footage. These values are then added to any non-building energy use such as streetlights, water, and sewer. The total of all of these component energy uses should equal the total billed consumption for the Fort. At this point adjustments are made to the EUI values or other consumption values to come to a 
balance between the estimated and billed energy amounts. These final adjustments are made based on supplementary knowledge of facility characteristics. Tables 3.1 and 3.2 detail the final adjusted EUI values for the end uses and building types represented at Fort Irwin.

Table 3.1. Fort Irwin-Specific Propane Fuel Energy-Use Intensities $\left(\mathrm{kBtu} / \mathrm{ft}^{2} /\right.$ year $)$

\begin{tabular}{|c|c|c|c|c|c|}
\hline Bldg Type & Total & Heating & DHW & Cooking & Other \\
\hline ADMIN & 35.56 & 34.30 & 1.26 & 0.00 & 0.00 \\
\hline ADMIN-MT & 0.00 & 0.00 & 0.00 & 0.00 & 0.00 \\
\hline BRK/ADM & 36.37 & 28.97 & 7.40 & 0.00 & 0.00 \\
\hline CHAPEL & 28.03 & 26.14 & 1.33 & 0.56 & 0.00 \\
\hline CLINIC & 88.13 & 45.31 & 15.00 & 0.00 & 27.82 \\
\hline CLUB & 145.91 & 9.18 & 14.84 & 106.04 & 15.85 \\
\hline COMCATN & 30.86 & 30.32 & 0.53 & 0.00 & 0.00 \\
\hline DET-RR & 3.04 & 0.00 & 3.04 & 0.00 & 0.00 \\
\hline DGR & 10.84 & 10.40 & 0.44 & 0.00 & 0.00 \\
\hline DINING & 129.02 & 9.18 & 14.84 & 89.15 & 15.85 \\
\hline FUELDSP & 26.14 & 26.14 & 0.00 & 0.00 & 0.00 \\
\hline GROCERY & 21.20 & 8.25 & 3.77 & 2.85 & 6.34 \\
\hline HANGAR & 26.60 & 26.14 & 0.47 & 0.00 & 0.00 \\
\hline HOSPITL & 104.79 & 45.31 & 30.14 & 1.52 & 27.82 \\
\hline HOTEL & 0.00 & 0.00 & 0.00 & 0.00 & 0.00 \\
\hline HSG-FAM & 42.54 & 26.37 & 10.78 & 5.39 & 0.00 \\
\hline HUT & 0.00 & 0.00 & 0.00 & 0.00 & 0.00 \\
\hline LAB-MED & 68.82 & 26.00 & 15.00 & 0.00 & 27.82 \\
\hline MTRPOOL & 20.87 & 19.86 & 1.01 & 0.00 & 0.00 \\
\hline MWR & 24.17 & 23.00 & 1.17 & 0.00 & 0.00 \\
\hline OTHER & 27.46 & 26.14 & 1.33 & 0.00 & 0.00 \\
\hline PLT-BLDG & 56.06 & 8.26 & 1.20 & 0.00 & 46.60 \\
\hline POOL-OT & 50.91 & 0.00 & 5.35 & 0.00 & 45.56 \\
\hline PUMP & 0.00 & 0.00 & 0.00 & 0.00 & 0.00 \\
\hline REC & 34.32 & 25.35 & 8.97 & 0.00 & 0.00 \\
\hline RESTRNT & 72.96 & 4.59 & 7.42 & 53.02 & 7.92 \\
\hline SECURTY & 26.64 & 25.35 & 1.29 & 0.00 & 0.00 \\
\hline SHOP & 1.47 & 1.29 & 0.19 & 0.00 & 0.00 \\
\hline SHOP-AIR & 10.51 & 9.18 & 1.33 & 0.00 & 0.00 \\
\hline SHOP-ELC & 3.99 & 3.49 & 0.50 & 0.00 & 0.00 \\
\hline SHOP-HVY & 10.51 & 9.18 & 1.33 & 0.00 & 0.00 \\
\hline SHOP-WPN & 0.00 & 0.00 & 0.00 & 0.00 & 0.00 \\
\hline STOR-UH & 0.00 & 0.00 & 0.00 & 0.00 & 0.00 \\
\hline TRAING & 4.09 & 3.40 & 0.69 & 0.00 & 0.00 \\
\hline WHS & 6.24 & 5.69 & 0.54 & 0.00 & 0.00 \\
\hline WHS-CLD & 0.00 & 0.00 & 0.00 & 0.00 & 0.0 \\
\hline
\end{tabular}


Table 3.2. Fort Irwin-Specific Electric Energy-Use Intensities $\left(\mathrm{kWh} / \mathrm{ft}^{2} /\right.$ year)

\begin{tabular}{|c|c|c|c|c|c|c|c|c|c|c|c|c|}
\hline Bldg. Type & Area $\left(\mathrm{ft}^{2}\right)$ & Total & Heat & Cool & Vent & DHW & Cook & Int. Ltgs. & Ext. Ltgs. & Refrig. & Off. Eqp. & Other \\
\hline ADMIN & 362,029 & 11.11 & 0.00 & 2.00 & 0.98 & 0.00 & 0.05 & 5.00 & 1.00 & 0.12 & 1.46 & 0.50 \\
\hline ADMIN-MT & 275,376 & 12.05 & 0.96 & 3.86 & 0.36 & 0.09 & 0.04 & 4.82 & 0.41 & 0.10 & 1.20 & 0.21 \\
\hline BRK/ADM & 760,148 & 12.04 & 0.05 & 4.63 & 1.05 & 0.00 & 0.10 & 2.85 & 0.38 & 0.96 & 0.02 & 2.00 \\
\hline CHAPEL & 23,614 & 7.44 & 0.00 & 1.50 & 1.38 & 0.00 & 0.05 & 3.00 & 0.80 & 0.06 & 0.15 & 0.50 \\
\hline CLINIC & 25,310 & 27.96 & 0.00 & 4.72 & 1.86 & 0.00 & 0.10 & 9.59 & 1.00 & 0.57 & 3.28 & 6.85 \\
\hline CLUB & 67,429 & 35.72 & 0.00 & 5.97 & 6.32 & 0.00 & 4.60 & 3.00 & 1.00 & 10.54 & 0.04 & 4.26 \\
\hline COMCATN & 5,695 & 8.08 & 0.03 & 1.38 & 1.13 & 0.08 & 0.05 & 1.50 & 0.50 & 0.00 & 2.92 & 0.50 \\
\hline DET-RR & 17,644 & 4.91 & 0.00 & 0.00 & 1.73 & 0.78 & 0.00 & 2.00 & 0.40 & 0.00 & 0.00 & 0.00 \\
\hline DGR & 114,662 & 10.20 & 0.01 & 0.75 & 1.22 & 0.00 & 0.05 & 5.62 & 1.00 & 0.41 & 0.18 & 0.95 \\
\hline DINING & 35,939 & 41.62 & 0.10 & 5.97 & 6.32 & 0.00 & 4.60 & 7.14 & 2.67 & 10.54 & 0.04 & 4.26 \\
\hline FUELDSP & 64,715 & 1.18 & 0.00 & 0.02 & 0.02 & 0.00 & 0.00 & 0.75 & 0.40 & 0.00 & 0.00 & 0.00 \\
\hline GROCERY & 56,500 & 41.09 & 0.00 & 3.00 & 2.01 & 0.00 & 0.77 & 10.69 & 1.52 & 20.90 & 0.42 & 1.78 \\
\hline HANGAR & 82,520 & 3.30 & 0.00 & 0.00 & 0.00 & 0.00 & 0.10 & 1.50 & 0.80 & 0.10 & 0.30 & 0.50 \\
\hline HOSPITL & 63,818 & 37.34 & 0.00 & $9: 44$ & 6.32 & 0.00 & 0.30 & 9.59 & 1.00 & 0.57 & 3.28 & 6.85 \\
\hline HOTEL & 11,566 & 14.88 & 4.04 & 2.44 & 0.88 & 2.50 & 0.05 & 3.80 & 0.40 & 0.25 & 0.02 & 0.50 \\
\hline HSG-FAM & $2,961,830$ & 6.91 & 0.00 & 2.91 & 0.80 & 0.00 & 0.10 & 1.00 & 0.10 & 1.40 & 0.00 & 0.60 \\
\hline HUT & 152,478 & 0.00 & 0.00 & 0.00 & 0.00 & 0.00 & 0.00 & 0.00 & 0.00 & 0.00 & 0.00 & 0.00 \\
\hline LAB-MED & 9,415 & 32.40 & 0.00 & 9.44 & 2.33 & 0.00 & 0.10 & 9.59 & 0.25 & 0.57 & 3.28 & 6.85 \\
\hline MTRPOOL & 309,890 & 7.77 & 0.00 & 1.28 & 1.47 & 0.00 & 0.10 & 3.00 & 0.80 & 0.10 & 0.10 & 0.93 \\
\hline MWR & 125,854 & 11.66 & 0.00 & 1.86 & 1.60 & 0.08 & 0.05 & 6.00 & 0.80 & 0.05 & 0.30 & 0.93 \\
\hline OTHER & 1,536 & 6.86 & 0.00 & 0.75 & 1.38 & 0.00 & 0.00 & 3.00 & 0.80 & 0.00 & 0.00 & 0.93 \\
\hline PLT-BLDG & 12,366 & 3.25 & 0.01 & 0.18 & 0.21 & 0.00 & 0.05 & 2.00 & 0.80 & 0.00 & 0.00 & 0.00 \\
\hline POOL-OT & 7,727 & 1.42 & 0.00 & 0.00 & 0.52 & 0.00 & 0.00 & 0.50 & 0.40 & 0.00 & 0.00 & 0.00 \\
\hline PUMP & 10,976 & 0.65 & 0.00 & 0.00 & 0.00 & 0.00 & 0.25 & 0.40 & 0.00 & 0.00 & 0.00 & 0.00 \\
\hline REC & 62,016 & 15.29 & 0.00 & 1.50 & 1.86 & 0.00 & 0.05 & 10.00 & 0.80 & 0.05 & 0.10 & 0.93 \\
\hline RESTRNT & 4,712 & 44.55 & 0.00 & 9.00 & 6.32 & 0.00 & 4.60 & 7.14 & 2.67 & 10.54 & 0.04 & 4.26 \\
\hline SECURTY & 17,498 & 13.45 & 0.00 & 0.75 & 1.21 & 0.00 & 0.10 & 6.00 & 1.43 & 0.24 & 1.00 & 2.72 \\
\hline SHOP & 189,273 & 6.55 & 0.00 & 0.75 & 1.38 & 0.39 & 0.10 & 2.00 & 0.80 & 0.10 & 0.10 & 0.93 \\
\hline SHOP-AIR & 2,000 & 6.16 & 0.00 & 0.75 & 1.38 & 0.00 & 0.10 & 2.00 & 0.80 & 0.10 & 0.10 & 0.93 \\
\hline SHOP-ELC & 22,684 & 6.58 & 0.03 & 0.99 & 1.14 & 0.39 & 0.10 & 2.00 & 0.80 & 0.10 & 0.10 & 0.93 \\
\hline SHOP-HVY & 3,200 & 5.41 & 0.00 & 0.00 & 1.38 & 0.00 & 0.10 & 2.00 & 0.80 & 0.10 & 0.10 & 0.93 \\
\hline SHOP-WPN & 8,022 & 7.04 & 0.10 & 0.75 & 1.38 & 0.78 & 0.10 & 2.00 & 0.80 & 0.10 & 0.10 & 0.93 \\
\hline STOR-UH & 157,442 & 0.12 & 0.00 & 0.00 & 0.00 & 0.00 & 0.00 & 0.10 & 0.02 & 0.00 & 0.00 & 0.00 \\
\hline TRAING & 72,959 & 7.22 & 0.06 & 2.79 & 0.77 & 0.00 & 0.00 & 2.85 & 0.70 & 0.00 & 0.05 & 0.00 \\
\hline WHS & 288,093 & 2.95 & 0.01 & 0.73 & 0.53 & 0.00 & 0.00 & 1.00 & 0.09 & 0.05 & 0.05 & 0.50 \\
\hline WHS-CLD & 14,500 & 48.85 & 0.10 & 0.47 & 0.55 & 0.00 & 0.00 & 2.00 & 0.19 & 45.00 & 0.05 & 0.50 \\
\hline
\end{tabular}




\subsection{Electrical Consumption}

\subsection{Metering and Data Summary}

The three sources of metered electricity consumption data at Fort Irwin are utility meter readings, onbase metering, and PNL substation metering.

Utility meter readings for June 1992 through May 1993 are detailed in Table 4.1. These represent the utility billing records used as the sample year baseline consumption. To provide appropriate billing data to various Army and private organizations, the total Fort Irwin bill is apportioned using on-base metering and engineering judgment into bills for family and General's housing, trailer court spaces, and other reimbursable facilities. Many of the on-base meter records were unusable due to meter errors or missing data. The billing values prepared by Fort Irwin for the family and General's housing, trailer court area, and school were directly usable in determining appropriate EUI values. Metering of the five feeders at the "old" substation was completed by PNL during 1990. The resulting data covered two-week periods in three summer months. These data were useful as a general check of other consumption levels but not as a primary data point for EUI development. See Section 4.3 for analysis of the PNL-collected demand level data.

Table 4.1. Fort Irwin Electric Demand and Consumption - 5/92 to 4/93

\begin{tabular}{||l|c|c|c|c||}
\hline \multicolumn{1}{|c|}{ Month } & Total kWh Consumed & Peak Demand (kW) & Cost & Fiscal Year \\
\hline JUN & $7,258,800$ & 38,645 & $\$ 651,872$ & 1992 \\
\hline JUL & $7,362,000$ & 45,735 & $\$ 763,039$ & \\
\hline AUG & $8,436,000$ & 47,558 & $\$ 821,562$ & \\
\hline SEP & $7,872,000$ & 43,257 & $\$ 784,696$ & \\
\hline OCT & $6,632,400$ & 42,048 & $\$ 559,348$ & \\
\hline NOV & $4,926,000$ & 24,480 & $\$ 388,815$ & \\
\hline DEC & $5,020,800$ & 24,613 & $\$ 432,916$ & \\
\hline JAN & $5,221,200$ & 26,893 & $\$ 352,226$ & 1993 \\
\hline FEB & $4,760,400$ & 23,347 & $\$ 358,907$ & \\
\hline MAR & $4,465,200$ & 23,501 & $\$ 358,542$ & \\
\hline APR & $5,076,000$ & 26,035 & $\$ 377,793$ & \\
\hline MAY & $5,839,200$ & 33,139 & $\$ 421,796$ & \\
\hline TOTALS & $72,870,000$ & & $\$ 6,271,513$ & \\
\hline
\end{tabular}




\subsection{Energy-Use Breakdown}

The electrical consumption for buildings at Fort Irwin is shown in Table 4.2. Consumption is apportioned by building type and by primary end use in each building type. Table 4.3 shows the total electrical usage for buildings (from Table 4.2) along with an accounting of all electrical usage not directly associated with buildings such as transmission and distribution losses, water supply and sewage treatment. The electrical consumption shown in Table 4.3 accounts for nearly $100 \%$ of the total use for the sample base year at Fort Irwin.

Table 4.2. Sample Fort Irwin Buildings Electrical Usage (kWh/year)

\begin{tabular}{|c|c|c|c|c|c|c|c|c|c|c|c|c|}
\hline Bldg. Type & Area (t) & Total & Heat & Cool & Vent & DHW & Cook & Int. Lige. & Ext. Ltgs. & Refrig. & Off. Eqp. & Otber \\
\hline ADMIN & 362,029 & $4,021,672$ & 0 & 724,058 & 354,499 & 0 & 18,101 & $1,810,145$ & 362,029 & 44,168 & 527,657 & 181,015 \\
\hline ADMIN-MT & 275,376 & $3,318,832$ & 205,462 & $1,062,951$ & 99,135 & 23,682 & 11,290 & $1,327,312$ & 113,455 & 27.262 & 331,553 & 56,727 \\
\hline BRK/ADM & 760,148 & $9,151,680$ & 37,430 & $3,522,002$ & 797,243 & 0 & 76,015 & $2,166,422$ & 287,051 & 727,842 & 16,248 & $1,520,828$ \\
\hline CHAPEL & 23,614 & 175,688 & 0 & 35,421 & 32,587 & 0 & 1,181 & 70,842 & 18,950 & 1,417 & 3,483 & 11,807 \\
\hline CLINIC & 25,310 & 707,722 & 0 & 119,495 & 47,137 & 0 & 2,531 & 242,660 & 25,310 & 14,325 & 83,017 & 173,247 \\
\hline CLUB & 67,429 & $2,408,564$ & 0 & 402,551 & 425,983 & 0 & 309,836 & 202,287 & 67,429 & 710,702 & 2,866 & 286,910 \\
\hline COMCATN & 5,695 & 46,008 & 146 & 7.859 & 6,413 & 467 & 285 & 8,543 & 2,848 & 0 & 16.601 & 2,848 \\
\hline DET-RR & 17,644 & 86,566 & 0 & 0 & 30,436 & 13,762 & 0 & 35,238 & 7,080 & 0 & 0 & 0 \\
\hline DGR & 114,662 & $1,169,828$ & 1,364 & 85,997 & 140,346 & 0 & 5,733 & 644,400 & 114,662 & 47,470 & 20,926 & 108,929 \\
\hline DNING & 35,939 & $1,495,890$ & 3,603 & 214,556 & 227,045 & 0 & 165,140 & 256,515 & $95, m$ & 378,797 & 1,527 & 152,920 \\
\hline FUELDSP & 64,715 & 76,590 & 0 & 971 & 1,116 & 0 & 0 & 48,536 & 25,967 & 0 & 0 & 0 \\
\hline GROCERY & 56,500 & $2,321,416$ & 0 & 169,500 & 113,565 & 0 & 43,364 & 603,985 & 85,598 & $1,181,076$ & 23,871 & 100,457 \\
\hline HANGAR & 82,520 & 272,110 & 0 & 0 & 0 & 0 & 8,252 & 123,780 & 66,222 & 8,252 & 24,343 & 41,260 \\
\hline HOSPITL & 63,818 & $2,382,868$ & 0 & 602,601 & 403,330 & 0 & 18,986 & 611,855 & 63,818 & 36,121 & 209,323 & 436,834 \\
\hline HOTEL & 11,566 & 172,101 & 46,700 & 28,209 & 10,215 & 28,944 & 578 & 43,922 & 4,597 & 2,892 & 260 & 5,783 \\
\hline HSG-FAM & $2,961,830$ & $20,459,433$ & 0 & $8,612,113$ & $2,369,464$ & 0 & 296.183 & $2,961,830$ & 296.183 & $4,146,562$ & 0 & $1,777.098$ \\
\hline HUT & 152,478 & 0 & 0 & 0 & 0 & 0 & 0 & 0 & 0 & 0 & 0 & 0 \\
\hline LAB-MED & 9,415 & 305,060 & 0 & 88,901 & 21,918 & 0 & 942 & 90,266 & 2,377 & 5,329 & 30,881 & 64,446 \\
\hline MTRPOOL & 309,890 & $2,407,458$ & 0 & 395,110 & 454,376 & 0 & 30,989 & 929,670 & 248,687 & 30,989 & 30,989 & 286,648 \\
\hline MWR & 125,854 & $1.468,055$ & 0 & 234,088 & 201,901 & 9,817 & 6.293 & 755,124 & 100,998 & 6,293 & 37,127 & 116,415 \\
\hline OTHER & 1.536 & 10,533 & 0 & 1.152 & 2,120 & 0 & 0 & 4,608 & 1,233 & 0 & 0 & 1.421 \\
\hline PLT-BLDG & 12,366 & 40,208 & 148 & 2,226 & 2,560 & 0 & 618 & 24,732 & 9,924 & 0 & 0 & 0 \\
\hline POOL-OT & 7,727 & 10.963 & 0 & 0 & 3,999 & 0 & 0 & 3,864 & 3.100 & 0 & 0 & 0 \\
\hline PUMP & 10,976 & 7,148 & 0 & 0 & 0 & 0 & 0 & 2,744 & 4,404 & 0 & 0 & 0 \\
\hline REC & 62,016 & 948,318 & 0 & 93,024 & 115,598 & 0 & 3,101 & 620,160 & 49,768 & 3,101 & 6.202 & 57,365 \\
\hline RESTRNT & 4,712 & 209,931 & 0 & 42,408 & 29,768 & 0 & 21,652 & 33,632 & 12,557 & 49,664 & 200 & 20,050 \\
\hline SECURTY & 17,498 & 235,396 & 17 & 13,124 & 21,203 & 0 & 1,730 & 104,988 & 25,022 & 4,270 & 17,498 & 47,525 \\
\hline SHOP & 189,273 & $1,239,833$ & 568 & 141,955 & 261,197 & 73,816 & 18,927 & 378,546 & 151,892 & 18,927 & 18,927 & 175,078 \\
\hline SHOP-AR & 2,000 & 12,320 & 0 & 1,500 & 2,760 & 0 & 200 & 4,000 & 1,600 & 200 & 200 & 1,860 \\
\hline SHOP-ELC & 22,684 & 149.170 & 681 & 22,457 & 25,826 & 8,847 & 2,268 & 45,368 & 18,204 & 2,268 & 2,268 & 20,983 \\
\hline SHOP-HVY & 3,200 & 17,312 & 0 & 0 & 4,416 & 0 & 320 & 6,400 & 2,560 & 320 & 320 & 2,976 \\
\hline SHOP-WPN & 8,022 & 56,455 & 802 & 6,017 & 11,070 & 6,257 & 802 & 16,044 & 6,438 & 802 & 802 & 7,420 \\
\hline STOR-UH & 157,442 & 18,657 & 0 & 0 & 0 & 0 & 0 & 15,744 & 2,913 & 0 & 0 & 0 \\
\hline TRAING & 72,959 & 526,819 & 4,523 & 203,556 & 56,453 & 0 & 0 & 207,568 & 51,071 & 0 & 3,648 & 0 \\
\hline WHS & 288,093 & 850,180 & 1,440 & 209,409 & 151,733 & 0 & 0 & 288,093 & 26,649 & 14,405 & 14,405 & 144.047 \\
\hline WHS-CLD & 14,500 & 708,386 & 1,450 & 6,844 & 7,934 & 0 & 0 & 29,000 & 2,683 & 652,500 & 725 & 7,250 \\
\hline Tocals & $6,401,436$ & $57,489,159$ & 364,336 & $17,050,654$ & $6,433,347$ & 165,593 & $1,045,337$ & $14,718,873$ & $2,359,054$ & $8,115,953$ & $1,425,868$ & $5,810,145$ \\
\hline$\$$ of Total & - & $100.0 \%$ & $0.6 \%$ & $29.7 \%$ & $11.2 \%$ & $0.3 \%$ & $1.8 \%$ & $25.6 \%$ & $4.1 \%$ & $14.1 \%$ & $2.5 \%$ & $10.1 \%$ \\
\hline
\end{tabular}


Table 4.3. Overall Fort Irwin Electric Consumption (MWh/year)

\begin{tabular}{||l|c|c||}
\hline \multicolumn{1}{|c|}{ Sector } & $\begin{array}{c}\text { Consumption } \\
\text { (MWh/year) }\end{array}$ & $\begin{array}{c}\text { Percent of } \\
\text { Consumption }\end{array}$ \\
\hline Buildings & 58,106 & $81.1 \%$ \\
\hline $\begin{array}{l}\text { Water Supply/Sewage } \\
\text { Treatment }\end{array}$ & 7,876 & $11.0 \%$ \\
\hline Transformer Losses & 2,392 & $3.3 \%$ \\
\hline Street/Lot Lighting & 1,764 & $2.5 \%$ \\
\hline Fort Irwin School & 1,100 & $1.5 \%$ \\
\hline Trailer Sites & 422 & $0.6 \%$ \\
\hline General's Quarters & 21 & $<0.1 \%$ \\
\hline Total & 71,681 & $100.0 \%$ \\
\hline
\end{tabular}

\subsection{Electrical Demand Summary}

Time-of-use data were collected through PNL metering equipment as part of a separate study sponsored by FORSCOM. The metering was completed for all five main feeders and produced good usable data for two-week periods in April, June and August of 1990. The study results indicate that the overall Fort Irwin demand profile is generally flat - indicating little easy opportunity for any peak shaving options that do not involve general load reduction. Figure 4.1 presents the average weekday load profiles for the available metered data in April, June and August. Figure 4.2 presents the corresponding profiles for weekends. Figures 4.3 through 4.8 present the demand profiles for each month, by feeder.

Additional detail on Fort Irwin feeder demand can be found in the Mobile Energy Laboratory (MEL) report for the Federal Energy Management Program (FEMP) titled Test Report for Fort Irwin: Electric Substation Monitoring (unpublished). 


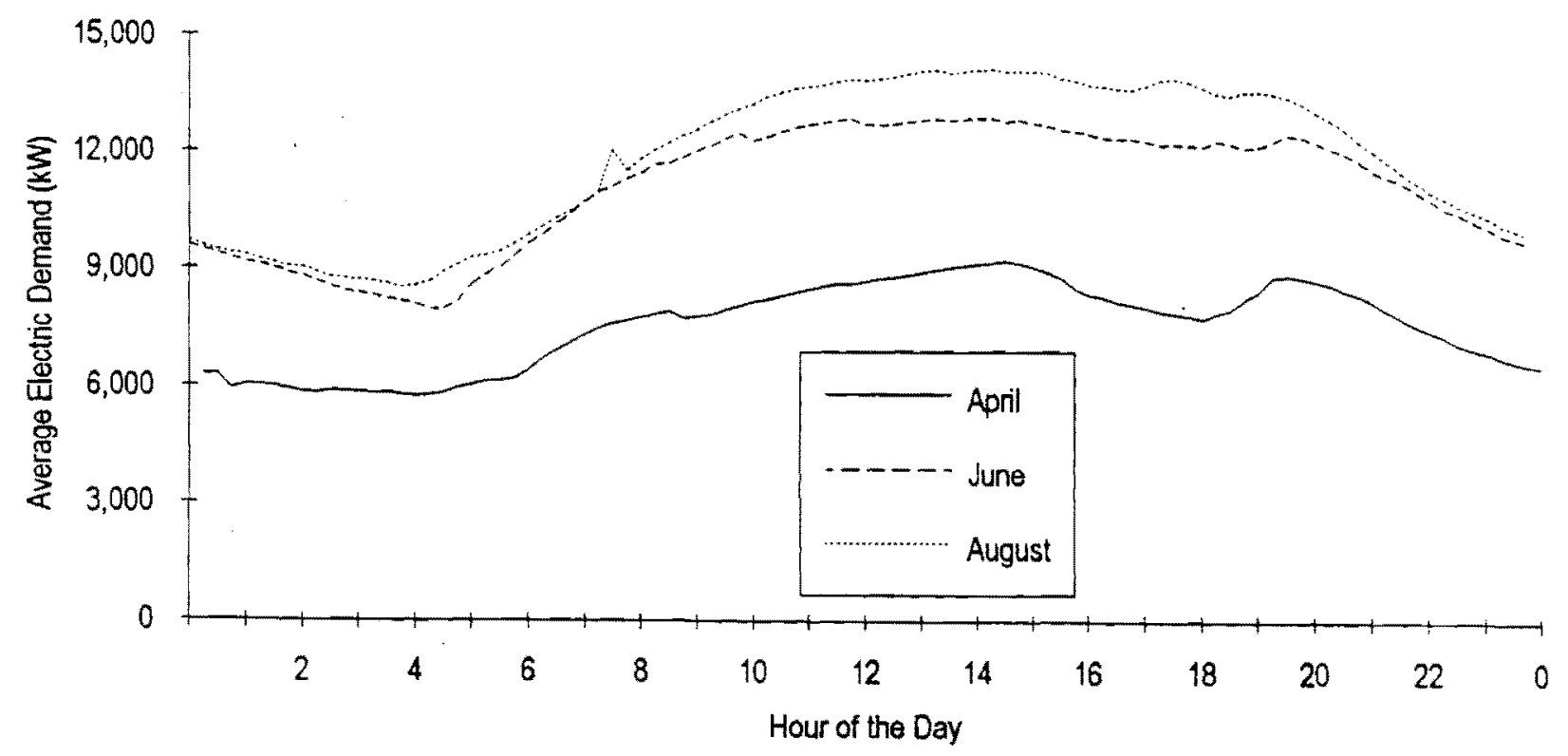

Figure 4.1. Weekday Average Electric Load Profiles

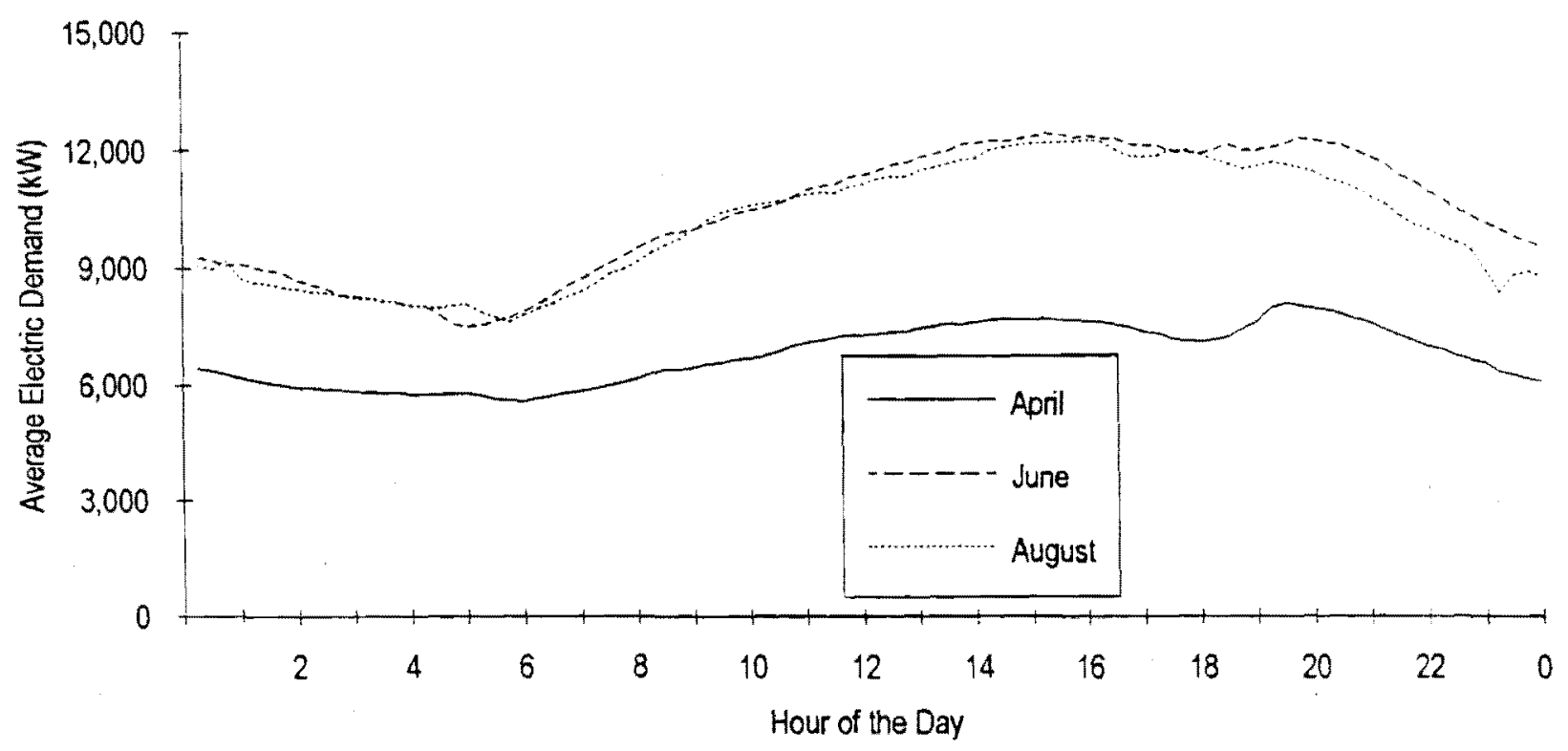

Figure 4.2. Weekend Average Electric Load Profiles 


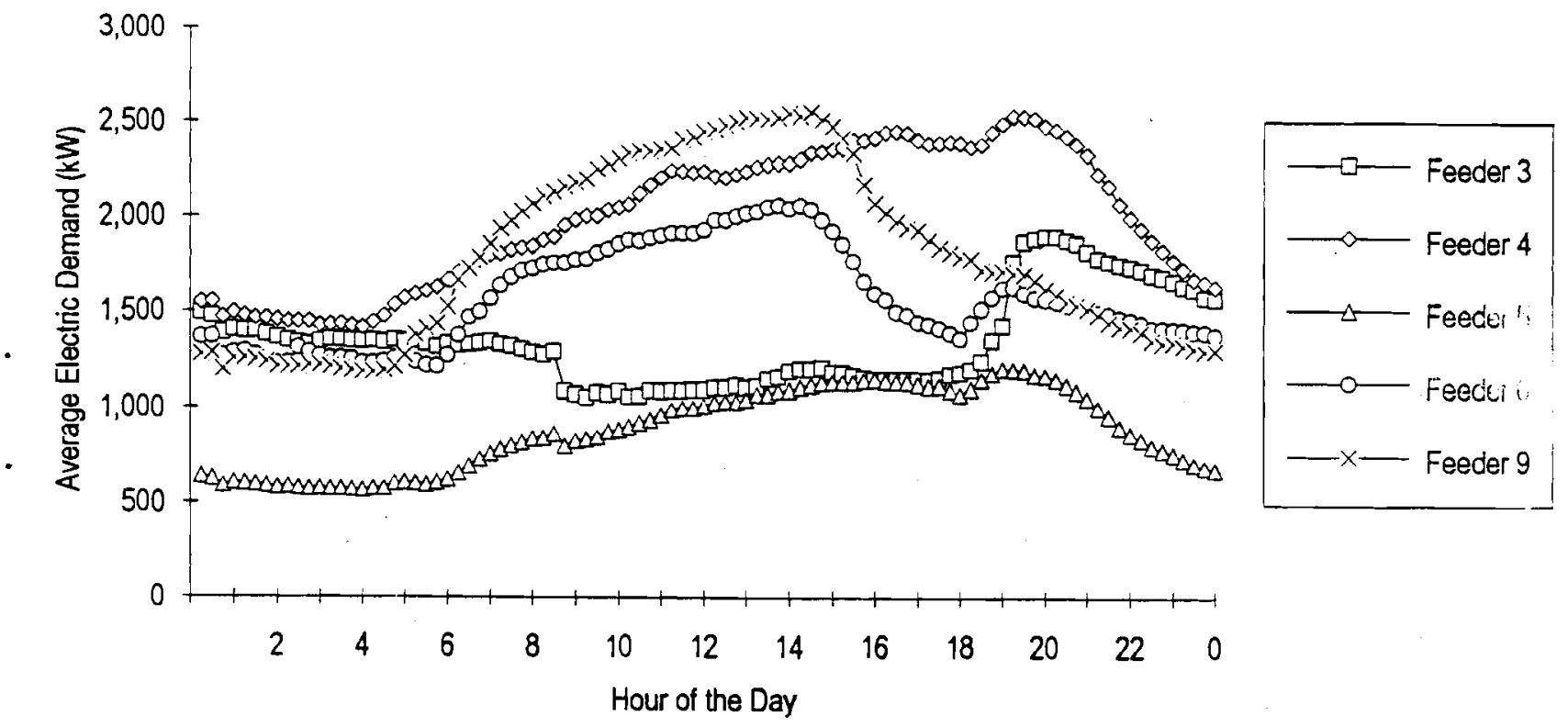

Figure 4.3. April Weekday Average Electric Demand by Feeder

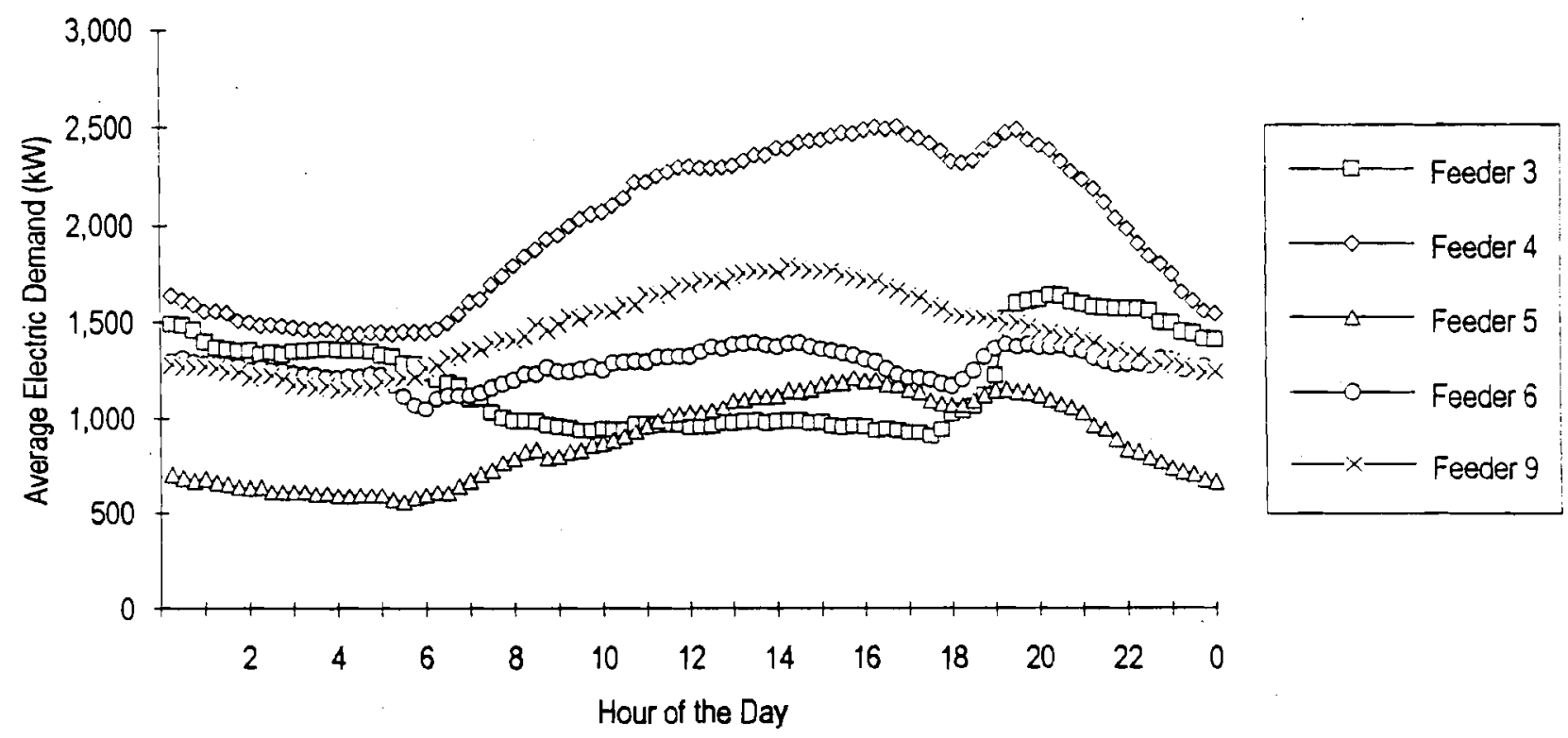

Figure 4.4. April Weekend Average Electric Demand by Feeder 


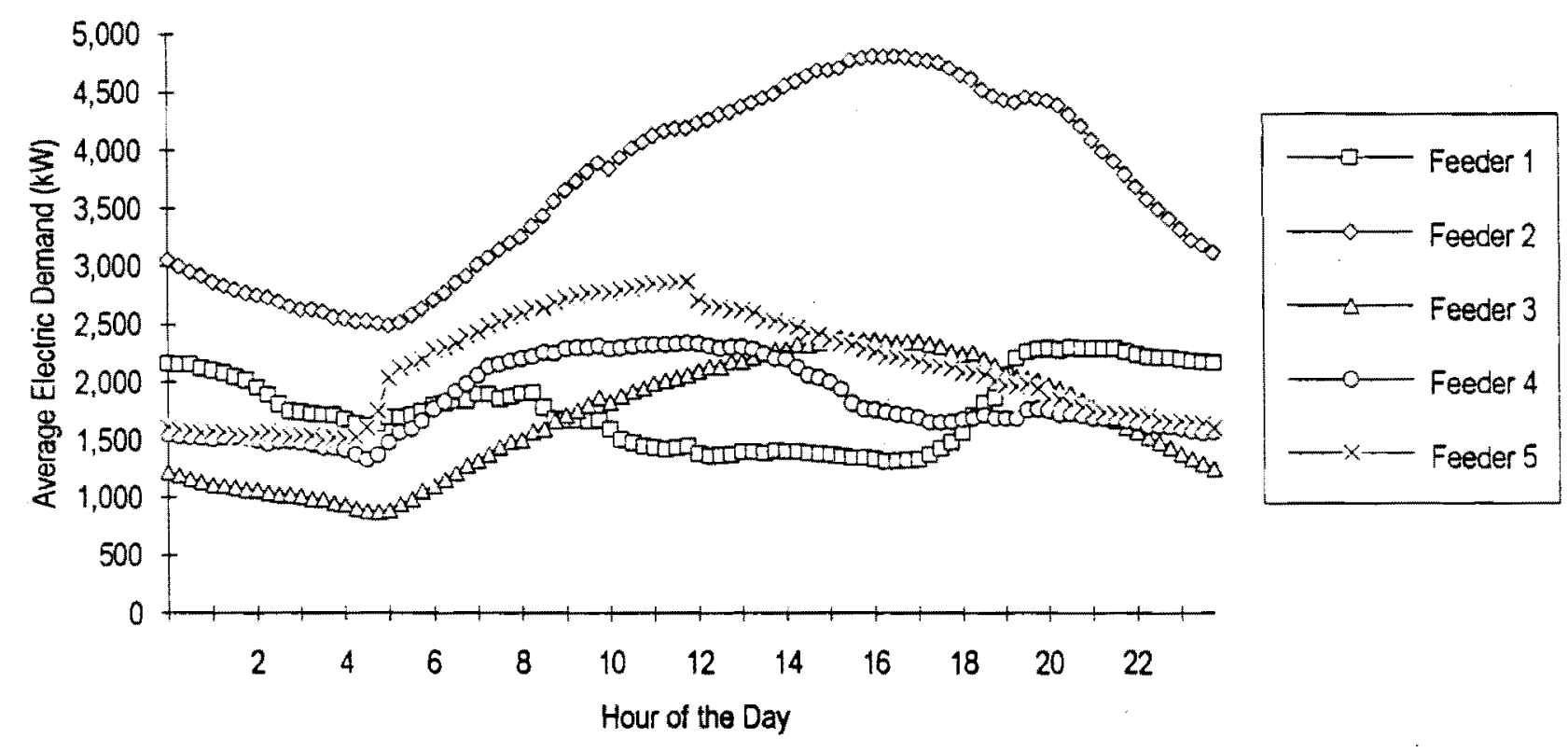

Figure 4.5. June Weekday Average Electric Demand by Feeder

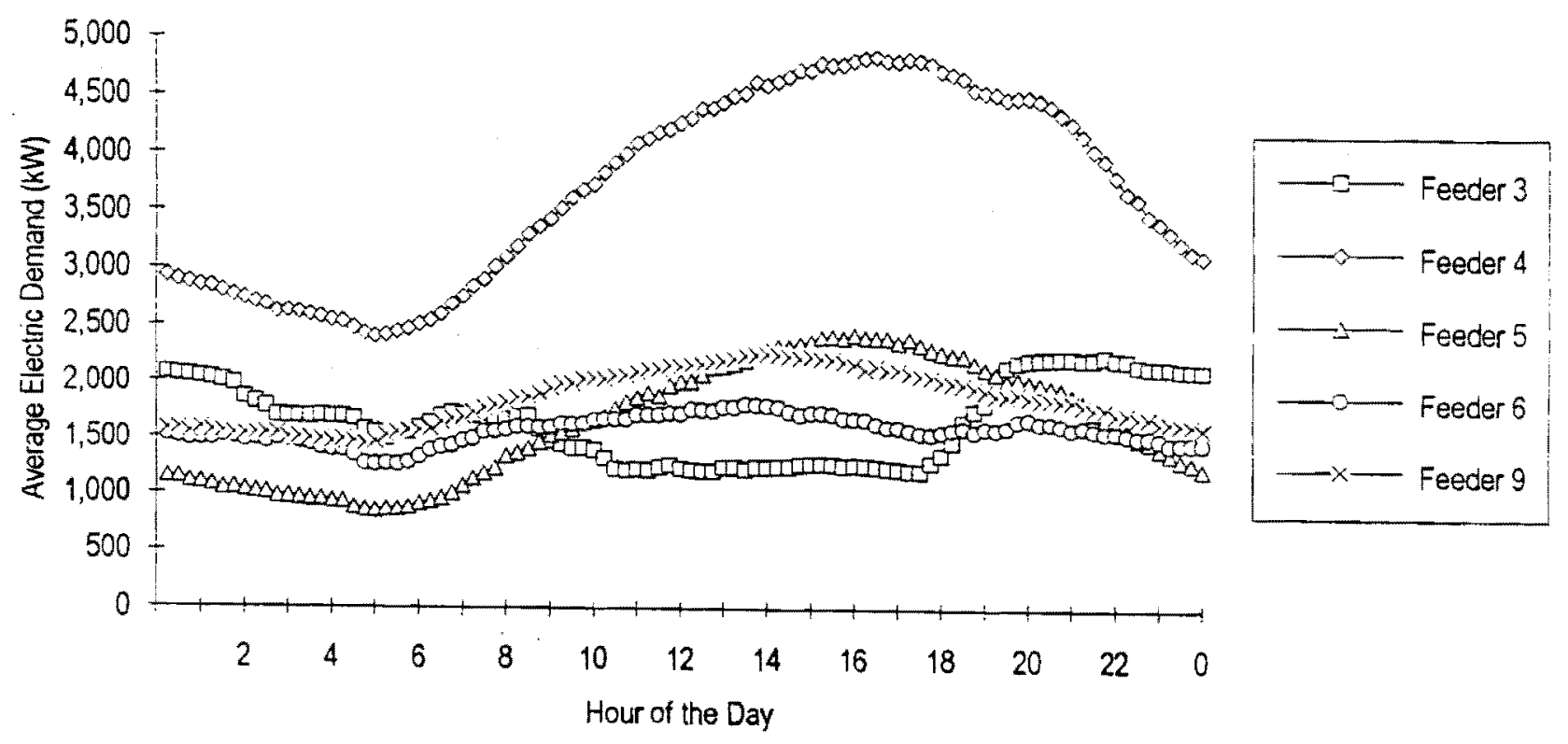

Figure 4.6. June Weekend Average Electric Demand by Feeder 


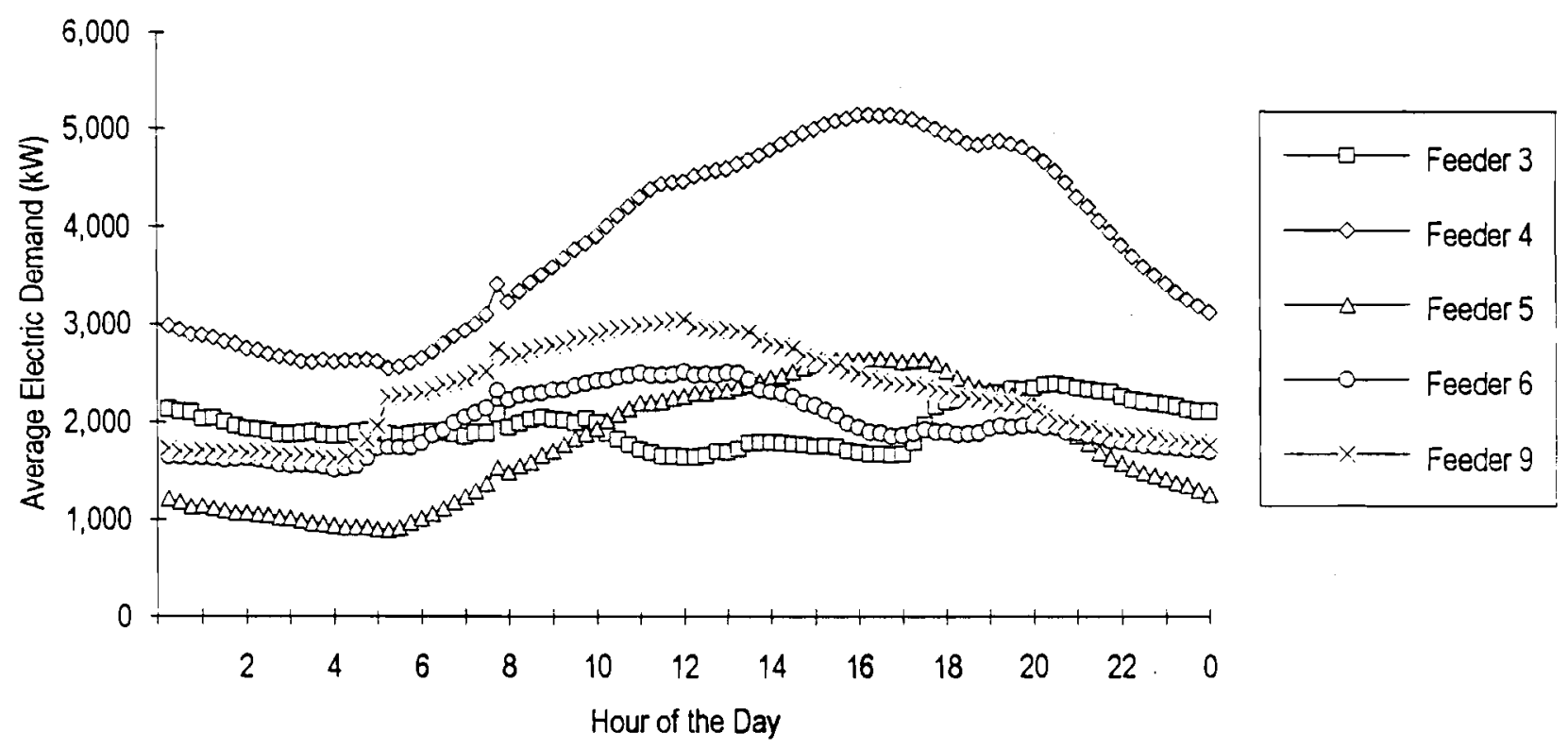

Figure 4.7. August Weekday Average Electric Demand by Feeder

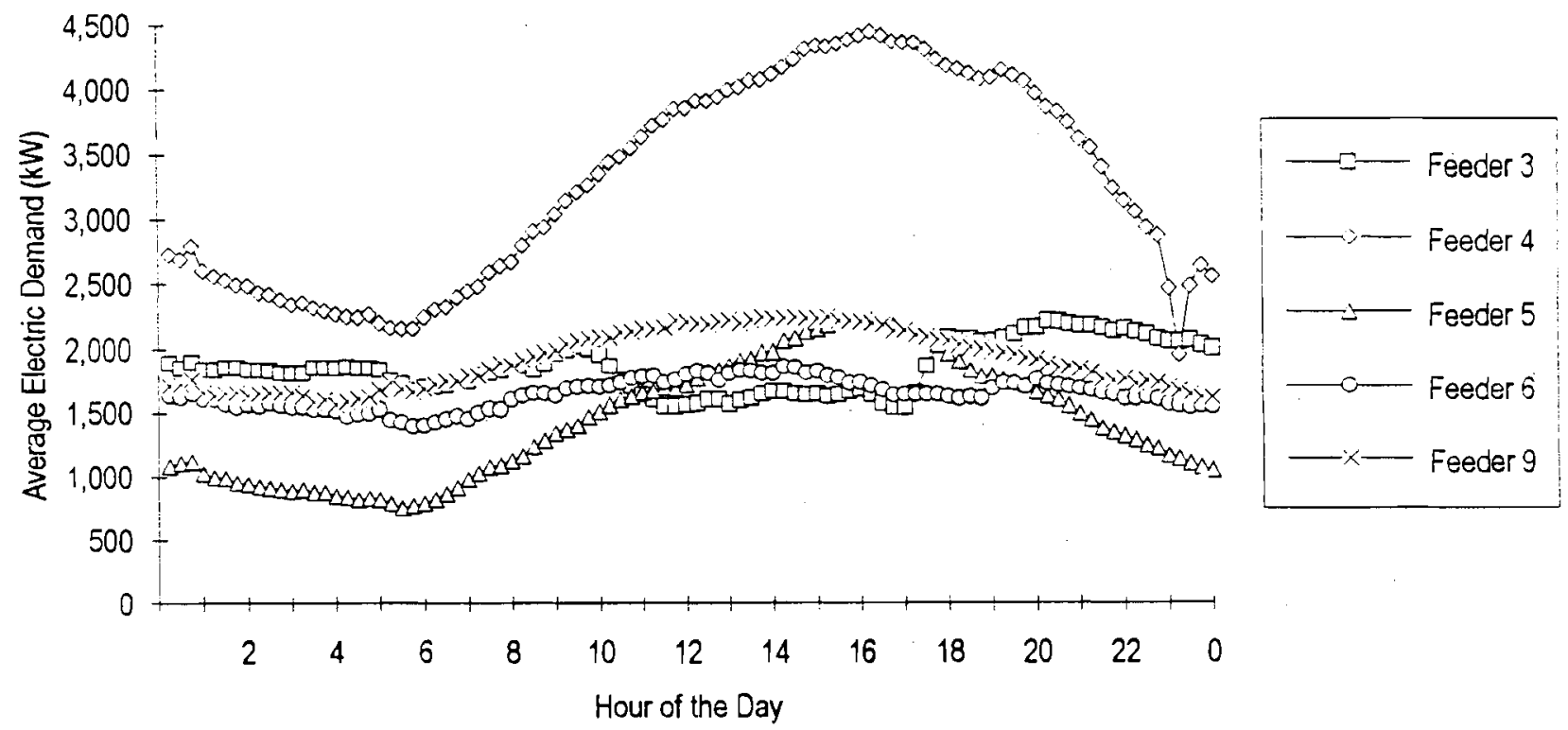

Figure 4.8. August Weekend Average Electric Demand by Feeder 


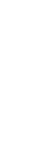

. 


\subsection{Propane Consumption}

\subsection{Metering and Data Summary}

Propane delivery data were provided by Fort Irwin as monthly delivery totals to the distribution storage tanks. Some on-base metering exists for gas distribution. Unfortunately, most was unusable due to inoperable meters, questionable, or missing data. Metered values for the General's housing, dining and commissary facilities were used in the calculation of EUI values. The consumption for March 1991 through February 1992 was chosen as a sample yearly use.

\subsection{Energy-Use Breakdown}

Propane consumption for Fort Irwin buildings is shown in Table 5.1. The consumption is apportioned within each building type, for each of its primary end uses. All of the propane use at Fort Irwin is accounted for in Table 5.2. The consumption of propane by the four central systems is represented by the consumption of each of the buildings (in Table 5.1) that are on the systems. A relatively small amount of loss due to plant inefficiencies is expected but not considered critical to this baseline assessment. 
Table 5.1. Sample Fort Irwin Propane Consumption (MBtu/year)

\begin{tabular}{|c|c|c|c|c|c|c|}
\hline Bldg. Type & Area $\left(\mathrm{ft}^{2}\right)$ & Total & Heating & DHW & Cooking & Other \\
\hline ADMIN & 362,029 & 12,872 & 12,416 & 457 & 0 & 0 \\
\hline ADMIN-MT & 275,376 & 0 & 0 & 0 & 0 & 0 \\
\hline BRK/ADM & 760,148 & 27,644 & 22,021 & 5,622 & 0 & 0 \\
\hline CHAPEL & 23,614 & 662 & 617 & 31 & 13 & 0 \\
\hline CLINIC & 25,310 & 2,231 & 1,147 & 380 & 0 & 704 \\
\hline CLUB & 67,429 & 9,839 & 619 & 1,001 & 7,150 & 1,069 \\
\hline COMCATN & 5,695 & 176 & 173 & 3 & 0 & 0 \\
\hline DET-RR & 17,644 & 54 & 0 & 54 & 0 & 0 \\
\hline DGR & 114,662 & 1,243 & 1,193 & 51 & 0 & 0 \\
\hline DINING & 35,939 & 5,244 & 330 & 533 & 3,811 & 570 \\
\hline FUELDSP & 64,715 & 1,691 & 1,691 & 0 & 0 & 0 \\
\hline GROCERY & 56,500 & 1,198 & 466 & 213 & 161 & 358 \\
\hline HANGAR & 82,520 & 2,195 & 2,157 & 38 & 0 & 0 \\
\hline HOSPITL & 63,818 & 6,687 & 2,892 & 1,923 & 97 & 1,776 \\
\hline HOTEL & 11,566 & 0 & 0 & 0 & 0 & 0 \\
\hline HSG-FAM & $2,961,830$ & 126,002 & 78,109 & 31,929 & 15,964 & 0 \\
\hline HUT & 152,478 & 0 & 0 & 0 & 0 & 0 \\
\hline LAB-MED & 9,415 & 648 & 245 & 141 & 0 & 262 \\
\hline MTRPOOL & 309,890 & 6,468 & 6,155 & 313 & 0 & 0 \\
\hline MWR & 125,854 & 3,042 & 2,894 & 147 & 0 & 0 \\
\hline OTHER & 1,536 & 42 & 40 & 2 & 0 & 0 \\
\hline PLT-BLDG & 12,366 & 693 & 102 & 15 & 0 & 576 \\
\hline POOL-OT & 7,727 & 393 & 0 & 41 & 0 & 352 \\
\hline PUMP & 10,976 & 0 & 0 & 0 & 0 & 0 \\
\hline REC & 62,016 & 2,128 & 1,572 & 556 & 0 & 0 \\
\hline RESTRNT & 4,712 & 344 & 22 & 35 & 250 & 37 \\
\hline SECURTY & 17,498 & 466 & 444 & 23 & 0 & 0 \\
\hline SHOP & 189,273 & 279 & 243 & 35 & 0 & 0 \\
\hline SHOP-AIR & 2,000 & 21 & 18 & 3 & 0 & 0 \\
\hline SHOP-ELC & 22,684 & 91 & 79 & 11 & 0 & 0 \\
\hline SHOP-HVY & 3,200 & 34 & 29 & 4 & 0 & 0 \\
\hline SHOP-WPN & 8,022 & 0 & 0 & 0 & 0 & 0 \\
\hline STOR-UH & 157,442 & 0 & 0 & 0 & 0 & 0 \\
\hline TRAING & 72,959 & 299 & 248 & 50 & 0 & 0 \\
\hline WHS & 288,093 & 1,797 & 1,640 & 156 & 0 & 0 \\
\hline WHS-CLD & 14,500 & 0 & 0 & 0 & 0 & 0 \\
\hline TOTAL & $6,401,436$ & 213,874 & 137,563 & 43,767 & 26,840 & 5,703 \\
\hline$\%$ OF TOTAL & - & 100.0 & 64.3 & 20.5 & 12.5 & 2.7 \\
\hline
\end{tabular}


Table 5.2. Overall Fort Irwin Propane Consumption (MBtu/year)

\begin{tabular}{||l|r|c||}
\hline \multicolumn{1}{|c|}{ Sector } & $\begin{array}{c}\text { Consumption } \\
\text { (MBtu/year) }\end{array}$ & $\begin{array}{c}\text { Percent of } \\
\text { Consumption }\end{array}$ \\
\hline Buildings & 213,874 & $94.7 \%$ \\
\hline Fort Irwin School & 11,582 & $5.1 \%$ \\
\hline Trailer Sites & 217 & $<0.1 \%$ \\
\hline General's Quarters & 107 & $<0.1 \%$ \\
\hline Total & 225,780 & $100.0 \%$ \\
\hline
\end{tabular}


,

. 


\subsection{Transportation Fuel Consumption}

\subsection{Metering and Data Summary}

Transportation fuel quantities were provided by Fort Irwin as yearly total values for gasoline, diesel, JP-4, and JP-8 fuels. JP-4 is used almost exclusively by helicopters. JP-8 is used by both helicopters and as a replacement fuel for diesel. According to site personnel, there is an effort underway to completely eliminate the use of diesel fuel, replacing it with JP-8. Portions of each of the fuels are used for field operations by the rotational units that train at Fort Irwin. Basic vehicle records were available for Fort Irwin and on-site General Services Administration (GSA) ground vehicles. Table 6.1 shows type, fuel, and quantities of ground vehicles. No information was collected for tactical vehicles or aircraft that would consume the JP-4 and/or JP-8 fuels.

Table 6.1. Current On-Site Fort Irwin Vehicle Inventory

\begin{tabular}{||l|l|r||}
\hline \multicolumn{1}{|c|}{ Vehicle Type } & Fuel Type & \multicolumn{1}{c|}{ Quantity } \\
\hline Sedan & Gasoline & 72 \\
\hline Ambulance & Gasoline & 3 \\
\hline Truck & Gasoline & 116 \\
\hline Truck & Diesel & 12 \\
\hline Truck w/Trailer & Diesel & 5 \\
\hline Pickup Truck & Gasoline & 82 \\
\hline Passenger Van & Gasoline & 91 \\
\hline Passenger Van & Diesel & 3 \\
\hline Bus & Diesel & 12 \\
\hline Forklift & Diesel & 16 \\
\hline Misc. (backhoe, grader, etc.) & Diesel & 11 \\
\hline Total & & 423 \\
\hline
\end{tabular}

\subsection{Energy-Use Breakdown}

Table 6.2 provides details on sample yearly consumption as well as estimates of field use quantities provided by Fort Irwin. 
Table 6.2. Sample Fort Irwin Vehicle Fuel Consumption (MBtu/year)

\begin{tabular}{||l|c|c||}
\hline \multicolumn{1}{|c|}{ Fuel Type } & $\begin{array}{c}\text { Yearly } \\
\text { Consumption (Gal) }\end{array}$ & $\begin{array}{c}\text { Percent Used For } \\
\text { Rotational Training }\end{array}$ \\
\hline Gasoline & 446,098 & $30 \%^{\text {(a) }}$ \\
\hline Diesel & $3,718,042$ & $74 \%^{(a)}$ \\
\hline JP-4 & 770,500 & $63 \%^{(a)}$ \\
\hline JP-8 & $1,367,750$ & $69 \%^{(a)}$ \\
\hline
\end{tabular}

(a) The balance of consumption is used for standard operations not associated with specific rotational unit use. 


\subsection{References}

Earley, M. W., et al. 1989. The National Electrical Code Handbook: Based on the 1990 Edition of the National Electrical Code. National Fire Protection Association, Quincy, Massachusetts.

Gönen, T. 1986. Electric Power Distribution System Engineering. Mc-Graw-Hill Book Company, New York, New York.

\subsection{Regional EUI Sources}

Commercial Sector Energy Use Simulation for Planning Area: BGP (Burbank, Glendale, Pasadena). 1989. California Energy Commission.

Commercial Sector Energy Use Simulation for Planning Area: LADWP (Los Angeles Department of Water and Power). 1989. California Energy Commission.

Commercial Sector Energy Use Simulation for Planning Area: PG\&E (Pacific Gas and Electric). 1989. California Energy Commission.

Commercial Sector Energy Use Simulation for Planning Area: SCED (Southern California Edison). 1989. California Energy Commission.

Household Energy Consumption and Expenditure 1987 (RECS). 1987. Energy Information Administration.

Nonresidential Building Energy Consumption Survey: Commercial Buildings Consumption and Expenditure 1986 (CBECS). 1986. Energy Information Administration.

EPA Regional Commercial and Residential End-Use Data: WSCC (Western Systems Coordinating Council). 1986. Environmental Protection Agency. 

Appendix A

Transmission and Distribution System 



\section{Appendix A}

\section{Transmission and Distribution System}

Most of the transmission and distribution system energy losses at Fort Irwin are due to transformer losses. Transformers are necessary to convert high voltage distribution power to low voltage utilization power. The total combined losses for the approximately 610 Fort Irwin distribution transformers account for about 2.4 million $\mathrm{kWh}$ of annual energy losses, contributing approximately $273 \mathrm{~kW}$ to the peak demand. The methodology for calculating this consumption is given in this appendix. Transformer loss calculations were done using incomplete data. In some cases, the number of phases, primary or secondary voltages were unavailable. In these cases, the losses were extrapolated from the average losses calculated for the known data. Unavailable data in the tables are denoted by a "-".

\section{A.1 Transformer Loss Methodology}

Transformer energy loss consists of no-load and load power losses. No-load loss is the energy consumed by the transformer's magnetic field during periods when the transformer is energized. It is dependent on the configuration and design of the device, materials used, and the voltage and frequency of the power. These characteristics remain constant during the loading cycle and, therefore, do not change with transformer load (typically measured in kVA).

Load losses, on the other hand, are produced from resistance in the conductor windings. These losses are a function of the total transformer current, and vary as a function of the square of the transformer load.

\section{A.2 Transformer Loss Characteristics}

Table A.1 lists typical no-load and load losses for transformer sizes at Fort Irwin. These data were extrapolated from data contained in Gönen (1986), with interpolation and extrapolation for those sizes not included in Gönen. The load loss given in the table represents operation at full nameplate capacity, as measured in kVA. Loss values for transformers where phase or voltage information was missing were estimated by assuming similar characteristics to other transformers of the same or similar sizes.

\section{A.2.1 Peak Power Loss}

Transformer loss calculations include both the peak power demand and the annual energy consumption. This distinction is particularly important to assess the impact to the overall electrical consumption, since both demand and energy are billed separately.

The peak transformer demand includes the no-load and load losses. Since transformer loss is a function of load, the maximum transformer loss is coincident with the peak load consumed by Fort Irwin. 
Table A.1. Individual Transformer Losses by Size

\begin{tabular}{|c|c|c|c|c|}
\hline \multirow{2}{*}{$\begin{array}{l}\text { No. of } \\
\text { Phases }\end{array}$} & \multirow[b]{2}{*}{$\begin{array}{l}\text { Voltage } \\
\text { Prim/Sec }\end{array}$} & \multirow[b]{2}{*}{$\begin{array}{l}\text { Capacity } \\
\text { (kVA) }\end{array}$} & \multicolumn{2}{|c|}{ Loss (Watts) } \\
\hline & & & No-Load & Load \\
\hline 1 & $120 / 240$ & 5 & 41 & 103 \\
\hline 1 & $120 / 240$ & 10 & 68 & 136 \\
\hline 1 & $120 / 240$ & 15 & 84 & 198 \\
\hline 1 & $120 / 240$ & 25 & 118 & 304 \\
\hline 1 & $120 / 240$ & 37.5 & 166 & 404 \\
\hline 1 & $120 / 240$ & 50 & 185 & 535 \\
\hline 1 & $120 / 240$ & 75 & 285 & 700 \\
\hline 1 & $120 / 240$ & 100 & 355 & 920 \\
\hline 1 & $120 / 240$ & 167 & 500 & 1600 \\
\hline 1 & $-/ 480$ & 10 & 68 & 141 \\
\hline 3 & $34.5 \mathrm{k} / 12 \mathrm{k}$ & 7500 & 11600 & 50600 \\
\hline 3 & $120 / 208$ & 10 & 88 & 247 \\
\hline 3 & $120 / 208$ & 15 & 106 & 280 \\
\hline 3 & $120 / 208$ & 25 & 149 & 430 \\
\hline 3 & $120 / 208$ & 37.5 & 198 & 585 \\
\hline 3 & $120 / 208$ & 45 & 223 & 683 \\
\hline 3 & $120 / 208$ & 50 & 246 & 734 \\
\hline 3 & $120 / 208$ & 75 & 360 & 990 \\
\hline 3 & $120 / 208$ & 100 & 445 & 1130 \\
\hline 3 & $120 / 208$ & 112.5 & 530 & 1270 \\
\hline 3 & $120 / 208$ & 150 & 560 & 1690 \\
\hline 3 & $120 / 208$ & 225 & 880 & 2420 \\
\hline 3 & $120 / 208$ & 300 & 1050 & 3250 \\
\hline 3 & $120 / 208$ & 500 & 1600 & 5200 \\
\hline 3 & $120 / 240$ & 10 & 68 & 136 \\
\hline 3 & $120 / 240$ & 15 & 84 & 198 \\
\hline
\end{tabular}


Table A.1. (contd)

\begin{tabular}{|c|c|c|c|c|}
\hline \multirow{2}{*}{$\begin{array}{l}\text { No. of } \\
\text { Phases } \\
\end{array}$} & \multirow[b]{2}{*}{$\begin{array}{l}\text { Voltage } \\
\text { Prim/Sec }\end{array}$} & \multirow[b]{2}{*}{$\begin{array}{c}\text { Capacity } \\
\text { (kVA) }\end{array}$} & \multicolumn{2}{|c|}{ Loss (Watts) } \\
\hline & & & No-Load & Load \\
\hline 3 & $120 / 240$ & 25 & 118 & 304 \\
\hline 3 & $120 / 240$ & 37.5 & 166 & 404 \\
\hline 3 & $120 / 240$ & 50 & 185 & 535 \\
\hline 3 & $120 / 240$ & 100 & 355 & 920 \\
\hline 3 & $120 / 240$ & 167 & 500 & 1600 \\
\hline 3 & $120 / 240$ & 300 & 749 & 3202 \\
\hline 3 & $-/ 240$ & 10 & 68 & 136 \\
\hline 3 & $-/ 240$ & 25 & 118 & 304 \\
\hline 3 & $2400 / 4160$ & 100 & 416 & 798 \\
\hline 3 & $277 / 480$ & 15 & 87 & 242 \\
\hline 3 & $277 / 480$ & 25 & 144 & 403 \\
\hline 3 & $277 / 480$ & 37.5 & 370 & 600 \\
\hline 3 & $277 / 480$ & 112.5 & 530 & 1270 \\
\hline 3 & $277 / 480$ & 300 & 1050 & 3050 \\
\hline 3 & $277 / 480$ & 500 & 1600 & 4900 \\
\hline 3 & $277 / 480$ & 750 & 1800 & 7600 \\
\hline 3 & $-/ 480$ & 10 & 68 & 141 \\
\hline 3 & $-/ 480$ & 15 & 84 & 203 \\
\hline 3 & $-/ 480$ & 25 & 118 & 309 \\
\hline 3 & $-/ 480$ & 37.5 & 166 & 409 \\
\hline 3 & $-/ 480$ & 50 & 234 & 748 \\
\hline 3 & $-/ 480$ & 75 & 360 & 990 \\
\hline 3 & $-/ 480$ & 100 & 473 & 177 \\
\hline 3 & $-/ 480$ & 112.5 & 530 & 1270 \\
\hline 3 & $-/ 480$ & 167 & 633 & 3212 \\
\hline 3 & $-/ 480$ & 225 & 880 & 2420 \\
\hline
\end{tabular}


Table A.1. (contd)

\begin{tabular}{||c|l|c|c|c||}
\hline \hline \multicolumn{3}{||c|}{} & \multicolumn{2}{c||}{ Loss (Watts) } \\
\hline $\begin{array}{c}\text { No. of } \\
\text { Phases }\end{array}$ & $\begin{array}{c}\text { Voltage } \\
\text { Prim/Sec }\end{array}$ & $\begin{array}{c}\text { Capacity } \\
\text { (kVA) }\end{array}$ & No-Load & Load \\
\hline 3 & $-/ 480$ & 500 & 1600 & 4900 \\
\hline 3 & $-/-$ & 15 & 106 & 280 \\
\hline 3 & $-/-$ & 25 & 149 & 430 \\
\hline 3 & $-/-$ & 37.5 & 166 & 404 \\
\hline 3 & $-/-$ & 50 & 185 & 535 \\
\hline 3 & $-/-$ & 75 & 360 & 990 \\
\hline 3 & $-/-$ & 150 & 560 & 1690 \\
\hline 3 & $-/-$ & 500 & 1600 & 5200 \\
\hline- & $-/-$ & 10 & 68 & 136 \\
\hline- & $-/-$ & 25 & 149 & 430 \\
\hline- & $-/-$ & 37.5 & 166 & 404 \\
\hline
\end{tabular}

The transformer load loss given in Table A.1 represents the loss at nameplate capacity. Since the peak load is normally quite different than the transformer capacity, the actual loss must be adjusted accordingly. Equation (A.1) gives the formula for calculating the demand loss factor $\left(\mathrm{F}_{\mathrm{DLs}}\right)$, used to adjust the transformer loss during peak loading as opposed to nameplate capacity operation. Since the load loss is primarily resistive losses in the windings, this equation is based on the $I^{2} R$ nature of resistive loss.

$$
F_{D L S}=\left(\frac{\text { Peak Load (kVA) X div. factor }}{\text { Nameplate Capacity (kVA) }}\right)^{2}
$$

\section{A.2.2 Annual Energy Loss}

To calculate the total annual energy loss of the transformers, both the no-load and load contributions must be properly accounted for. The no-load energy consumption is the no-load loss multiplied by the number of hours in the year. The load loss contribution must include the variations in the load. Variations in electrical consumption at Fort Irwin exist both seasonally (primarily summer/winter) and hourly (within 24 hour day). An equation based on empirical data, developed in Gönen (1986), correlates the average transformer loss with the average and peak loads of the system. This formula takes into consideration the $I^{2} R$ nature of the resistive loss and typical characteristics of daily load variations (within 24 
hour day). The equation is then modified to account for the difference between peak load and nameplate capacity. The energy loss factor $\left(F_{E L S}\right)$ is now given by Equation (A.2).

$$
F_{E L S}=F_{D L S}\left(0.3 F_{L D}+0.7 F_{L D}^{2}\right)
$$

where $F_{\mathrm{LD}}=$ Load Factor $=\frac{\text { Average Load }(\mathrm{kW})}{\text { Peak Load }(\mathrm{kW})}$

\section{A.3 Fort Irwin Transformer Losses}

For the transformers at Fort Irwin, average and peak loads for summer and winter were derived based on peak billed $\mathrm{kW}$ and total transformer nameplate capacity. Power factors were calculated for each season based on the reported kVAR values from utility billing records. These were found to be 0.8965 for summer and 0.9071 for winter. The load factors were based on the calculated average load for the season divided by the billed peak load. The demand and energy loss factors are given in Table A.2.

A diversity (ratio between the individual maximum demands and the coincident maximum demand) factor of 2.0 was applied to all transformers based on the National Electric Code diversity factor allowances (Earley et al. 1989). The equations for calculating the overall contribution of transformer losses on the Fort Irwin peak power demand and annual energy consumption are given below in Equations (A.3) and (A.4).

$$
\begin{array}{cc}
\text { Peak Power Loss }=\mathrm{NLL}+\mathrm{F}_{\mathrm{DLS}} \mathrm{LL} & \text { Watts } \\
\text { Annual Energy Loss }=8.76\left(\mathrm{NLL}+\mathrm{F}_{\mathrm{ELS}} \mathrm{LL}\right) & \mathrm{kWh} / \text { year }
\end{array}
$$

where NLL $=$ Transformer no-load loss (watts)

$\mathrm{LL}=$ Transformer load loss (watts)

Table A.2. Loss Factors for Fort Irwin Transformers

\begin{tabular}{||l|c|c|c|c|c||}
\hline \hline Season & $\begin{array}{c}\text { Peak Load } \\
\text { (MW) }\end{array}$ & $\begin{array}{c}\text { Power } \\
\text { Factor }\end{array}$ & $\begin{array}{c}\text { Demand } \\
\text { Loss Factor }\end{array}$ & $\begin{array}{c}\text { Load } \\
\text { Factor }\end{array}$ & $\begin{array}{c}\text { Energy } \\
\text { Loss Factor }\end{array}$ \\
\hline Summer & 16.838 & 0.8965 & 1.140 & 0.135 & 0.0605 \\
\hline Winter & 10.714 & 0.9071 & 0.451 & 0.157 & 0.0290 \\
\hline
\end{tabular}


The total transformer power and energy consumption for Fort Irwin, aggregated by transformer size, is given in Table A.3.

Table A.3. Fort Irwin Transformer Power Consumption by Size

\begin{tabular}{|c|c|c|c|c|c|c|c|}
\hline \multirow[b]{2}{*}{$\begin{array}{l}\text { No. } \\
\text { Phase }\end{array}$} & \multirow[b]{2}{*}{$\begin{array}{r}\text { Voltage } \\
\text { Prim/Sec }\end{array}$} & \multirow[b]{2}{*}{ Capacity (kVA) } & \multirow[b]{2}{*}{$\begin{array}{c}\text { No. } \\
\text { Units }\end{array}$} & \multicolumn{2}{|c|}{ Energy } & \multicolumn{2}{|c|}{ Demand } \\
\hline & & & & Summer $(\mathbf{k W h})$ & Winter (kWh) & Summer $(\mathrm{kW})$ & Winter (kW) \\
\hline 1 & $120 / 240$ & 5 & 2 & 494 & 426 & 0.3 & 0.2 \\
\hline 1 & $120 / 240$ & 10 & 25 & 9,680 & 8,542 & 5.6 & 3.2 \\
\hline 1 & $120 / 240$ & 15 & 36 & 17,928 & 15,543 & 11.2 & 6.2 \\
\hline 1 & $120 / 240$ & 25 & 14 & 10,032 & 8,608 & 6.5 & 3.6 \\
\hline 1 & $120 / 240$ & 37.5 & 35 & 34,737 & 30,005 & 21.9 & 12.2 \\
\hline 1 & $120 / 240$ & 50 & 54 & 62,735 & 53,068 & 42.9 & 23.0 \\
\hline 1 & $120 / 240$ & 75 & 52 & 88,824 & 76,644 & 56.3 & 31.2 \\
\hline 1 & $120 / 240$ & 100 & 29 & 62,619 & 53,692 & 40.7 & 22.3 \\
\hline 1 & $120 / 240$ & 167 & 8 & 25,929 & 21,646 & 18.6 & 9.8 \\
\hline 1 & $-/ 480$ & 10 & 2 & 781 & 687 & 0.5 & 0.3 \\
\hline 1 & $-1-$ & 59 & 1 & 1,162 & 983 & 0.8 & 0.4 \\
\hline 3 & $34.5 \mathrm{k} / 12 \mathrm{k}$ & 7500 & 5 & 420,247 & 335,588 & 346.5 & 172.1 \\
\hline 3 & $120 / 208$ & 10 & 30 & $16, \overline{431}$ & 13,952 & 11.1 & 6.0 \\
\hline 3 & $120 / 208$ & 15 & 24 & 15,557 & 13,309 & 10.2 & 5.6 \\
\hline 3 & $120 / 208$ & 25 & 51 & 47,690 & 40,352 & 32.6 & 17.5 \\
\hline 3 & $120 / 208$ & 37.5 & 12 & 15,019 & 12,670 & 10.4 & 5.5 \\
\hline 3 & $120 / 208$ & 45 & 1 & $1, \overline{425}$ & 1,197 & 1.0 & 0.5 \\
\hline 3 & $120 / 208$ & 50 & 15 & 23,395 & 19,711 & 16.2 & 8.7 \\
\hline 3 & $120 / 208$ & 75 & 10 & 22,272 & 18,959 & 14.9 & 8.1 \\
\hline 3 & $120 / 208$ & 100 & 9 & 24,223 & 20,820 & 15.6 & 8.6 \\
\hline 3 & $120 / 208$ & 112.5 & 2 & 6,311 & 5,462 & 4.0 & 2.2 \\
\hline 3 & $120 / 208$ & 150 & 2 & 7,126 & 5,995 & 5.0 & 2.6 \\
\hline 3 & $120 / 208$ & 225 & 3 & 16,333 & 13,903 & 10.9 & 5.9 \\
\hline 3 & $120 / 208$ & 300 & 4 & 26,936 & 22,586 & 19.0 & 10.1 \\
\hline 3 & $120 / 208$ & 500 & 1 & 10,424 & 8,684 & 7.5 & 3.9 \\
\hline 3 & $120 / 240$ & 10 & 6 & 2,323 & 2,050 & 1.3 & 0.8 \\
\hline 3 & $120 / 240$ & 15 & 11 & 5,478 & 4,749 & 3.4 & 1.9 \\
\hline 3 & $120 / 240$ & 25 & 9 & 6,449 & 5,533 & 4.2 & 2.3 \\
\hline 3 & $120 / 240$ & 37.5 & 1 & 992 & 857 & 0.6 & 0.3 \\
\hline 3 & $120 / 240$ & 50 & 2 & $2, \overline{324}$ & 1,965 & 1.6 & 0.9 \\
\hline 3 & $120 / 240$ & 100 & $\overline{2}$ & 4,319 & 3,703 & 2.8 & 1.5 \\
\hline 3 & $120 / 240$ & 167 & 1 & 3,241 & 2,706 & 2.3 & 1.2 \\
\hline$\overline{3}$ & $120 / 240$ & 300 & 1 & 5,384 & $\overline{4,313}$ & 4.4 & 2.2 \\
\hline 3 & -1240 & 10 & 6 & 2,323 & 2,050 & 1.3 & 0.8 \\
\hline 3 & -1240 & 25 & $\overline{3}$ & 2,150 & 1,844 & 1.4 & 0.8 \\
\hline 3 & $2400 / 4160$ & 100 & 3 & 7,039 & 6,238 & 4.0 & 2.3 \\
\hline 3 & $277 / 480$ & 15 & $\overline{12}$ & 6,480 & 5,509 & 4.4 & 2.4 \\
\hline 3 & $277 / 480$ & 25 & 3 & 2,686 & 2,282 & 1.8 & 1.0 \\
\hline 3 & $277 / 480$ & 37.5 & 3 & 6,044 & 5,442 & 3.2 & 1.9 \\
\hline 3 & $277 / 480$ & 112.5 & 1 & 3,156 & 2,731 & 2.0 & 1.1 \\
\hline 3 & $277 / 480$ & 300 & 3 & 19,808 & 16,746 & 13.6 & 7.3 \\
\hline 3 & $277 / 480$ & 500 & 6 & 61,362 & 51,524 & 43.1 & 22.9 \\
\hline 3 & $277 / 480$ & 750 & 2 & 25,754 & 20,667 & 20.9 & 10.5 \\
\hline 3 & -1480 & 10 & 3 & 1,171 & 1,030 & 0.7 & 0.4 \\
\hline
\end{tabular}


Table A.3. (contd)

\begin{tabular}{|c|c|c|c|c|c|c|c|}
\hline \multirow{2}{*}{$\begin{array}{c}\text { No. } \\
\text { Phase }\end{array}$} & \multirow{2}{*}{$\begin{array}{r}\text { Voltage } \\
\text { Prim/Sec }\end{array}$} & \multirow[b]{2}{*}{ Capacity (kVA) } & \multirow[b]{2}{*}{$\begin{array}{c}\text { No. } \\
\text { Units }\end{array}$} & \multicolumn{2}{|c|}{ Energy } & \multicolumn{2}{|c|}{ Demand } \\
\hline & & & & Summer (kWh) & Winter (kWh) & Summer (kW) & Winter $(\mathbf{k W})$ \\
\hline 3 & -1480 & 15 & 6 & 3,008 & 2,600 & 1.9 & 1.1 \\
\hline 3 & -1480 & 25 & 21 & 15,117 & 12,945 & 9.9 & 5.4 \\
\hline 3 & $-/ 480$ & 37.5 & 9 & 8,962 & 7,730 & 5.7 & 3.2 \\
\hline 3 & -1480 & 50 & 16 & 24,261 & 20,256 & 17.4 & 9.1 \\
\hline 3 & $-/ 480$ & 75 & 3 & 6,682 & 5,688 & 4.5 & 2.4 \\
\hline 3 & -1480 & 100 & 3 & 6,564 & 6,386 & 2.0 & 1.7 \\
\hline 3 & -1480 & 112.5 & 1 & 3,156 & 2,731 & 2.0 & 1.1 \\
\hline 3 & -1480 & 167 & 3 & 14,648 & 11,424 & 12.9 & 6.2 \\
\hline 3 & -1480 & 225 & 1 & 5,444 & 4,634 & 3.6 & 2.0 \\
\hline 3 & -1480 & 500 & 1 & 10,227 & 8,587 & 7.2 & 3.8 \\
\hline 3 & $-1-$ & 15 & 3 & 1,945 & 1,664 & 1.3 & 0.7 \\
\hline 3 & $-1-$ & 25 & 3 & 2,805 & 2,374 & 1.9 & 1.0 \\
\hline 3 & $-1-$ & 37.5 & 3 & 2,977 & 2,572 & 1.9 & 1.0 \\
\hline 3 & $-1-$ & 50 & 3 & 3,485 & 2,948 & 2.4 & 1.3 \\
\hline 3 & $-1-$ & 59 & 12 & 17,105 & 14,363 & 12.0 & 6.4 \\
\hline 3 & $-1-$ & 75 & $\overline{3}$ & 6,682 & 5,688 & 4.5 & 2.4 \\
\hline 3 & $-1-$ & 150 & 1 & 3,563 & 2,998 & 2.5 & 1.3 \\
\hline 3 & $-1-$ & 500 & $\overline{2}$ & 20,848 & 17,368 & 15.1 & 7.9 \\
\hline - & $-1-$ & 10 & 2 & 774 & 683 & 0.4 & 0.3 \\
\hline- & $-1-$ & 25 & 1 & 935 & 791 & 0.6 & 0.3 \\
\hline- & $-1-$ & 37.5 & 1 & 992 & 857 & 0.6 & 0.3 \\
\hline- & $-1-$ & 59 & 7 & 8,132 & 6,879 & 5.6 & 3.0 \\
\hline Totals: & - & 14,638 & 610 & $1,305,107$ & $1,087,136$ & 942.9 & 493.9 \\
\hline
\end{tabular}



Appendix B

EUI Data Sources 



\section{Appendix B}

\section{EUI Data Sources}

Tables B.1 through B.24 show the various EUI values obtained from a number of sources. Tables B. 25 and B.26 show the initial EUI values applied to the Fort Irwin analysis (see Section 3.2 for final site-specific EUI values).

B. 1 
Table B.1. Small Office - Electric $\left(\mathrm{kWh} / \mathrm{ft}^{2}-\mathrm{yr}\right)$

\begin{tabular}{||l|r|r|r|r|r|r|r|r|r|r|r||}
\hline \hline & Heat & Cool & Vent & DHW & Cook & Refrig. & $\begin{array}{c}\text { Int. } \\
\text { Lgt. }\end{array}$ & $\begin{array}{c}\text { Ext. } \\
\text { Lgt. }\end{array}$ & $\begin{array}{c}\text { Office } \\
\text { Equip. }\end{array}$ & Other(a) & Total \\
\hline PG\&E & .07 & 3.67 & 1.39 & .19 & .2 & .21 & 4.47 & 1.0 & 3.14 & 3.19 & 17.53 \\
\hline SCE & .03 & 3.52 & .87 & .2 & .26 & .26 & 4.83 & .93 & 2.82 & 2.48 & 16.20 \\
\hline LADWP & .05 & 3.72 & .94 & .21 & .27 & .28 & 5.06 & 1.04 & 3.24 & 3.61 & 18.42 \\
\hline BGP & .1 & 4.64 & 1.12 & .22 & .27 & .27 & 4.93 & 2.75 & 2.46 & 1.2 & 17.96 \\
\hline EPA/WSCC & 9.3 & 6.7 & 1.8 & 1.3 & .6 & .2 & $8.6^{(0)}$ & - & - & 3.1 & 31.6 \\
\hline CBECS & - & - & - & - & - & - & - & - & - & - & - \\
\hline \\
$\begin{array}{l}\text { (a) Defined as miscellaneous/other EUI. } \\
\text { (b) Number includes interior and exterior lighting. }\end{array}$ \\
\hline
\end{tabular}

Table B.2. Large Office - Electric $\left(\mathrm{kWh} / \mathrm{ft}^{2}-\mathrm{yr}\right)$

\begin{tabular}{|l|r|r|r|r|r|r|r|r|r|r|r||}
\hline \hline & Heat & Cool & Vent & DHW & Cook & Refrig. & $\begin{array}{c}\text { Int. } \\
\text { Lgt. }\end{array}$ & $\begin{array}{c}\text { Ext. } \\
\text { Lgt. }\end{array}$ & $\begin{array}{c}\text { Office } \\
\text { Equip. }\end{array}$ & Other(o) & Total \\
\hline PG\&E & 3.41 & 3.7 & 3.74 & .31 & .09 & .1 & 7.79 & 1.21 & 3.2 & 2.66 & 26.21 \\
\hline SCE. & 3.14 & 5.5 & 3.01 & .33 & .1 & .11 & 8.08 & .93 & 2.25 & 1.82 & 25.27 \\
\hline LADWP & 2.88 & 5.77 & 3.22 & .33 & .11 & .11 & 8.25 & 1.91 & 3.44 & 3.0 & 28.3 \\
\hline BGP & 3.14 & 5.32 & 3.19 & .34 & .1 & .11 & 8.21 & 1.57 & 1.97 & 2.48 & 26.43 \\
\hline EPA/WSCC & 5.2 & 6.8 & 2.8 & 1.4 & .5 & .3 & $7.5^{(0)}$ & - & - & 4.1 & 28.6 \\
\hline CBECS & - & - & - & - & - & - & - & - & - & 22.7 & - \\
\hline $\begin{array}{l}\text { (a) Defined as miscellaneous/other EUI. } \\
\text { (b) Number includes interior and exterior lighting. }\end{array}$ \\
\hline
\end{tabular}


Table B.3. Restaurant - Electric $\left(\mathrm{kWh} / \mathrm{ft}^{2}-\mathrm{yr}\right)$

\begin{tabular}{|c|c|c|c|c|c|c|c|c|c|c|c|}
\hline & Heat & Cool & Vent & DHW & Cook & Refrig. & $\begin{array}{l}\text { Int. } \\
\text { Lgt. }\end{array}$ & $\begin{array}{l}\text { Ext. } \\
\text { Lgt. }\end{array}$ & $\begin{array}{l}\text { Office } \\
\text { Equip. }\end{array}$ & Other ${ }^{(a)}$ & Total \\
\hline PG\&E & 3.02 & 4.32 & 7.66 & 1.0 & 4.24 & 9.94 & 6.95 & 2.56 & 0.5 & 4.45 & 44.19 \\
\hline SCE & 1.63 & 6.2 & 5.7 & .41 & 4.58 & 10.7 & 6.94 & 2.1 & .05 & 3.3 & 41.61 \\
\hline LADWP & 1.7 & 6.84 & 5.94 & .88 & 4.67 & 10.93 & 7.34 & 1.91 & .06 & 4.14 & 44.14 \\
\hline BGP & 1.67 & 6.39 & 5.97 & 1.72 & 4.89 & 10.59 & 7.32 & 4.09 & .01 & 5.13 & 47.78 \\
\hline EPA/WSCC & 10.3 & 6.1 & 2.2 & 12.8 & 21.7 & 6.4 & $6.1^{(b)}$ & - & - & 2.4 & 68.0 \\
\hline CBECS & - & - & - & - & - & - & - & - & - & -- & 30.2 \\
\hline $\begin{array}{l}\text { (a) Defined } \\
\text { (b) Number }\end{array}$ & . & ous & EUI. & Ghing & & & & & & & \\
\hline
\end{tabular}

Table B.4. Retail - Electric $\left(\mathrm{kWh} / \mathrm{ft}^{2}-\mathrm{yr}\right)$

\begin{tabular}{|c|c|c|c|c|c|c|c|c|c|c|c|}
\hline & Heat & Cool & Vent & DHW & Cook & Refrig. & $\begin{array}{l}\text { Int. } \\
\text { Lgt. }\end{array}$ & $\begin{array}{l}\text { Ext. } \\
\text { Lgt. }\end{array}$ & $\begin{array}{l}\text { Office } \\
\text { Equip. }\end{array}$ & Other ${ }^{(a)}$ & Total \\
\hline PG\&E & .28 & 1.77 & 1.86 & .07 & .12 & .78 & 5.29 & .92 & .33 & .89 & 12.31 \\
\hline SCE & .17 & 2.75 & 1.46 & .1 & .16 & .88 & 5.78 & .91 & .21 & .75 & 13.17 \\
\hline LADWP & .11 & 2.38 & 1.49 & .09 & .16 & .9 & 5.57 & .82 & .32 & .94 & 12.78 \\
\hline BGP & .12 & 2.94 & 1.54 & .11 & .16 & .88 & 5.84 & 1.24 & .6 & .87 & 14.3 \\
\hline EPA/WSCC & 4.1 & 1.0 & 1.3 & .7 & 1.2 & .7 & $5.4^{(b)}$ & - & - & 1.3 & 15.7 \\
\hline CBECS & - & - & - & - & - & -- & - & - & - & - & 12.2 \\
\hline $\begin{array}{l}\text { (a) Defined } \\
\text { (b) Number }\end{array}$ & $\begin{array}{l}\text { iscell } \\
\text { udes } \mathrm{i}\end{array}$ & ous/c & $\begin{array}{l}\text { EUI. } \\
\text { xterio }\end{array}$ & hiting. & & & & & & & \\
\hline
\end{tabular}


Table B.5. Food Store - Electric $\left(\mathrm{kWh} / \mathrm{ft}^{2}-\mathrm{yr}\right)$

\begin{tabular}{|c|c|c|c|c|c|c|c|c|c|c|c|}
\hline & Heat & Cool & Vent & DHW & Cook & Refrig. & $\begin{array}{l}\text { Int. } \\
\text { Lgt. }\end{array}$ & $\begin{array}{l}\text { Ext. } \\
\text { Lgt. }\end{array}$ & $\begin{array}{l}\text { Office } \\
\text { Equip. }\end{array}$ & Other ${ }^{(a)}$ & Total \\
\hline PG\&E & 1.29 & 1.11 & 2.31 & .14 & .62 & 17.49 & 9.91 & 1.44 & .36 & 1.79 & 36.46 \\
\hline SCE & .79 & 1.06 & 1.92 & .18 & .8 & 21.12 & 10.88 & 1.43 & .33 & 1.51 & 40.02 \\
\hline LADWP & .74 & 1.08 & 1.94 & .19 & .81 & 21.8 & 11.11 & 1.27 & .35 & 1.91 & 41.2 \\
\hline BGP & .62 & 1.7 & 1.87 & .2 & .84 & 20.41 & 10.86 & 1.92 & .65 & 1.78 & 40.85 \\
\hline EPA/WSCC & 13.3 & 3.8 & 3.2 & 2.9 & 12.1 & 23.7 & $12.6^{(\mathrm{b})}$ & - & - & 1.9 & 73.5 \\
\hline CBECS & - & - & - & - & - & - & - & - & - & - & - \\
\hline
\end{tabular}

(a) Defined as miscellaneous/other EUI.

(b) Number includes interior and exterior lighting.

Table B.6. Warehouse - Electric $\left(\mathrm{kWh} / \mathrm{ft}^{2}-\mathrm{yr}\right)$

\begin{tabular}{|c|c|c|c|c|c|c|c|c|c|c|c|}
\hline & Heat & Cool & Vent & DHW & Cook & Refrig. & $\begin{array}{l}\text { Int. } \\
\text { Lgt. }\end{array}$ & $\begin{array}{l}\text { Ext. } \\
\text { Lgt. }\end{array}$ & $\begin{array}{l}\text { Office } \\
\text { Equip. }\end{array}$ & Other ${ }^{(a)}$ & Total \\
\hline PG\&E & .25 & .7 & .69 & .05 & - & 1.43 & 3.07 & .17 & .26 & 1.46 & 8.08 \\
\hline SCE & .19 & .83 & .56 & .06 & - & 1.55 & 3.2 & .16 & .14 & 1.16 & 7.85 \\
\hline LADWP & .19 & .84 & .57 & .06 & - & 1.44 & 3.25 & .2 & .24 & 1.78 & 8.57 \\
\hline BGP & .12 & .95 & .6 & .06 & - & 1.57 & 3.24 & .21 & .46 & 1.3 & 8.51 \\
\hline EPA/WSCC & 1.5 & 1.4 & 1.0 & .7 & - & 6.1 & $2.7^{(b)}$ & - & - & .9 & 14.3 \\
\hline CBECS & - & - & - & - & - & - & - & - & - & - & 7.7 \\
\hline
\end{tabular}

(a) Defined as miscellaneous/other EUI.

(b) Number includes interior and exterior lighting. 
Table B.7. Elementary School - Electric $\left(\mathrm{kWh} / \mathrm{ft}^{2}-\mathrm{yr}\right)$

\begin{tabular}{|c|c|c|c|c|c|c|c|c|c|c|c|}
\hline & Heat & Cool & Vent & DHW & Cook & Refrig. & $\begin{array}{l}\text { Int. } \\
\text { Lgt. }\end{array}$ & $\begin{array}{l}\text { Ext. } \\
\text { Lgt. }\end{array}$ & $\begin{array}{l}\text { Office } \\
\text { Equip. }\end{array}$ & Other $r^{(a)}$ & Total \\
\hline PG\&E & 1.21 & 2.15 & 1.13 & .58 & .3 & .17 & 2.88 & .75 & .48 & .41 & 10.06 \\
\hline SCE & 1.27 & 2.0 & .75 & .57 & .29 & .18 & 2.77 & .41 & .4 & .21 & 8.85 \\
\hline LADWP & 1.0 & 2.26 & .81 & .55 & .32 & .19 & 2.87 & .52 & .65 & .36 & 9.53 \\
\hline BGP & .98 & 2.03 & .87 & .42 & .32 & .18 & 2.86 & 1.12 & .28 & .44 & 9.5 \\
\hline EPA/WSCC & 7.2 & 1.7 & .6 & 2.9 & 1.9 & .4 & $4.3^{(b)}$ & - & - & .6 & 19.6 \\
\hline CBECS & - & - & - & - & - & - & - & - & - & - & 8.23 \\
\hline
\end{tabular}

(a) Defined as miscellaneous/other EUI.

(b) Number includes interior and exterior lighting.

Table B.8. University/College - Electric $\left(\mathrm{kWh} / \mathrm{ft}^{2}-\mathrm{yr}\right)$

\begin{tabular}{||l|c|c|c|c|c|c|c|c|c|c|c|}
\hline & Heat & Cool & Vent & DHW & Cook & Refrig. & $\begin{array}{c}\text { Int. } \\
\text { Lgt. }\end{array}$ & $\begin{array}{c}\text { Ext. } \\
\text { Lgt. }\end{array}$ & $\begin{array}{c}\text { Office } \\
\text { Equip. }\end{array}$ & Other $\Gamma^{(a)}$ & Total \\
\hline PG\&E & 8.94 & 3.28 & 2.38 & 2.19 & .28 & 93 & 2.93 & .17 & 1.36 & 1.68 & 24.14 \\
\hline SCE & 4.14 & 4.3 & 1.75 & 2.41 & .3 & 1.04 & 2.89 & .1 & 1.68 & .9 & 19.51 \\
\hline LADWP & 1.31 & 3.99 & 1.85 & 2.07 & .32 & 1.06 & 2.65 & .11 & 1.92 & 1.32 & 16.6 \\
\hline BGP & 3.11 & 3.81 & 1.84 & 1.84 & .32 & .97 & 2.96 & .24 & .26 & 1.73 & 17.08 \\
\hline EPA/WSCC & 4.6 & 1.9 & 1.1 & 3.3 & 2.1 & .4 & $3.4^{(b)}$ & - & - & 1.0 & 17.8 \\
\hline CBECS & - & - & - & - & - & - & - & - & - & - & - \\
\hline
\end{tabular}

(a) Defined as miscellaneous/other EUI.

(b) Number includes interior and exterior lighting. 
Table B.9. Hospital - Electric $\left(\mathrm{kWh} / \mathrm{ft}^{2}-\mathrm{yr}\right)$

\begin{tabular}{|c|c|c|c|c|c|c|c|c|c|c|c|}
\hline & Heat & Cool & Vent & DHW & Cook & Refrig. & $\begin{array}{l}\text { Int. } \\
\text { Lgt. }\end{array}$ & $\begin{array}{l}\text { Ext. } \\
\text { Lgt. }\end{array}$ & $\begin{array}{l}\text { Office } \\
\text { Equip. }\end{array}$ & Other ${ }^{(a)}$ & Total \\
\hline PG\&E & 4.56 & 7.07 & 2.78 & 7.05 & .26 & .54 & 9.13 & .26 & 3.79 & 7.74 & 43.18 \\
\hline SCE & 3.46 & 9.55 & 2.3 & 7.94 & .31 & .6 & 9.94 & .26 & 2.88 & 6.63 & 43.87 \\
\hline LADWP & 1.33 & 11.25 & 2.31 & 8.23 & .31 & .61 & 9.45 & .16 & 4.73 & 5.8 & 44.18 \\
\hline BGP & 3.24 & 9.9 & 2.35 & 8.06 & .31 & .58 & 9.83 & .33 & 1.72 & 7.21 & 43.53 \\
\hline EPA/WSCC & 6.6 & 4.3 & 1.9 & 4.4 & 7.1 & .5 & $4.5^{(b)}$ & - & - & 1.9 & 31.2 \\
\hline CBECS & - & - & - & - & - & - & - & - & - & - & 13.24 \\
\hline
\end{tabular}

(a) Defined as miscellaneous/other EUI.

(b) Number includes interior and exterior lighting.

Table B.10. Hotel/Motel - Electric $\left(\mathrm{kWh} / \mathrm{ft}^{2}\right.$-yr)

\begin{tabular}{|c|c|c|c|c|c|c|c|c|c|c|c|}
\hline & Heat & Cool & Vent & DHW & Cook & Refrig. & $\begin{array}{l}\text { Int. } \\
\text { Lgt. }\end{array}$ & $\begin{array}{l}\text { Ext. } \\
\text { Lgt. }\end{array}$ & $\begin{array}{l}\text { Office } \\
\text { Equip. }\end{array}$ & Other ${ }^{(a)}$ & Total \\
\hline PG\&E & 7.15 & 3.75 & 1.33 & 2.24 & .5 & 1.82 & 3.73 & .05 & .02 & 2.34 & 22.93 \\
\hline SCE & 5.49 & 4.9 & .98 & 2.56 & .53 & 1.95 & 3.84 & .46 & .02 & 1.82 & 22.55 \\
\hline LADYP & 5.01 & 4.91 & 1.03 & 2.59 & .55 & 1.97 & 3.75 & .44 & .02 & 2.43 & 22.70 \\
\hline BGP & 4.27 & 5.43 & 1.08 & 2.62 & .56 & 1.92 & 3.87 & .64 & .03 & 2.14 & 22.56 \\
\hline EPA/WSCC & 2.7 & 5.4 & 1.1 & 5.2 & 16 & .9 & $4.0^{(b)}$ & - & - & 1.8 & 37.1 \\
\hline CBECS & - & - & - & - & - & - & - & - & - & - & 13.54 \\
\hline
\end{tabular}

(a) Defined as miscellaneous/other EUI.

(b) Number includes interior and exterior lighting. 
Table B.11. Miscellaneous - Electric $\left(\mathrm{kWh} / \mathrm{ft}^{2}-\mathrm{yr}\right)$

\begin{tabular}{|c|c|c|c|c|c|c|c|c|c|c|c|}
\hline & Heat & Cool & Vent & DHW & Cook & Refrig. & $\begin{array}{l}\text { Int. } \\
\text { Lgt. }\end{array}$ & $\begin{array}{l}\text { Ext. } \\
\text { Lgt. }\end{array}$ & $\begin{array}{l}\text { Office } \\
\text { Equip. }\end{array}$ & Other ${ }^{(a)}$ & Total \\
\hline PG\&E & 4.51 & 4.76 & 2.02 & .73 & .09 & .11 & 3.69 & .79 & .37 & .98 & 18.05 \\
\hline SCE & 3.29 & 5.1 & 1.56 & .79 & .1 & .12 & 3.68 & .61 & .15 & .68 & 16.08 \\
\hline LADWP & 3.27 & 5.59 & 1.62 & .8 & .1 & .12 & 3.75 & .69 & .45 & 1.04 & 17.43 \\
\hline BGP & 3.0 & 6.66 & 1.7 & .8 & .11 & .13 & 3.79 & 1.12 & .21 & 1.0 & 18.52 \\
\hline EPA/WSCC & 8.4 & 4.3 & 1.4 & .7 & 1.0 & 1.0 & $3.3^{(b)}$ & - & - & 1.4 & 21.5 \\
\hline CBECS & - & - & - & - & - & - & - & & - & - & 15.67 \\
\hline
\end{tabular}

(a) Defined as miscellaneous/other EUI.

(b) Number includes interior and exterior lighting.

Table B.12. Single Family Residence - Electric $\left(\mathrm{kWh} / \mathrm{ft}^{2}-\mathrm{yr}\right)$

\begin{tabular}{|c|c|c|c|c|c|c|c|c|c|c|c|}
\hline & Heat & Cool & Vent & DHW & Cook & Refrig. & $\begin{array}{l}\text { Int. } \\
\text { Lgt. }\end{array}$ & $\begin{array}{l}\text { Ext. } \\
\text { Lgt. }\end{array}$ & $\begin{array}{l}\text { Office } \\
\text { Equip. }\end{array}$ & Other ${ }^{(a)}$ & Total \\
\hline EPA/WSCC & 4.18 & .67 & - & 2.44 & .58 & - & - & - & - & 2.63 & 10.5 \\
\hline $\operatorname{RECS}^{(b)}$ & - & - & - & - & - & - & - & - & - & - & 9.36 \\
\hline
\end{tabular}


Table B.13. Small Office - Propane $\left(\mathrm{kWh} / \mathrm{ft}^{2}-\mathrm{yr}\right)$

\begin{tabular}{||l|r|r|r|r|r|r|c||}
\hline \hline & Heat & \multicolumn{1}{c|}{ Cool } & DHW & Cook & Refrig. & Other $^{(a)}$ & Total \\
\hline PG\&E & .5 & 82.58 & 1.67 & 5.98 & -- & 13.55 & 104.28 \\
\hline SCE & .18 & 82.66 & 1.18 & 5.19 & - & 12.66 & 101.87 \\
\hline LADWP & .27 & 75.33 & .73 & 4.94 & -- & 12.83 & 94.1 \\
\hline BGP & .72 & 106.07 & 1.73 & 5.91 & .52 & 13.36 & 128.31 \\
\hline EPA/WSCC & 48.9 & 13 & 5.9 & 1.3 & -- & .5 & 69.6 \\
\hline CBECS & -- & -- & - & -- & -- & -- & -- \\
\hline
\end{tabular}

(a) Defined as miscellaneous/other EUI.

Table B.14. Large Office - Propane $\left(\mathrm{kWh} / \mathrm{ft}^{2}-\mathrm{yr}\right)$

\begin{tabular}{||l|r|c|c|c|c|c|c||}
\hline & Heat & \multicolumn{1}{|c|}{ Cool } & DHW & Cook & Refrig. & Other ${ }^{(\mathrm{a})}$ & Total \\
\hline PG\&E & 38.12 & 98.3 & 6.4 & .52 & - & 10.74 & 154.08 \\
\hline SCE & 20.36 & 140.55 & 5.72 & .47 & 1.47 & 9.78 & 178.35 \\
\hline LADWP & 18.35 & 152.2 & 5.93 & .48 & 1.45 & 10.16 & 188.57 \\
\hline BGP & 23.84 & 142.56 & 6.35 & .52 & 1.46 & 10.67 & 185.4 \\
\hline EPA/WSCC & 36.1 & 59.1 & 8.9 & 2.0 & -- & .7 & 106.8 \\
\hline CBECS & -- & -- & - & -- & -- & - & 33.3 \\
\hline (a) Defined as miscellaneous/other EUI. & & & & \\
\hline
\end{tabular}


Table B.15. Restaurant - Propane $\left(\mathrm{kWh} / \mathrm{ft}^{2}-\mathrm{yr}\right)$

\begin{tabular}{||l|r|c|c|c|c|c|c||}
\hline & Heat & Cool & DHW & Cook & Refrig. & Other ${ }^{(a)}$ & Total \\
\hline PG\&E & 15.87 & 95.55 & 15.79 & 110.58 & - & 16.44 & 254.23 \\
\hline SCE & 7.61 & 145.8 & 13.97 & 98.43 & 33.14 & 14.99 & 313.94 \\
\hline LADWP & 3.36 & 153.84 & 12.96 & 102.61 & 33.29 & 15.27 & 321.33 \\
\hline BGP & 9.89 & 152.57 & 16.64 & 112.55 & 33.33 & 16.69 & 341.67 \\
\hline EPA/WSCC & 101.7 & 60.0 & 92.0 & 141.8 & - & - & 395.5 \\
\hline CBECS & -- & -- & -- & -- & - & -- & 189.4 \\
\hline (a) Defined as miscellaneous/other EUI. \\
\hline \multicolumn{7}{|l|}{} \\
\hline
\end{tabular}

Table B.16. Retail - Propane (kWh/ft $\left.{ }^{2}-\mathrm{yr}\right)$

\begin{tabular}{||l|r|c|c|c|c|c|c||}
\hline & \multicolumn{1}{|c|}{ Heat } & \multicolumn{1}{c|}{ Cool } & DHW & Cook & Refrig. & Other ${ }^{(a)}$ & Total \\
\hline PG\&E & 1.59 & 33.64 & .51 & .22 & - & 8.54 & 44.5 \\
\hline SCE & 1.01 & 61.85 & .43 & .17 & 7.39 & 7.97 & 78.82 \\
\hline LADWP & .54 & 59.93 & .4 & .14 & 7.39 & 7.94 & 76.34 \\
\hline BGP & .86 & 67.08 & .52 & .22 & 7.43 & 8.48 & 84.59 \\
\hline EPA/WSCC & 33.5 & 100.8 & 9.7 & 4.5 & -- & -- & 148.5 \\
\hline CBECS & -- & -- & -- & - & - & - & 26.2 \\
\hline (a) Defined as miscellaneous/other EUI. \\
\hline
\end{tabular}


Table B.17. Food Store - Propane $\left(\mathrm{kWh} / \mathrm{ft}^{2}-\mathrm{yr}\right)$

\begin{tabular}{||l|r|r|r|r|l|l|l||}
\hline & \multicolumn{1}{|c|}{ Heat } & \multicolumn{1}{c|}{ Cool } & DHW & Cook & Refrig. & Other ${ }^{(a)}$ & Total \\
\hline PG\&E & 14.89 & 22.22 & 1.05 & 6.25 & 105.65 & 27.25 & 177.31 \\
\hline SCE & 7.54 & 23.2 & .88 & 5.48 & -- & 25.65 & 62.75 \\
\hline LADWP & 5.88 & 21.89 & .55 & 4.81 & -- & 25.81 & 58.94 \\
\hline BGP & 8.34 & 33.89 & 1.05 & 6.29 & -- & 27.03 & 76.6 \\
\hline EPA/WSCC & 60.7 & 100.8 & 8.4 & 3.4 & - & -- & 72.5 \\
\hline CBECS & -- & -- & - & - & -- & -- & - \\
\hline
\end{tabular}

(a) Defined as miscellaneous/other EUI.

Table B.18. Warehouse - Propane $\left(\mathrm{kWh} / \mathrm{ft}^{2}-\mathrm{yr}\right)$

\begin{tabular}{||l|r|r|r|r|r|r|c||}
\hline & \multicolumn{1}{|c|}{ Heat } & \multicolumn{1}{c|}{ Cool } & DHW & Cook & Refrig. & Other ${ }^{(\mathrm{a})}$ & Total \\
\hline PG\&E & 1.35 & 12.36 & 1.01 & .09 & -- & 38.06 & 52.87 \\
\hline SCE & 16.16 & 15.19 & .9 & .08 & 4.7 & 35.94 & 72.97 \\
\hline LADWP & 15.34 & 17.72 & .61 & .09 & 4.7 & 37.14 & .75 .6 \\
\hline BGP & .72 & 18.67 & .98 & .09 & 4.73 & 37.14 & 62.93 \\
\hline EPA/WSCC & 19.5 & 2.8 & 2.1 & - & -- & 1.4 & 25.8 \\
\hline CBECS & -- & - & - & - & - & - & 13.2 \\
\hline (a) Defined as miscellaneous/other EUI. & & & & \\
\hline
\end{tabular}


Table B.19. Elementary School - Propane $\left(\mathrm{kWh} / \mathrm{ft}^{2}-\mathrm{yr}\right)$

\begin{tabular}{||l|c|c|c|c|c|c|c||}
\hline & Heat & Cool & DHW & Cook & Refrig. & Other $^{(a)}$ & Total \\
\hline PG\&E & 16.2 & 25.61 & 2.27 & .17 & - & 19.64 & 63.89 \\
\hline SCE & 10.03 & 23.45 & 2.05 & .13 & - & 17.57 & 53.23 \\
\hline LADWP & 7.62 & 25.37 & 2.12 & .13 & - & 18.09 & 53.33 \\
\hline BGP & 10.06 & 32.34 & 2.45 & .17 & 1.6 & 19.59 & 66.21 \\
\hline EPA/WSCC & 58 & 29.7 & 17.2 & 11.1 & - & 3.0 & 119 \\
\hline CBECS & - & -- & - & -- & -- & -- & 46.7 \\
\hline (a) Defined as miscellaneous/other EUI. & & & & \\
\hline
\end{tabular}

Table B.20. University/College - Propane (kWh/ $\left.\mathrm{ft}^{2}-\mathrm{yr}\right)$

\begin{tabular}{||l|c|c|c|c|c|c|c|}
\hline & Heat & \multicolumn{1}{c|}{ Cool } & DHW & Cook & Refrig. & Other ${ }^{(\mathrm{a})}$ & Total \\
\hline PG\&E & 92.32 & 81.35 & 10.23 & .16 & -- & 14.45 & 198.51 \\
\hline SCE & 46.44 & 121.48 & 9.02 & .12 & -- & 12.39 & 189.45 \\
\hline LADWP & 46.8 & 161.5 & 8.62 & .08 & -- & 11.27 & 228.27 \\
\hline BGP & 57.0 & 138.46 & 10.91 & .18 & 1.67 & 15.06 & 223.28 \\
\hline EPA/WSCC & 51.3 & 50.6 & 15.1 & 14.3 & -- & 5.4 & 136.7 \\
\hline CBECS & -- & -- & -- & -- & -- & -- & -- \\
\hline
\end{tabular}

(a) Defined as miscellaneous/other EUI. 
Table B.21. Hospital - Propane (kWh/ft'-yr)

\begin{tabular}{||l|c|c|c|c|c|c|c||}
\hline & Heat & Cool & DHW & Cook & Refrig. & Other ${ }^{(a)}$ & Total \\
\hline PG\&E & 23.34 & 92.91 & 30.26 & 1.31 & - & 33.97 & 181.79 \\
\hline SCE & 16.56 & 151.74 & 29.31 & 1.24 & -- & 33.32 & 232.17 \\
\hline LADWP & 5.62 & 109.11 & 26.41 & 1.08 & -- & 26.61 & 168.83 \\
\hline BGP & 14.93 & 183.47 & 29.6 & 1.28 & 7.47 & 33.31 & 270.06 \\
\hline EPA/WSCC & 166.1 & 21.8 & 35.1 & 2.7 & -- & 11.9 & 237.6 \\
\hline CBECS & -- & -- & -- & -- & -- & - & 133.6 \\
\hline (a) Defined as miscellaneous/other EUI. \\
\hline
\end{tabular}

Table B.22. Hotel/Motel - Propane ( $\left.\mathrm{kBtu} / \mathrm{ft}^{2}-\mathrm{yr}\right)$

\begin{tabular}{||l|c|c|c|c|c|c|c||}
\hline & Heat & Cool & DHW & Cook & Refrig. & Other ${ }^{(\mathrm{a})}$ & Total \\
\hline PG\&E & 51.42 & 34.27 & 9.75 & 3.15 & -- & 23.53 & 122.12 \\
\hline SCE & 34.43 & -- & 9.23 & 2.87 & - & 22.2 & 68.73 \\
\hline LADWP & 28.24 & -- & 7.94 & 2.84 & -- & 21.57 & 60.59 \\
\hline BGP & 30.76 & - & 10.06 & 3.11 & -- & 23.86 & 67.79 \\
\hline EPA/WSCC & 172.8 & 68.1 & 28.8 & 13.4 & -- & 6.0 & 289.1 \\
\hline CBECS & -- & -- & -- & - & -- & -- & 69.4 \\
\hline
\end{tabular}

(a) Defined as miscellaneous/other EUI. 
Table B.23. Miscellaneous - Propane (kBtu/ $\left.\mathrm{ft}^{2}-\mathrm{yr}\right)$

\begin{tabular}{||l|c|c|c|c|c|c|c||}
\hline & Heat & Cool & DHW & Cook & Refrig. & Other $^{(\mathrm{a})}$ & Total \\
\hline PG\&E & 38.37 & 74.94 & 6.54 & .61 & -- & 53.66 & 174.12 \\
\hline SCE & 22.57 & 89.81 & 5.61 & .52 & 1.98 & 48.92 & 169.41 \\
\hline LADWP & 19.46 & 96.17 & 5.44 & .51 & 1.99 & 50.72 & 174.29 \\
\hline BGP & 24.14 & 112.4 & 6.71 & .61 & 1.99 & 53.8 & 199.65 \\
\hline EPA/WSCC & 45.0 & 20.8 & 4.8 & 1.4 & -- & 3.5 & 75.5 \\
\hline CBECS & -- & -- & -- & -- & -- & -- & 60.7 \\
\hline (a) Defined as miscellaneous/other EUI. & & & & \\
\hline
\end{tabular}

Table B.24. Single Family Residence - Propane (kBtu/ $\left.\mathrm{ft}^{2}-\mathrm{yr}\right)$

\begin{tabular}{|c|c|c|c|c|c|c|c|c|c|c|c|}
\hline & Heat & Cool & Vent & DHW & Cook & Refrig. & $\begin{array}{l}\text { Int. } \\
\text { Lgt. }\end{array}$ & $\begin{array}{l}\text { Ext. } \\
\text { Lgt. }\end{array}$ & $\begin{array}{l}\text { Office } \\
\text { Equip. }\end{array}$ & Other & Total \\
\hline EPA/WSCC & 26.91 & -- & - & .16 & .06 & - & -- & -- & - & -- & 27.13 \\
\hline $\operatorname{RECS}^{(a)}$ & - & - & - & - & -- & - & - & - & - & - & 55.9 \\
\hline
\end{tabular}


Table B.25. Fort Irwin Initial Propane EUIs $\left(\mathrm{kBtu} / \mathrm{ft}^{2}-\mathrm{yr}\right)$

\begin{tabular}{|c|c|c|c|c|c|}
\hline Bldg Type & Total & Heat & DHW & Cooking & Other \\
\hline ADMIN & 35.56 & 36.10 & 1.33 & 0.00 & 0.00 \\
\hline ADMIN-MT & 0.00 & 33.00 & 1.33 & 0.00 & 0.00 \\
\hline BRK/ADM & 36.37 & 36.21 & 9.25 & 0.00 & 0.00 \\
\hline CHAPEL & 28.03 & 26.14 & 1.33 & 0.56 & 0.00 \\
\hline CLINIC & 88.13 & 45.31 & 15.00 & 0.56 & 27.82 \\
\hline CLUB & 145.91 & 9.18 & 14.84 & 106.04 & 15.85 \\
\hline COMCATN & 30.86 & 36.10 & 1.33 & 0.00 & 0.00 \\
\hline DET-RR & 3.04 & 10.00 & 6.08 & 0.00 & 0.00 \\
\hline DGR & 10.84 & 10.95 & 0.47 & 0.00 & 0.00 \\
\hline DINING & 145.91 & 9.18 & 14.84 & 106.04 & 15.85 \\
\hline FUELDSP & 26.14 & 26.14 & 0.00 & 0.00 & 0.00 \\
\hline GROCERY & 28.08 & 9.16 & 6.08 & 5.71 & 26.44 \\
\hline HANGAR & 26.60 & 26.14 & 0.47 & 0.00 & 0.00 \\
\hline HOSPITL & 104.79 & 45.31 & 30.14 & 1.52 & 27.82 \\
\hline HOTEL & 0.00 & 36.21 & 9.25 & 0.00 & 0.00 \\
\hline HSG-FAM & 42.54 & 26.91 & 11.00 & 5.50 & 0.00 \\
\hline HUT & 0.00 & 0.00 & 0.00 & 0.00 & 0.00 \\
\hline LAB-MED & 68.82 & 26.00 & 15.00 & 1.52 & 27.82 \\
\hline MTRPOOL & 20.87 & 26.14 & 1.33 & 0.00 & 0.00 \\
\hline MWR & 24.17 & 26.14 & 1.33 & 0.00 & 0.00 \\
\hline OTHER & 27.46 & 26.14 & 1.33 & 0.00 & 0.00 \\
\hline PLT-BLDG & 56.06 & 9.18 & 1.33 & 0.00 & 51.78 \\
\hline POOL-OT & 50.91 & 0.00 & 6.08 & 0.00 & 51.78 \\
\hline PUMP & 0.00 & 0.00 & 0.00 & 0.00 & 0.00 \\
\hline REC & 34.32 & 26.14 & 9.25 & 0.00 & 0.00 \\
\hline RESTRNT & 72.96 & 9.18 & 14.84 & 106.04 & 15.85 \\
\hline SECURTY & 26.64 & 26.14 & 1.33 & 0.00 & 0.00 \\
\hline
\end{tabular}


Table B.25. (contd)

\begin{tabular}{||l|r|r|r|r|r||}
\hline \multicolumn{1}{|c|}{ Bldg Type } & \multicolumn{1}{c|}{ Total } & \multicolumn{1}{c|}{ Heat } & DHW & Cooking & Other \\
\hline SHOP & 1.47 & 9.18 & 1.33 & 0.00 & 0.00 \\
\hline SHOP-AIR & 10.51 & 9.18 & 1.33 & 0.00 & 0.00 \\
\hline SHOP-ELC & 3.99 & 9.18 & 1.33 & 0.00 & 0.00 \\
\hline SHOP-HVY & 10.51 & 9.18 & 1.33 & 0.00 & 0.00 \\
\hline SHOP-WPN & 0.00 & 9.18 & 1.33 & 0.00 & 0.00 \\
\hline STOR-UH & 0.00 & 0.00 & 0.00 & 0.00 & 0.00 \\
\hline TRAING & 4.09 & 10.98 & 2.22 & 0.00 & 0.00 \\
\hline WHS & 6.24 & 9.18 & 0.88 & 0.00 & 0.00 \\
\hline WHS-CLD & 0.00 & 9.18 & 0.88 & 0.00 & 0.00 \\
\hline \hline
\end{tabular}


Table B.26. Fort Irwin Initial Electric EUI (kWh/ft'-year)

\begin{tabular}{|c|c|c|c|c|c|c|c|c|c|c|c|}
\hline Bldg. Type & Total & Heat & Cool & Vent & DHW & Cook & $\begin{array}{l}\text { Int. } \\
\text { Lgt. }\end{array}$ & $\begin{array}{l}\text { Ext. } \\
\text { Lgt. }\end{array}$ & Refrig. & $\begin{array}{l}\text { Office } \\
\text { Equip. }\end{array}$ & Other \\
\hline ADMIN & 9.86 & 0.60 & 1.50 & 1.22 & 0.21 & 0.10 & 5.00 & 1.00 & 0.24 & 2.92 & 0.50 \\
\hline ADMIN-MT & 16.68 & 0.60 & 3.89 & 1.22 & 0.21 & 0.10 & 6.00 & 1.00 & 0.24 & 2.92 & 0.50 \\
\hline BRK/ADM & 12.04 & 4.92 & 4.88 & 1.10 & 2.50 & 0.20 & 3.00 & 0.40 & 1.92 & 0.02 & 2.11 \\
\hline CHAPEL & 6.69 & 3.52 & 1.50 & 1.73 & 0.78 & 0.10 & 3.00 & 0.80 & 0.12 & 0.30 & 0.50 \\
\hline CLINIC & 27.96 & 3.15 & 9.44 & 2.33 & 7.82 & 0.10 & 9.59 & 1.00 & 0.57 & 3.28 & 6.85 \\
\hline CLUB & 35.72 & 0.30 & 5.97 & 6.32 & 1.00 & 4.60 & 3.00 & 1.00 & 10.54 & 0.04 & 4.26 \\
\hline COMCATN & 8.08 & 0.06 & 1.50 & 1.22 & 0.21 & 0.10 & 3.00 & 1.00 & 0.10 & 2.92 & 0.50 \\
\hline DET-RR & 4.91 & 3.52 & 1.50 & 1.73 & 0.78 & 0.10 & 2.00 & 0.80 & 0.00 & 0.00 & 0.00 \\
\hline DGR & 10.20 & 0.17 & 1.50 & 1.53 & 0.09 & 0.10 & 5.62 & 1.00 & 0.83 & 0.37 & 0.95 \\
\hline DINING & 41.62 & 2.01 & 5.97 & 6.32 & 1.00 & 4.60 & 7.14 & 2.67 & 10.54 & 0.04 & 4.26 \\
\hline FUELDSP & 1.18 & 3.52 & 1.50 & 1.73 & 0.78 & 0.10 & 3.00 & 0.80 & 0.00 & 0.00 & 0.00 \\
\hline GROCERY & 39.32 & 0.86 & 1.24 & 2.01 & 0.18 & 0.77 & 10.69 & 1.52 & 20.90 & 0.42 & 1.78 \\
\hline HANGAR & 3.30 & 3.52 & 1.50 & 1.73 & 0.78 & 0.10 & 3.00 & 0.80 & 0.10 & 0.30 & 0.50 \\
\hline HOSPITL & 37.34 & 3.15 & 9.44 & 6.32 & 7.82 & 0.30 & 9.59 & 1.00 & 0.57 & 3.28 & 6.85 \\
\hline HOTEL & 14.88 & 4.92 & 4.88 & 1.10 & 2.50 & 0.10 & 3.80 & 0.40 & 0.50 & 0.02 & 0.50 \\
\hline HSG-FAM & 6.91 & 4.18 & 4.88 & 1.10 & 2.50 & 0.58 & 3.80 & 0.40 & 1.92 & 0.02 & 2.11 \\
\hline HUT & 0.00 & 3.52 & 1.50 & 1.73 & 0.78 & 0.10 & 1.00 & 0.00 & 0.00 & 0.00 & 0.00 \\
\hline LAB-MED & 32.40 & 3.15 & 9.44 & 2.33 & 7.82 & 0.10 & 9.59 & 0.25 & 0.57 & 3.28 & 6.85 \\
\hline MTRPOOL & 7.77 & 3.52 & 1.50 & 1.73 & 0.78 & 0.10 & 3.00 & 0.80 & 0.10 & 0.10 & 0.93 \\
\hline MWR & 11.20 & 3.52 & 1.50 & 1.73 & 0.78 & 0.10 & 6.00 & 0.80 & 0.10 & 0.30 & 0.93 \\
\hline OTHER & 6.86 & 3.52 & 1.50 & 1.73 & 0.78 & 0.10 & 3.00 & 0.80 & 0.10 & 0.30 & 0.93 \\
\hline PLT-BLDG & 3.25 & 0.10 & 1.50 & 1.73 & 0.78 & 0.10 & 2.00 & 0.80 & 0.10 & 0.10 & 0.00 \\
\hline POOL-OT & 1.87 & 3.52 & 1.50 & 1.73 & 0.78 & 0.10 & 1.00 & 0.80 & 0.10 & 0.00 & 0.00 \\
\hline PUMP & 0.65 & 3.52 & 1.50 & 1.73 & 0.78 & 0.10 & 1.00 & 0.80 & 0.10 & 0.00 & 0.00 \\
\hline REC & 14.54 & 3.52 & 1.50 & 2.33 & 0.78 & 0.10 & 10.00 & 0.80 & 0.10 & 0.10 & 0.93 \\
\hline RESTRNT & 44.55 & 2.01 & 9.00 & 6.32 & 1.00 & 4.60 & 7.14 & 2.67 & 10.54 & 0.04 & 4.26 \\
\hline
\end{tabular}


Table B.26. (contd)

\begin{tabular}{|c|c|c|c|c|c|c|c|c|c|c|c|}
\hline Bldg. Type & Total & Heat & Cool & Vent & DHW & Cook & $\begin{array}{l}\text { Int. } \\
\text { Lgt. }\end{array}$ & $\begin{array}{l}\text { Ext. } \\
\text { Lgt. }\end{array}$ & Refrig. & $\begin{array}{l}\text { Office } \\
\text { Equip. }\end{array}$ & Other \\
\hline SECURTY & 14.19 & 0.10 & 1.50 & 1.22 & 0.21 & 0.10 & 6.00 & 1.43 & 0.24 & 1.00 & 2.72 \\
\hline SHOP & 6.55 & 0.10 & 1.50 & 1.73 & 0.78 & 0.10 & 2.00 & 0.80 & 0.10 & 0.10 & 0.93 \\
\hline SHOP-AIR & 6.16 & 0.1 & 1.5 & 1.73 & 0.78 & 0.1 & 2.00 & 0.8 & 0.1 & 0.1 & 0.93 \\
\hline SHOP-ELC & 6.58 & 0.10 & 1.50 & 1.73 & 0.78 & 0.10 & 2.00 & 0.80 & 0.10 & 0.10 & 0.93 \\
\hline SHOP-HVY & 6.16 & 0.1 & 1.5 & 1.73 & 0.78 & 0.1 & 2.00 & 0.8 & 0.1 & 0.1 & 0.93 \\
\hline SHOP-WPN & 7.04 & 0.10 & 1.50 & 1.73 & 0.78 & 0.10 & 2.00 & 0.80 & 0.10 & 0.10 & 0.93 \\
\hline STOR-UH & 0.12 & 0.19 & 0.00 & 0.68 & 0.06 & 0.00 & 1.00 & 0.19 & 0.00 & 0.00 & 0.00 \\
\hline TRAING & 7.22 & 0.10 & 3.00 & 0.83 & 0.53 & 0.10 & 2.85 & 0.70 & 0.10 & 0.10 & 0.00 \\
\hline WHS & 2.95 & 0.10 & 0.94 & 0.68 & 0.06 & 0.00 & 2.00 & 0.19 & 0.10 & 0.10 & 0.50 \\
\hline WHS-CLD & 48.85 & 0.10 & 0.94 & 0.68 & 0.06 & 0.00 & 2.00 & 0.19 & 1.50 & 0.10 & 0.50 \\
\hline
\end{tabular}


Appendix C

Building Numbers by Building Type 


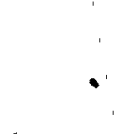




\section{Appendix C}

\section{Building Numbers by Building Type}

Building Type Building Numbers

ADMIN

$00011,00100,00101,00130,00152,00154,00157,00158,00236,00237,00241$, $00243,00248,00255,00256,00257,00258,00279,00281,00316,00320,00365$, $00372,00383,00385,00408,00411,00415,00425,00426,00428,00429,00433$, 00436, 00437, 00439, 00441, 00442, 00443, 00444, 00445, 00451, 00452, 00453, 00454, 00458, 00464, 00466, 00479, 00483, 00488, 00497, 00498, 00499, 00504, $00506,00508,00510,00513,00520,00521,00524,00526,00527,00528,00529$, 00539, 00543, 00544, 00549, 00551, 00554, 00564, 00570, 00578, 00579, 00580, 00583, 00587, 00604, 00615, 00813, 00826, 00828, 00930, 00983, 00985, 00988, $06201,06252,07600$

ADMIN-MT 00136, 00156, 00182, 00230, 00239, 00402, 00500, 00502, 00503, 00505, 00507, $00546,00548,00550,00561,00563,00565,00566,00567,00569,00571,00573$, $00575,00577,00582,00590,00591,00592,00593,00594,00595,00596,00597$, 00598, 00599, 00653, 00654, 00655, 00656, 00657, 00658, 00662, 00867, 00931, 00932, 00933, 00940

BRK/ADM $\quad 00014,00028,00098,00099,00102,00103,00104,00105,00106,00107,00108$, $00110,00111,00226,00249,00250,00251,00252,00261,00262,00264,00265$, $00267,00273,00275,00412,00413,00414,00416,00417,00418,00419,00420$, $00421,00422,00423,00434,00440,00448,00487,00489,00491,00493,00494$, $00511,00512,00514,00516,00518,00519,00523,00530,00534,00540$

CHAPEL $\quad 00212,00233,00315$

CLINIC $\quad 00171,00235,00242,00245,00478$

CLUB $\quad 00021,00037,00202,20018$

COMCATN $\quad 00013,05005,05006,06202,06212,06220,06230,06250,16150$

DET-RR $\quad 00629,00670,04605,04820,04920,06017,06032,06047,06057,06550,07632$, $11013,12006,70223,70310,70443,70504,70604,70606,70615,70773,70915$, $71020,71103,71610,71720,72115$

DGR $\quad 00034,00308,00317,00404,00430,00909,00918$

DINING $\quad 00222,00254,00431,00447,00449,00468,00476,00535,00560,06012,06013$, $06027,06028,06042,06043,06058,06059,11012,12002,70311,70616$

FUELDSP $\quad 00355,00622,00624,00627,00640,00643,00647,00683,00685,00686,00687$, 00689, 00690, 00691, 00834, 00836, 00852, 00871, 00872, 00874, 00877, 00878, 00890, 00950, 06205, 07702, 07704, 07705, 07706, 07707, 07708, DIOSF, MOGAS 
GROCERY 00920

HANGAR 06203

HOSPITL $\quad 00166$

HOTEL $\quad 00900,00901,00902,00903,00904,00906$, TS001, TS003, TS004, TS005, TS036, TS046, TS047, TS048, TS049, TS050

HSG-FAM $\quad 00001,01716,01718,01720,01722,01824,01826,01828,01830,01832,01834$, 01836, 01838, 01839, 01841, 01842, 01843, 01844, 01900, 01901, 01902, 01903, 01904, 01905, 01906, 01907, 01908, 01909, 02000, 02001, 02002, 02003, 02004, 02005, 02006, 02008, 02009, 02010, 02012, 02100, 02101, 02102, 02103, 02104, 02105, 02106, 02107, 02108, 02109, 02110, 02111, 02207, 02209, 02300, 02301, 02302, 02303, 02304, 02305, 02306, 02307, 02308, 02310, 02312, 02313, 02314, 02400, 02401, 02402, 02403, 02404, 02405, 02406, 02407, 02408, 02409, 02410, 02411, 02412, 02413, 02414, 02415, 02416, 02417, 02418, 02419, 02420, 02421, 02422, 02424, 02426, 02428, 02430, 02502, 02503, 02504, 02506, 02507, 02508, 02600, 02601, 02602, 02603, 02604, 02605, 02606, 02607, 02608, 02609, 02610, 02611, 02612, 02613, 02614, 02615, 02616, 02617, 02618, 02619, 02620, 02621, 02703, 02704, 02705, 02707, 02709, 02711, 02713, 02714, 02800, 02801, 02803, 02804, 02805, 02806, 02807, 02808, 02809, 02810, 02811, 02812, 02813, 02814, 02815, 02816, 02817, 02818, 02819, 02820, 02821, 02822, 02824, 02900, 02902, 02903, 02904, 02906, 02908, 02910, 03000, 03001, 03002, 03003, 03005, 03006, 03007, 03008, 03009, 03010, 03011, 03012, 03013, 03014, 03015, 03101, 03102, 03103, 03104, 03105, 03106, 03200, 03201, 03202, 03204, 03206, 03208, 03302, 03304, 03306, 03308, 03309, 03310, 03311, 03312, 03313, 03314, 03316, 03317, 03318, 03319,03320,03321, 03322, 03323, 03324, 03325, 03326, 03328, 03401, 03402, 03403, 03404, 03405, 03406, 03407, 03408, 03409,03410, 03412, 03414, 03415, 03416, 03417, 03418, 03419,03420, 03421, 03422, 03500, 03501, 03502, 03503, 03504, 03505, 03506, 03507, 03508, 03509, 03510, 03511, 03512, 03513, $03514,03515,03516,03517,03518,03519,03520,03521,03522,03523,03524$, 03600, 03601, 03602, 03603, 03604, 03605, 03606, 03607, 03608, 03609, 03610, 03611, 03612, 03613, 03614, 03615, 03616, 03617, 03618, 03619,03620,03621, 03622, 03623, 03624, 03625, 03626, 03627, 03628, 03629, 03630, 03631, 03632, 03633, 03634, 03635, 03636, 03637, 03901, 03902, 03903, 03904, 03905, 03906, 03907, 03908, 03909, 03910, 03911, 03912, 03913, 03914, 03915, 03916, 03917, 03918, 03919, 03920, 03921, 03922, 03923, 03924, 03925, 03926, 03930, 03931, 03932, 03933, 03934, 03935, 03936, 03937, 03938, 03939, 03940, 03941, 03942, 03943, 03944, 03945, 03946, 03948, 03950, 03951, 03952, 03953, 03954, 03955, 03956, 03957, 03958, 03959, 03960, 03961, 03962, 03963, 03964, 03966, 03967, 03968, 03969, 03970, 03971, 03972, 03973, 03974, 03975, 03976, 03977, 03978, 03979, 03980, 03981, 03982, 03983, 03984, 03985, 03986, 03987, 03988, 03989, 03991, 03992, 03994, 03996, 03997, 03998, 03999, 04001, 04002, 04003, 04005, 04007, 04008, 04009, 04010, 04011, 04012, 04013, 04014, 04015, 04016, 04017, 04018, 04019, 04020, 04021, 04022, 04024, 04025, 04026, 04027, 04028, 04029, 04031, 04032, 04033, 04034, 04035, 04036, 04037, 04038, 04039, 04040, 04041, 04042, 04043, 04044, 04045, 04046, 04047, 04048, 04049, 04050, 04051, 04052, 04053, 04054, 04055, 04058, 04059, 04060, 04061, 04062, 04063, 04064, 04065, 04066, 04067, 04070, 04071, 04072, 04073, 04074, 04075, 04076, 04077, 04078, 04079, 04080, 04081, 04082, 04083, 04084, 04086, 04087, 04088, 04089, 04090, 04091, 04092, 04093, 04094, 04095, 04096, 04097, 04098, 04099, 05010, 05011, 
05015, 05016, 05017, 05018, 05019, 05020, 05021, 05022, 05023, 05024, 05025, 05026, 05027, 05028, 05029, 05030, 05031, 05032, 05034, 05035, 05036, 05037, 05038, 05039, 05040, 05043, 05044, 05045, 05046, 05047, 05048, 05049, 05050, 05051, 05052, 05053, 05055, 05056, 05057, 05058, 05059, 05060, 05061, 05062, 05063, 05064, 05065, 05068, 05069, 05070, 05071, 05072, 05073, 05074, 05075, 05076, 05079, 05080, 05081, 05082, 05083, 05084, 05085, 05086, 05087, 05088, 05089, 05090, 05091, 05092, 05093, 05094, 05095, 05096, 05097, 05098, 05099, 05100, 05101, 05102, 05103, 05104, 05105, 05106, 05107, 05108, 05109, 05110, $05111,05114,05115,05116,05117,05118,05119,05120,05121,05122,05123$, 05124, 05126, 05127, 05128, 05129, 05132, 05133, 05134, 05135, 05136, 05137, $05138,05139,05140,05141,05142,05143,05144,05145,05146,05147$

HSG-FAM(334) 03680, 03681, 03682, 03683, 03684, 03685, 03687, 03689, 03690, 03691, 03692, 03693, 03694, 03695, 03697, 03699, 03700, 03701, 03702, 03703, 03704, 03705, 03707, 03709, 03711, 03712, 03713, 03714, 03715, 03716, 03717, 03718, 03720, 03721, 03722, 03723, 03724, 03725, 03726, 03727, 03728, 03730, 03731, 03732, 03733, 03735, 03737, 03738, 03739, 03740, 03741, 03742, 03743, 03744, 03745, 03746, 03747, 03748, 03749, 03750, 03751, 03752, 03800, 03801, 03802, 03803, 03804, 03805, 03806, 03807, 03809, 03811, 03812, 03813, 03814, 03815, 03816, 03818, 03820, 03821, 03822, 03823, 03824, 03825, 03826, 03827, 03828, 03829, $03831,03832,03833,03834,03835,03837,03839,03840,03841,03842,03843$, $03844,03845,03846,03848,03850,03851,03852,03853,03854,03855,03856$, $03857,03858,03860,03861,03862,03863,03864,03865,03866,03867,03868$, $03869,03870,03871,03872,03880,03881,03882,03883,03884,03885,03886$, 03890, 03891, 03893, 03895, 03897, 03898

HUT $\quad 00334,00628,01319,06000,06001,06002,06003,06004,06005,06006,06007$, 06008, 06009, 06010, 06011, 06014, 06015, 06016, 06018, 06019, 06020, 06021, 06022, 06023, 06024, 06025, 06026, 06029, 06030, 06031, 06033, 06034, 06035, 06036, 06037, 06038, 06039, 06040, 06041, 06044, 06045, 06046, 06048, 06049, 06050, 06051, 06052, 06053, 06054, 06055, 06056, 06060, 06061, 06062, 06063, 06064, 06065, 06066, 06067, 06068, 06069, 06070,06071, 06100,06300, 11006, 11008, 12008, 70224, 70309, 70312, 70444, 70501, 70614, 70774, 70884, 71102, 71710,71850

KITCHEN $\quad 00819$

LAB-MED $\quad 00144,00228$

MTRPOOL $\quad 00600,00605,00608,00612,00614,00620,00621,00623,00626,00631,00632$, $00633,00634,00635,00639, .00642,00646,00650,00665,00666,00667,00668$, $00669,00680,00681,00825,00829,00830,00832,00835,00837,00840,00847$, 00850, 00857, 00873, 00879, 00941, 00945

MWR $\quad 00009,00023,00124,00310,00312,00331,00340,00361,00410,00480,00556$, 00671, 00672, 00673, 00675, 00676, 00677, 00770, 00910, 00911, 00976, 01209, $01210,01300,01313,01318,01322,03995$

OTHER 00992, WASTO

PLT-BLDG $\quad 00012,00109,00169,00244,00253,00263,00343,00432,00450,00532,00617$, 00853, 00984, 07703, 16152, 19000, 20003 


\begin{abstract}
PLT-EQP $\quad 00849,05991$, DXFMR, TRFMR
POOL-OT $\quad 00017,00018,00020,00325,00327,00328$

PRDCTN $\quad 00730$

PUMP $\quad 00027,00042,00043,00044,00143,00149,00319,00324,00339,00353,00388$, $00630,00636,00638,00641,00652,00663,00679,00682,00700,00705,00708$, $00709,00824,00838,00848,00851,00870,00876,00880,00974,04006,05990$, 06204,20020
\end{abstract}

REC $\quad 00322,00338,00362,00905$

RESTRNT $\quad 00323,00975$

SECURTY $\quad 00010,00326,00400,00427,00688,00692,07631,07700,20010$

SHOP $\quad 00356,00357,00367,00384,00501,00568,00664,00842,00846$, HDSDS, HDSDT, MOWEL

SHOP-ELC $\quad 00581,00616,00855,00859$

SHOP-WPN 07602

STOR-UH $\quad 00015,00148,01824,01826,01828,01830,01832,01834,01836,01838,01839$, $01841,01842,01843,01844,02000,02002,02004,02006,02008,02010,02012$, 02100, 02101, 02102, 02103, 02104, 02105, 02106, 02107, 02108, 02109, 02110, 02111, 02207, 02209, 02300, 02301, 02302, 02303, 02304, 02305, 02306, 02307, 02308, 02310, 02312, 02313, 02314, 02400, 02401, 02402, 02403, 02404, 02405, 02406, 02407, 02408, 02409, 02410, 02411, 02412, 02413, 02414, 02415, 02416, $02417,02418,02419,02420,02421,02422,02424,02426,02428,02430,02502$, 02503, 02504, 02506, 02507, 02508, 02600, 02601, 02602, 02603, 02604, 02605, 02606, 02607, 02608, 02609, 02610, 02611, 02612, 02613, 02614, 02615, 02616, 02617, 02618, 02619, 02620, 02621, 02703, 02704, 02705, 02707, 02709, 02711, 02713, 02714, 02800, 02801, 02803, 02804, 02805, 02806, 02807, 02808, 02809, $02810,02811,02812,02813,02814,02815,02816,02817,02818,02819,02820$, 02821, 02822, 02824, 02900, 02902, 02903, 02904, 02906, 02908, 02910, 07606, 07607, 07608, 07609, 07610, 07611, 07612, 07613, 07614, 07615, 07616, 07617, $07618,07619,07620,07621,07622,07623,07624,07625,07626,07627$

TRAING

$00184,00217,00284,00285,00286,00490,00492,00496,00547,00588,01201$, 01202, 01203, 01204, 01205, 01206, 01207, 01208, 11010, 12010, 70445, 70775 
WHS

$00022,00024,00139,00234,00277,00306,00318,00333,00342,00344,00352$, 00354, 00358, 00359, 00360, 00364, 00386, 00435, 00456, 00460, 00462, 00470, $00472,00474,00485,00486,00517,00531,00537,00545,00552,00558$, 00562,00584, 00585, 00586, 00609, 00625, 00703, 00706, 00814, 00818, 00821, 00827, 00844, 00860, 00861, 00863, 00888, 00934, 04101, 04102, 04103, 04104, 04105, 04106, 04107, 04108, 04109, 04110, 04111, 04201, 04202, 04203, 04204, 04205, 04206, 04207, 04208, 04209, 04210, 04211, 04301, 04302, 04303, 04304, 04305, 04306, 04307, 04308, 04309, 04310, 04401, 04402, 04403, 04404, 07601, 07701, 20001, 20005, 20008

WHS-CLD $\quad 00862$ 


\section{Distribution}

No. of

Copies

\section{OFFSITE}

12 DOE/Office of Scientific and Technical Information

2 M. Ginsberg

Federal Energy Management Program

U.S. Department of Energy EE-44

1000 Independence Avenue, S.W.

Washington, DC 20585

2 L. Harris

Federal Energy Management

Program

U.S. Department of Energy

E-44

1000 Independence Avenue, S.W.

Washington, DC 20585

V. Petrolati

DOE/In-House Energy Management

U.S. Department of Energy

FM-33

1000 Independence Avenue, S.W.

Washington, DC 20585

2 A. Gillespie

FORSCOM

Attn: FCEN-RDF

Building 200

Fort McPherson, GA 30330-6000

D. Fournier

U.S. Corps of Engineers

Construction Engineering

Research Laboratory

P.O. Box 4005

Champaign, IL 61820-1305
No. of

Copies

$5 \quad$ B. Starling

U.S. Corps of Engineers

Engineering Division

Attn: CEHND-PM-CR

P.O. Box 1600

Huntsville, AL 35807-4301

3 Commander

National Training Center

Directorate of Public Works

Attn: Rene Quinones

AFZT-DPW-MO

Fort Irwin, CA 92310-5000

\section{$\underline{\text { ONSITE }}$}

DOE Richland Operations Office

D. D. Green

(K8-50)

29 Pacific Northwest Laboratory

P. R. Armstrong

(K5-08)

A. L. Dittmer

(K5-08)

J. W. Currie

(K8-54)

J. A. Dirks

(K8-18)

D. R. Dixon (2)

(K8-17)

D. L. Hadley (3)

(K5-08)

J. M. Keller

(K5-08)

K. L. McMordie

(K5-08)

S. A. Parker

(K5-08)

G. B. Parker (3)

(K8-54)

D. R. Payson

(K7-90)

E. E. Richman

(K5-08)

W. F. Sandusky

(K5-06)

S. A. Shankle

(K8-15)

D. J. Stucky

Distr. 1 
PNL-9065 Vol. 2

UC-350

No. of

Copies

R. R. Wahlstrom

(K5-08)

Project File (2)

Publishing Coordination

Technical Report Files (5)

Distr.2 